\title{
A MATA ATLÂNTICA dO ESTADO DE SÃO PAULO ATRAVÉS DE UM PROGRAMA DE MULTIMÍDIA
}

\section{KLAUS DUARTE BARRETTO}

Engenheiro Florestal

\section{Orientador:Prof. Dr. HILTON THADEU ZARATE DO COUTO}

Dissertação apresentada a Escola Superior de Agricultura "Luiz de Queiroz", Universidade de São Paulo, para obtenção do título de Mestre em Ciências, Área de Concentração: Ciências Florestais

\section{PIRACICABA}

Estado de São Paulo - Brasil

Julho -1997 
Dados Internacionais de Catalogação na Publicação (CIP) DIVISÃo DE BIBLIOTECA E DOCUMENTAÇÃO - Campus "Luiz de Queiroz"/USP

\author{
Barretto, Klaus Duarte \\ A Mata Atlântica do estado de São Paulo através de um programa de multimidia / \\ Klaus Duarte Barreto. - - Piracicaba, 1997. \\ 132 p. : il. \\ Dissertação (mestrado) - - Escola Superior de Agricultura Luiz de Queiroz, 1997. \\ Bibliografia. \\ 1. Educação ambiental 2. Mata Atlântica 3. Multimidia I. Titulo
}

CDD 333.707 


\section{A MATA ATLÂNTICA DO ESTADO DE SÃO PAULO ATRAVÉS DE UM PROGRAMA DE MULTIMÍDIA}

\section{KLAUS DUARTE BARRETTO}

Aprovada em: 08. 09. 1997

Comissão Julgadora:

Prof. Dr. Hilton Thadeu Zarate do Couto

ESALQ/USP

Prof. Dr. Marcos Sorrentino

ESALQ/USP

Prof. Dr. Alexander Jofeph Romiszowski

Escola do Futuro/USP

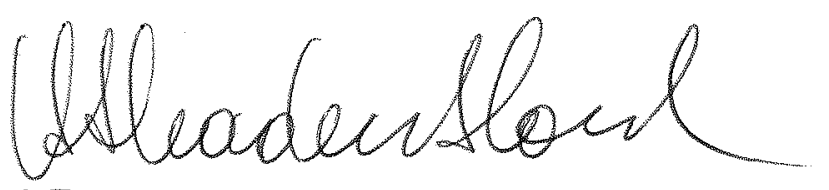

Prof. Dr. Hilton Thadeu Zarate do Couto Orientador 


\section{AGRADECIMENTOS}

A toda minha família pelo apoio.

A CAPES pela bolsa oferecida.

Ao Departamento de Ciências Florestais por possibilitar minha entrada no mestrado.

Ao Prof. Thadeu, por me aceitar como orientando, dando apoio e acreditando num trabalho novo e incerto para todos nós.

Ao Prof. Marcos que sempre tem acendido luzes em minha formação.

Ao Prof. Marcelo que me mostrou as primeiras possibilidades da multimídia.

A turma da PG, pelo período de convivência, onde compartilhamos as idéias, os trabalhos, as alegrias, a falta de dinheiro e a esperança.

À Mônica pelo grande apoio e estímulo.

À Ciça, pelas valiosas sugestões e apoio na coleta de dados e revisão deste trabalho. Ao Delmar, Leandro, Alexander, e a toda a equipe de multimídia da Escola do Futuro, por discutirem meu projeto e me auxiliarem na resolução dos problemas na montagem do protótipo do CD-ROM.

A $3 \mathrm{M}$ do Brasil em Sumaré que acreditou neste projeto e doou verba para seu desenvolvimento.

Aos alunos e à direção do Colégio Anglo de Itapira e Campinas por possibilitarem a pesquisa, e sugerirem importantes idéias para a complementação do CD-ROM

$\mathrm{E}$ a todos vocês que me apoiaram neste trabalho, meu muito obrigado. 


\section{SUMÁRIO}

Páginas

LISTA DE FIGURAS....................................................................... iv

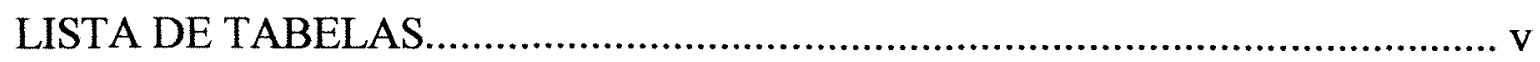

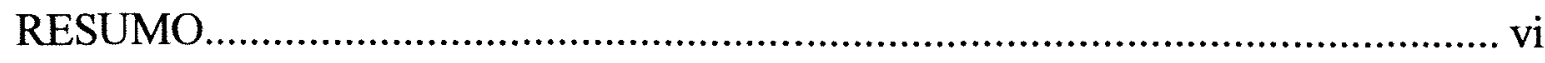

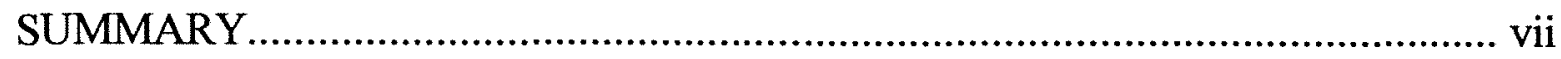

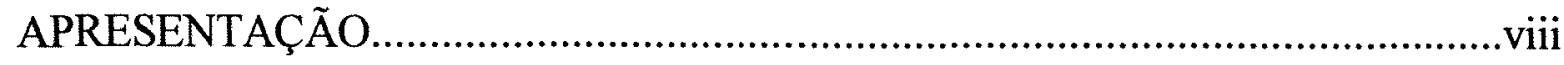

1 INTRODUÇÃO ........................................................................... 1

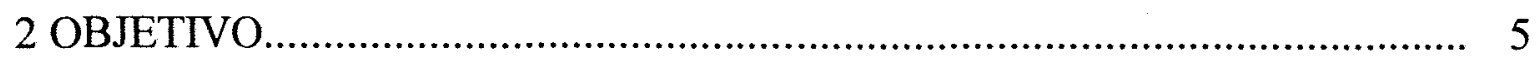

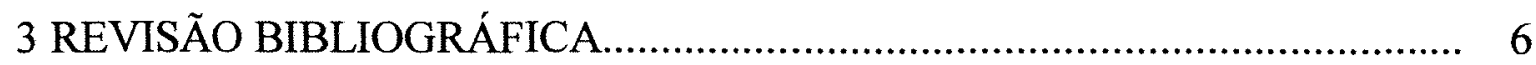

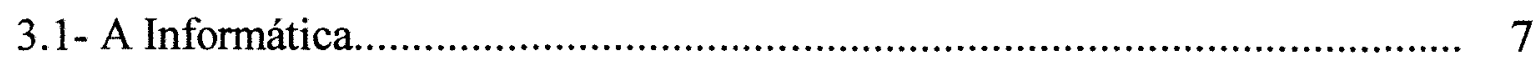

3.1.1- A Informática na Educação................................................................. 7

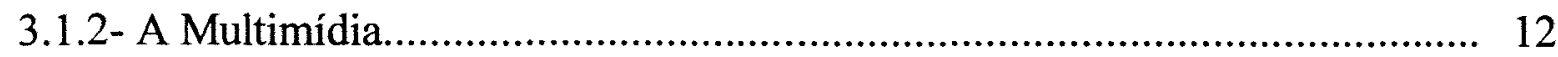

3.2- A Educação Ambiental e Materiais Didáticos............................................... 16

3.3- A Vegetação da Mata Atlântica...................................................................... 23

3.3.1- Mata de Encosta................................................................................ 26

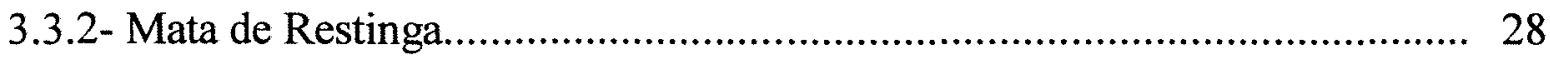

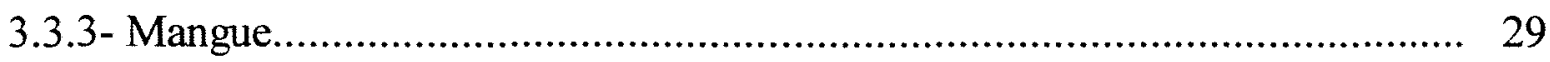

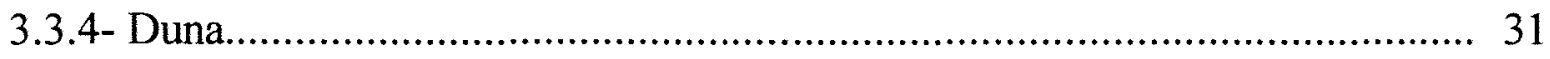

3.4- Ocupação da Mata Atlântica......................................................................... 32

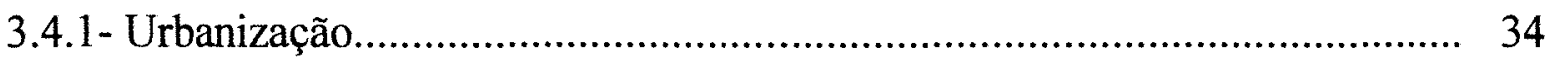

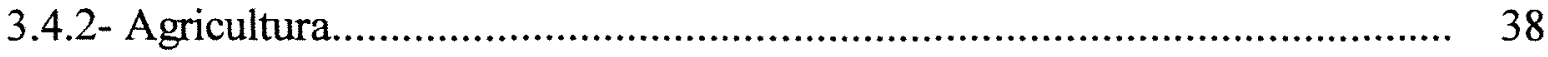

3.4.3- Populações Tradicionais..................................................................... 39

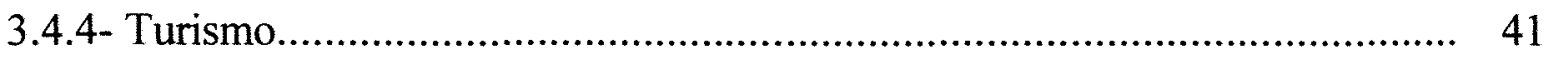

3.5- Conservação e Recuperação da Mata Atlântica............................................. 45

3.5.1- Unidades de Conservação........................................................................ 45

3.5.2- Pesquisas na Mata Atlântica.................................................................... 49

3.5.3- Legislação Ambiental.......................................................................... 50 
4 MATERIAIS E MÉTODOS................................................................. 54

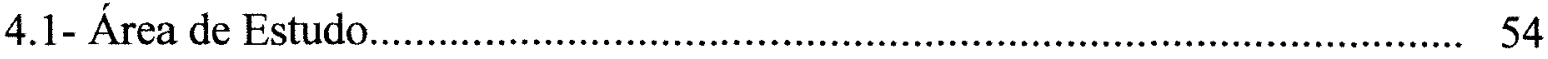

4.2- Metodologia de Trabalho......................................................................... 55

4.3- Fases do Trabalho................................................................................. 56

4.3.1- O estudo de Multimídia...................................................................... 57

4.3.2- Definição de público alvo................................................................... 57

4.3.3- Aplicação do questionário........................................................................ 58

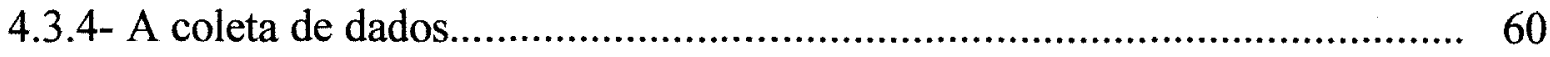

4.3.5- O processamento dos dados.................................................................. 60

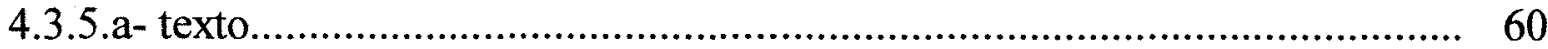

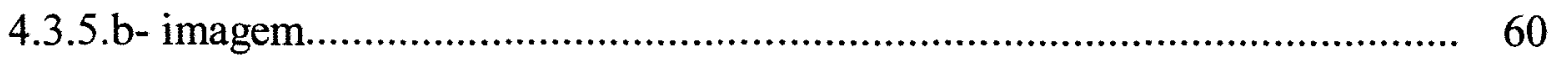

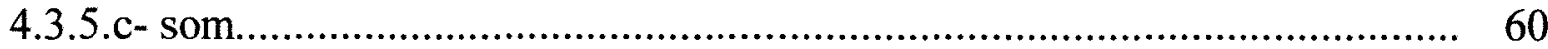

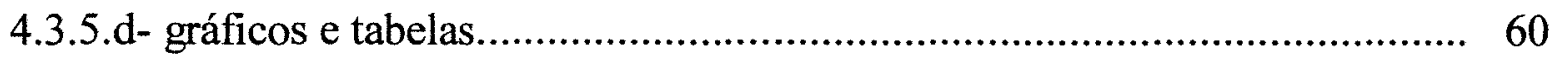

4.3.5.e- aplicativo de multimídia.................................................................... 61

4.3.6- A elaboração do protótipo de CD-ROM da Mata Atlântica....................... 61

4.3.7- A utilização do protótipo........................................................................ 63

4.3.8- Aplicação do desafio................................................................................. 64

5 RESULTADOS E DISCUSSÕES........................................................... 66

5.1- Resultados da aplicação dos questionários.................................................... 66

5.2- Resultados da aplicação do protótipo......................................................... 73

5.3- Resultados da aplicação do desafio............................................................ 78

6 CONSIDERAÇÕES FINAIS................................................................. 83

6.1- Ensino e educação....................................................................................... 83

6.2- Dinâmica de desenvolvimento................................................................. 84

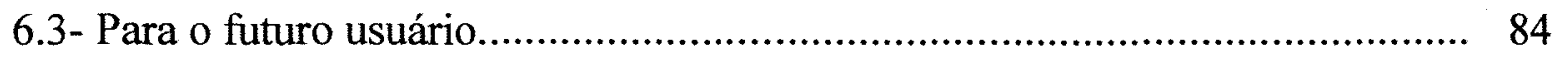

6.4- As etapas necessárias de elaboração de um multimídia.................................. 85

7 PERSPECTIVA FUTURA....................................................................... 88

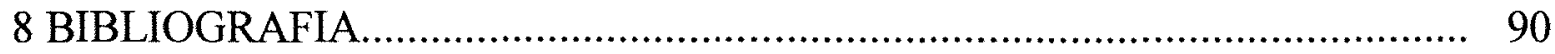




\section{LISTA DE FIGURAS}

Página

1 Aplicação do protótipo para a classe...................................................... 75

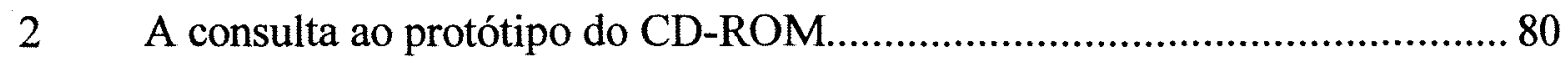

3 Resultado da resolução do desafio (mapa esquemático)............................. 80 


\section{LISTA DE TABELAS}

Página

$1 \quad$ Número de registro de material de educação ambiental por Estado........... 19

$2 \quad$ Número de registro em educação ambiental por tipo de material............... 20

3 Número de registro de material em educação ambiental por tipo de entidade que produziu..................................................................................................... 20

4 Área dos remanescentes florestais do domínio da Mata Atlântica, desmatamento e incrementos entre 1985 e1990.

5 Vegetação do Litoral do Estado de São Paulo (1990/92)..............................

6 Ocorrência das espécies, gêneros e famílias, por Região, nas 63 localidades amostradas de Mata Atlântica. utilizado os taxons identificados até espécies.................................................................................

7 Teor de matéria orgânica (M.O.),umidade (U) e matéria inorgânica (M.I.) nos solos de Mangue e Dunas.

8 Distribuição da população urbana e rural em diferentes municípios da região do litoral do estado de São Paulo.

9 Distribuição das áreas naturais protegidas do estado de São Paulo..............

10 Resultado da aplicação de questionário sobre a Mata Atlântica aos alunos de $1^{0}$ grau, em uma escola na cidade de Itapira-SP

11 Resultado da aplicação de questionário sobre a Mata Atlântica aos alunos de $2^{0}$ grau, em duas escolas nas cidades de Campinas e Itapira-SP.

12 Resultado da aplicação do questionário a 5 professores do Colégio Anglo de Itapira-SP. 


\title{
A MATA ATLÂNTICA do ESTADO DE SÃo PAULO ATRAVÉS DE UM PROGRAMA DE MULTIMÍDIA
}

\author{
Autor:KLAUS DUARTE BARRETTO \\ Orientador:Prof. Dr. HILTON THADEU ZARATE DO COUTO
}

\section{RESUMO}

O presente trabalho teve como objetivo desenvolver um protótipo de CDROM sobre a região litorânea da Mata Atlântica do Estado de São Paulo, abordando diversos tópicos como: localização e mapas, vegetação, ocupação, conservação e recuperação e um banco de informações, utilizando o programa Tool Book 4.0. Esse protótipo baseou-se em um roteiro inicial, o qual foi complementado com subsídios colhidos junto aos alunos de $7^{0}$ série do $1^{0}$ grau ao $2^{0}$ colegial e professores, de forma a potencializar as expectativas e interesses, do público alvo.

Pode-se destacar como fundamental a participação de professores e alunos no processo de análise e sugestões sobre os tópicos: sistema de navegação e jogos do CD-ROM, isso possibilitou colher valiosas informações para estruturação e futura finalização do CD-ROM de forma a atingir seu objetivo. 


\title{
THE ATLANTIC FOREST THE STATE OF SÃO PAULO THROUGH A MULTIMEDIA PROGRAM
}

\author{
Author:KLAUS DUARTE BARRETTO \\ Advisor:Prof. Dr. HILTON THADEU ZARATE DO COUTO
}

\section{SUMMARY}

The present work deals with the development of a CD ROM prototype about the coast region, of the Atlantic Forest in São Paulo state including topics, such as: localization, maps, vegetation, ocupation, conservation and recuperation, databook, using the computer software Tool Book 4.0. This prototype is based on an inicial screenplay, which was complemented with informotion given by from studens with ages varying from 13 to 17 years old, and teachers. This information entranced the potential of this work for meeting the expectations of target people.

It was important the participation of the teachers and student for the process of analysis to choose the navegation process and for the suggestions for the games to be included in CD ROM. 


\section{APRESENTAÇÃO}

\section{Histórico de elaboração do trabalho}

Após ter sido aprovado para o curso de mestrado no Departamento de Ciências Florestais, com a proposta de projeto sobre "fragmentos florestais", já no primeiro mês me veio uma certa inquietação. Nos vários anos de minha formação acadêmica e posterior trabalho, enquanto profissional, meus interesses foram diversos: diagnóstico e manejo de áreas naturais, unidades de conservação, educação ambiental, paisagismo, fotografia e artes plásticas. Dentro dessas várias possibilidades a grande certeza que tive em todos esses anos: a área ambiental era o caminho para minha realização pessoal e profissional, principalmente, quando relacionado com comunidades na busca da melhoria da qualidade de vida.

$\mathrm{E}$ assim foi. Acabei mudando meu projeto de mestrado, para uma coisa nova, fascinante, que pouco conhecia, desenvolvimento de um programa de multimídia ambiental.

No Brasil a multimídia começava a ganhar força, a atuação estava restrita a grupos de empresas que desenvolviam programas, publicitários, a maioria sem objetivo educacional. As multimídias existentes no mercado na forma de CD-ROM, eram importadas e pouco relacionadas às questões ambientais. $\mathrm{Na}$ Universidade era algo que engatinhava, devido a falta de equipamentos e conhecimento. Já na ESALQ, isso era mais evidente, pois a linha de trabalho e pesquisa estavam distantes da multimídia.

Assim meu projeto de mestrado passou a se chamar: "A Mata Atlântica do Estado de São Paulo Através de um Programa de Multimídia". O objetivo foi unir meus interesses e experiências, tentando criar algo, que não ficasse apenas na biblioteca da Universidade, mas que pudesse ser utilizado e contribuísse no ensino das questões ambientais nas escolas e comunidade em geral.

Até aquele momento tinha conhecido alguns CD-ROM. Meu interesse era milhares de vezes superior ao conhecimento que deveria ter para elaboração de um 
CD-ROM. Essa constatação se deu ao longo do processo de realização dessa dissertação. $\mathrm{Na}$ época nem computador eu tinha, mas a vontade era o que me motivava e assim assumi o desafio.

Comecei a procurar informações, e encontrei um curso de multimídia no Departamento de Multimeios da Universidade de Campinas (UNICAMP). Era o que precisava no momento, conhecer um pouco mais das possibilidades da multimídia e ter contato com um programa de autoria (criação), desenvolvido por um professor do Departamento.

Veio então a necessidade de recursos para compra de equipamento, viagens para coleta de dados, etc. Como a idéia do projeto era atual, achei que não teria grandes dificuldades em conseguir financiamento junto a empresas. Doce ilusão. Foram longos meses de telefonemas, viagens, reuniões, cartas, para mais de trinta empresas de grande porte e com interesse na área ambiental. Mesmo com todo esforço, consegui apenas uma doação da $3 \mathrm{M}$ do Brasil de $\mathrm{R} \$ 3.000,00$. Com esse recurso foi possível comprar um Kit multimídia, e fazer duas viagens ao litoral para fotografar elementos relativos a Mata Atlântica.

No programa que seria desenvolvido, queria valorizar a imagem, onde os textos e som viriam como complementares, tornando-o mais dinâmico e interessante para o público jovem.

Apesar das várias dificuldades, houve um ponto importante, que minimizou a falta de financiamento para o desenvolvimento do trabalho: foi meu grande interesse pela fotografia. Há vários anos venho fotografando o litoral (em cromo/slides), e na época possuía um banco de imagens com cerca de 2.000 cromos. Mas ainda assim, para o trabalho a que me propunha era necessário incrementar o banco, de forma a abordar os diversos temas e ter opções de escolha.

A vantagem em possuirmos nosso próprio banco de imagens (foto, vídeo) e som é a facilidade de acesso além de se evitar problemas com os direitos autorais.

O erro na captação de recursos, talvez, tenha ocorrido devido ao período em que a maioria das empresas estava cortando os gastos. Sendo assim, o modelo de 
projeto enviado às empresas deveria ter sido mais objetivo, com poucas páginas, e talvez com um protótipo do CD-ROM para ser apresentado. O fator último e talvez o mais grave, para a não captação de recursos, foi não ter enviado o projeto para entidades financiadoras nacionais e internacionais, por achar que a liberação de verbas dentro das empresas seria mais fácil e rápida.

Para contornar o problema da falta de dinheiro necessário ao desenvolvimento do projeto, investi com recursos próprios para melhorar meu computador que hoje é apenas um 486 DX 100 16MG RAM/ HD 1200MG, mas o suficiente para a montagem de um protótipo. Também comprei um scanner de slides, pois sem ele seria impossível o trabalho. Os gastos com várias viagens para coletas de imagens no litoral, foram financiados pelo Departamento de Ciências Florestais/ESALQ.

$\mathrm{O}$ primeiro orçamento do projeto estava em R\$25.000,00 o qual incluía alguns equipamentos, viagens e material de consumo. Com o passar do tempo, à medida em que fui tendo maior contato com os equipamentos, programas e a complexidade na elaboração, fiz um novo orçamento que passou a $R \$ 40.000,00$, e que hoje já considero defasado. Para considerarmos qualidade de imagens, som, “designer" gráfico e de interatividade no multimídia é necessário investimento. Considerando a experiência adquirida ao desenvolver o presente trabalho e o contato com outros grupos de desenvolvimento de material em multimídia, se hoje fosse começar da estaca zero o orçamento mínimo seria de $\mathrm{R} \$ 200.000,00$.

Com o passar do tempo fui tomando consciência da complexidade na elaboração de um CD-ROM que iria além de equipamentos e recursos financeiros, e passei um longo período desacreditando da possibilidade da elaboração de um CDROM sem uma equipe de trabalho. Foi quando comecei a buscar parcerias, primeiro numa empresa em São Paulo com experiência na área, depois com a equipe de um professor da UNICAMP que já desenvolvia alguns trabalhos, e em seguida com dois rapazes que haviam acabado de fazer um CD-ROM sobre plantas ornamentais. Todos se interessaram pelo projeto, mas a falta de recurso inicial e outros 
compromissos inviabilizaram a efetivação de parceiros para o desenvolvimento do projeto.

Por último fui à Escola do Futuro na USP (Núcleo de Pesquisa de Novas Tecnologias de Comunicação Aplicadas à Educação), e esse contato se revelou bastante efetivo. A equipe de trabalho não podia ser melhor: estavam envolvidos na elaboração de três CD-ROM's e tinham acabado de ganhar um prêmio Nacional de Software com um dos CD. Fizemos algumas reuniões, nas quais interessaram-se pelo projeto. $\mathrm{Na}$ época havia a possibilidade de um novo financiamento por uma grande empresa para novos projetos, onde o CD-ROM da Mata Atlântica se encaixaria, mas a história se repetiu e a parceria para o desenvolvimento do projeto não deu certo.

Bem, mas nem tudo foi em vão. Acabei fazendo um curso que eles ofereciam sobre Tool Book básico de Multimídia. Foi quando clareou o caminho, aprendi a utilizar as ferramentas necessárias. Tinha um equipamento simples, mas suficiente. Arrumei o programa de autoria multimídia e comecei a trabalhar em casa. Consegui montar algo básico, nas dúvidas pedia socorro para a equipe da Escola do Futuro, e assim saiu o primeiro protótipo do CD-ROM da Mata Atlântica.

Além das dificuldades encontradas para aquisição de recursos, e estabelecimento de parcerias houve também a construção de conhecimento sobre geração e manipulação de arquivos de textos, detalhes das imagens e som, bem como a familiarização com os programas a serem utilizados na edição dos referidos arquivos e a programação do sistema de autoria multimídia. Um outro item de tirar o sono é a seleção do conteúdo CD-ROM, (que dá corpo a cada item tratado). Por se abordar diferentes temas sobre a Mata Atlântica o trabalho se tornou bastante árduo, pois a complexidade de cada tema possibilita a montagem de um CD-ROM específico. Considerando essa diversidade de temas, no presente trabalho foi desenvolvido um protótipo do CD-ROM, com a colocação de informações que considero essenciais sem torná-las superficiais. A maior dificuldade tem sido na seleção e organização das informações a serem abordadas através de texto ou 
locução, sendo que estas devem ser bastante compactas e precisas, para não tornar cansativa a interação com o usuário.

Para o levantamento das informações sobre a Mata Atlântica recorri a diversos profíssionais da área, bibliotecas e instituições como: Instituto Florestal, Instituto Agronômico de Campinas (IAC), Fundação Sistema Estadual de Análise de Dados (SEADE), Universidade de São Paulo (USP), Universidade de Campinas (UNICAMP), entre outros.

Com base nas informações e materiais coletados foi possível elaborado um primeiro "design" do protótipo do CD-ROM, o qual foi melhorado com as informações coletadas sobre os interesses de professores e alunos de $7^{0}$ série ao $2^{0}$ colegial, sobre temas da Mata Atlântica do Estado de São Paulo. 


\section{1- INTRODUÇÃO}

A realidade das áreas naturais no Brasil e no mundo torna-se cada dia mais alarmante. É corrente, nos meios de comunicação, a divulgação do avanço caótico e progressivo da degradação de nossos ambientes, em nome do desenvolvimento das populações humanas.

O estado de São Paulo é um exemplo desta realidade, onde grande parte da vegetação natural foi substituída pela agricultura, pastagem, e pelo avanço da urbanização. De acordo com o relatório sobre Mata Atlântica no período de 19851990 , dos $81,80 \%$ de cobertura florestal restam apenas $7,16 \%$ (SOS Mata Atlântica \& INPE, 1992/93). Assim, grandes áreas de vegetação natural transformaram-se em pequenos fragmentos. Entretanto a Mata Atlântica que apresenta uma alta diversidade biológica continua mantendo uma área significativa, sem contudo deixar de sofrer grandes pressões, onde se pode destacar o avanço da urbanização sobre as áreas naturais.

Além de seu importante papel ambiental, esta região possui características peculiares, agrupando grande diversidade populacional, desde grupos indígenas, caiçaras até grandes centros urbanos industrializados. É uma região de grande beleza natural, cheia de lendas, conflitos sociais, problemas ambientais e esperança de uma melhor qualidade de vida.

Considerando essas características, o desafio é conciliar realidades tão diversas buscando a sustentabilidade do ecossistema. A regra não é "só" criar ilhas de preservação ambiental rodeada, por conflitos como vemos hoje. Há 
necessidade também de se criarem alternativas e orientar o manejo das áreas naturais e urbanas, de forma sustentável, que promovam não só a conservação ambiental, mas também a melhoria da qualidade de vida e a viabilidade econômica.

Os esforços de entidades governamentais e não governamentais em preservar a Mata Atlântica são intensos. São inúmeros os estudos nesta área e movimentos da comunidade para maior compreensão e conservação destes ambientes.

Apesar desses esforços, o conhecimento (e interesse) por estas áreas se restringe a uma pequena parcela da população, enquanto a grande maioria permanece sem interesse e pouco participativa. Isso diminui as possibilidades de conservação da Mata Atlântica, sendo que o êxito desta conservação, envolve o conhecimento e a organização da população (Alves et al 1990).

Com isso, torna-se necessário reunir um grande volume de conhecimento teórico e prático de maneira a despertar o interesse e motivar as organizações da comunidade em geral a valorizarem ações concretas visando à conservação destas áreas.

Tendo em vista as necessidades acima, este trabalho se propõe a contribuir ao acesso as informações, através da elaboração de um protótipo de CD-ROM (Multimídia) sobre a Mata Atlântica do estado de São Paulo.

A Mata Atlântica do estado de São Paulo estende-se da região litorânea ao interior do Estado, apresentando-se como um dos ecossistemas mais complexos do Brasil e do mundo. A região litorânea se destaca com seus diversos ecossistemas, com isso este trabalho concentrou-se num primeiro momento nesta região, pois, o número de informações a serem trabalhadas é muito grande.

Torna-se importante que a comunidade tenha acesso as estas informações de maneira dinâmica e interativa, possibilitando uma maior diversidade de leituras da realidade. Neste sentido os novos recursos tecnológicos são de grande valia, 
tendo a multimídia como destaque.

O uso do computador passa, cada dia mais, a fazer parte de nosso cotidiano: presente nos supermercados, nos bancos, nas lojas, e nas escolas. Nas escolas, o computador pode desempenhar importante papel através de seu uso em propostas educacionais que valorizem a formação do aluno enquanto sujeito e objeto de sua própria educação, capaz de desenvolver a observação, análise crítica, conceitos, criatividade e participação.

$\mathrm{Na}$ perspectiva de elaborar um protótipo do CD-ROM sobre a Mata Atlântica como uma possível ferramenta para aplicação educacional, este trabalho foi desenvolvido em algumas etapas.

Inicialmente criou-se um roteiro básico como tópicos sobre a Mata Atlântica o qual foi enriquecido e melhorado com a realização de uma pesquisa através de um questionário, aplicado a 133 alunos (de primeiro e segundo graus de escolas particulares) e 5 professores, sobre o conhecimento e interesse dos mesmos a respeito da Mata Atlântica.

Essa dinâmica de trabalho possibilitou enriquecer e ampliar os tópicos iniciais e dar início a montagem do protótipo do CD-ROM.

$\mathrm{Na}$ etapa posterior, foi disponibilizado uma primeira versão do protótipo do CD-ROM para uma classe com 21 alunos do $2^{0}$ colegial, os quais após o uso do protótipo, fizeram valiosas críticas e sugestões para sua melhoria. Nesta primeira versão, alguns tópicos foram parcialmente desenvolvidos e outros apenas listados para serem desenvolvidos futuramente.

Também foi desenvolvido um jogo de desafio e aplicado junto a três alunos $2^{0}$ colegial, visando propiciar um contexto no qual eles pudessem utilizar alguns conteúdos disponíveis no protótipo do CD-ROM para a solução de um problema. A partir desse experimento procurou-se colher parâmetros para possível implementação de desafios dentro do protótipo do CD-ROM.

Os tópicos do presente trabalho, a serem apresentados a seguir, abordarão: 
os objetivos; uma revisão sobre os tópicos que compõem o protótipo; a metodologia de elaboração da pesquisa e do protótipo; os resultados e discussões das atividades; as considerações finais; as perspectivas futuras e a bibliografia citada. Em anexo estão disponíveis uma cópia dos elementos utilizados no desafio, assim como as telas do protótipo do CD-ROM da Mata Atlântica. 


\section{2- OBJETIVOS}

Geral:

- Contribuir para a conservação dos ambientes naturais, através de programas educativos que utilizem a informática como apoio para a informação e instrumento de comunicação.

Específicos:

- A partir de subsídios colhidos junto a professores e alunos da $7^{0}$ série do $1^{0}$ grau ao $2^{0}$ colegial do $2^{0}$ grau, desenvolver um programa de Multimídia reunindo informações sobre a Mata Atlântica do estado de São Paulo relativos a: tipos de vegetação, localização e mapas, ocupação, conservação e recuperação e um banco de informações. 


\section{3- REVISÃO BIBLIOGRÁFICA}

"O único homem construido é aquele que aprendeu como aprender, o que aprendeu a adaptar-se e a mudar, o que se deu conta de que nenhum conhecimento é garantido, mas que apenas o processo de procurar o conhecimento fornece base para a segurança. A qualidade de ser mutável, um suporte no processo, mais do que o conhecimento estático, constitui a única coisa que faz qualquer sentido objetivo para a educação no mundo moderno"

Carl Rogers (1985, p.126)

Com o olhar na direção deste desafio, de eterno aprendiz, aborda-se nesta revisão, a base de um conhecimento que inicia.

Em se tratando da produção de um protótipo de CD-ROM sobre a Mata Atlântica do Estado de São Paulo, foi necessário realizar inicialmente a delimitação da área de estudo, que se concentrou no litoral, devido ao grande número e a diversidade de informações a serem abordadas.

Para fundamentar o trabalho, realizou-se uma revisão bibliográfica sobre Informática e Educação Ambiental. Além disso buscou-se o aprofundamento de aluguns tópicos sobre a região litorânea, a serem abordados no protótipo:

Tipos de Vegetação (Mata de Encosta, Mata de Restinga, Mangue e Duna) Ocupação da Mata Atlântica (Urbanização, Agricultura, Populações Tradicionais e Turismo) 
Conservação e Recuperação da Mata Atlântica (Unidades de Conservação, Pesquisa na Mata Atlântica e Legislação Ambiental).

\section{1- A Informática}

\subsection{1- A Informática na Educação}

Segundo Fagundes apud Nogueira (1995)p.348 o uso do computador nas escolas vem da década de 70 , onde começam a surgir cursos técnicos de computação no Brasil. Havia uma "crença em que o software educacional pudesse suprir a falta de escolas e de professores. E que nada do que foi feito deu resultado. Nem poderia, complementa, porque não se buscava mudar a educação".

O computador por si só nada muda ou transforma na escola, mas a forma como é usado pode levar a resultados bastante positivos. É o que indica as pesquisas desenvolvidas pelo "Núcleo de Informática Aplicada à Educação"NIED da UNICAMP, que há 13 anos vem desenvolvendo trabalhos em escolas públicas no Brasil, com o uso de computador na escola.

$\mathrm{Na}$ década de 80 surgem os microcomputadores no Brasil e com eles as escolas particulares começam aos poucos a usar informática no ensino, com software importados. No início da década o governo promove encontros nacionais para discussão do problema e surge o EDUCON, formado pelas universidades (UNICAMP, UFRJ, UFRGS, UFMG, UFPe) com o objetivo de criar centros pilotos de pesquisa.

Em 1990 o Brasil participa de um intercâmbio, patrocinado pela OEA, com países latino-americanos, para promover a troca de experiências e o estímulo ao desenvolvimento da informática no ensino. A partir de então são criados Centros de Informática Educativas (CIEDS) sob a responsabilidade dos governos 
estaduais, com objetivo de atender a população e formar professores. Todavia, com o passar dos anos, ocorre um afastamento da proposta inicial de formar e atender a comunidade, devido a questões políticas divergentes.

Atualmente o uso de computador no ensino tem sido crescente, e as escolas particulares em massa, estão introduzindo em seus currículos o ensino da informática, gerando uma pressão para que também se use nas escolas públicas, o que segundo Ladim et al (1995) se dá principalmente com a finalidade de equalizar socialmente as oportunidades. Mas em geral esse avanço não é acompanhado de uma proposta pedagógica, subestimando a capacidade de ensinoaprendizagem da informática educativa, e passa a ser mais um instrumento de marketing das escolas frente à concorrência do mercado.

Barros (1988), destaca a importância do computador não como um fim em si mesmo, mas um recurso onde sua eficiência dependerá da forma como é utilizado e da capacidade de quem o utiliza. Já segundo Machado (1993), a presença do computador na escola possibilita uma dinâmica entre o tradicional e o novo, gerando um desafio para o docente, num exercício contínuo de aprender.

De acordo com Valente(1993), o computador está proporcionando uma verdadeira revolução no processo de ensino-aprendizagem, pois enriquece o ambiente de aprendizagem onde o aluno, interagindo com os objetos desse ambiente, tem a chance de construir seu próprio conhecimento. Transforma-se assim o aluno num observador ativo, construtor de seu conhecimento. Mas até o momento, no Brasil, a entrada do computador nas escolas tem criado mais controvérsias e confusão do que auxiliado a resolução de problemas na educação. Alguns exemplos disso são os questionamentos dos métodos e da prática educacional. Também há insegurança de alguns professores menos informados que receiam e refutam o uso de computador em sala de aula, com medo de serem substituídos pela máquina. 
De acordo com Chaves et al (1988), o computador pode induzir uma mentalidade mecanicista e cientificista, criando-se uma relação materialista com o mundo. Com isso o referido autor destaca que o computador deveria entrar nas escolas quando já houvesse maturidade por parte dos alunos para discutir sua aplicação e efeitos, apontando o $3^{0}$ colegial como o ideal.

A forma de abordar e pensar o computador nas escolas, também se difere dentro dos principais grupos de pesquisadores da informática educativa no Brasil, de acordo com a concepção de ensino-aprendizagem e o papel da escola no processo de formação do aluno. Segundo Nogueira (1995), podemos diferenciá-la em dois grupos: para autores como Fagundes (1992) e Valente (1993), a escola tem um papel transformador, e a aplicação da informática pode auxiliar neste processo. Já para outros autores como Litto (1993) e Carvalho (1992), o principal papel da informática na escola é o preparo dos alunos para o mercado de trabalho através da nova tecnologia.

Em outros países, como os Estados Unidos, a informática na educação está num estágio bastante avançado. De acordo com Dimenstein (1996), 500 mil a 1,5 milhão de crianças norte-americanas estão dispensando a escola e fazendo a sua formação por meios virtuais, como a Internet ou CD-ROMs educativos, (relato de Gilberto). Mas, apesar da Internet possuir as mais recentes publicações científicas em vários temas e de haver ótimos CD-ROMs educacionais, há também uma enorme quantidade de material de baixíssima qualidade educacional. Ainda, segundo a Folha de São Paulo, 17 de novembro de 1995, existe uma idéia mais ampla de educação que jamais poderá ser substituída pelo computador: a sociabilidade.

Segundo o filósofo britânico Gilbert Ryle apud Folha de São Paulo 17 de novembro de 1995, existe distinção entre dois tipos de saber: o "saber que" e o "saber como". No primeiro, a informação pode ser facilmente transmitida . Já o "saber como" necessita mais do que a informação apenas, é outra forma de 
transmissão de conhecimento, um exemplo é uma aula de natação. O risco da escola computadorizada é que se aprenda muito o "saber que" em detrimento do socialmente mais importante "saber como".

Segundo Valente(1993) no Brasil, há dois tipos de visões, as céticas e as otimistas sobre o uso da informática na educação. $O$ argumento da visão cética mais comum é a pobreza do nosso sistema educacional, que de acordo com o autor, a melhoria do ensino das escolas deve passar pelo aspecto físico da escola, salário de professores e uma mudança pedagógica onde se incluem os computadores.

Outros argumentos são a desumanização do ensino e das crianças, trocando professores pelas máquinas e deixando as crianças desumanas e robóticas. Segundo o autor, dificilmente isso ocorreria, sendo que na melhor das hipóteses ela usaria uma hora por dia o computador, muito menos do que a televisão no seu cotidiano, por exemplo. E por último, e talvez o maior desafio, é a dificuldade de adaptação da administração escolar, dos professores e dos pais a uma abordagem educacional que eles não vivenciaram. Esse, de acordo com Valente (1995), certamente é o maior desafio, que implica na mudança de postura dos membros do sistema educacional e na formação dos administradores e professores.

Já na argumentação da visão otimista, o uso do computador na escola tornou-se, uma tecnologia do futuro, um meio didático que motiva e desperta a curiosidade do aluno e, o mais importante, desenvolve o raciocínio e possibilita situações de resolução de problemas.

Segundo Chaves (1988), existe diferentes tipos de software educacionais que podem ser aplicados nas escola como:

- Tutoriais: são programas que ensinam conteúdos, dirigindo passo a passo o usuário na navegação.

- Exercício e prática: programas para exercitar e memorizar conteúdos, podendo ser utilizados para avaliação do aluno sobre o assunto. Possui uma abordagem 
restrita de estímulo e resposta.

- Simulação: o programa imita um modelo real ou imaginário, possibilitando ao usuário levantar e testar hipóteses, avaliando os resultados como se fossem na vida real. Numa simulação, experimentam-se conceitos e princípios, aumentando a compreensão teórico-prática.

- Enciclopédias em CD-ROM: programas para pesquisa de assuntos variados com recursos de animação, sons, vídeo, hipertextos (é um sistema de rede de associação de textos ligados entre si através de palavras chaves), etc. Também existem CD-ROM's com temas específicos, possibilitando grande interação com o usuário.

Além desses itens, os jogos e aplicativos (processador de textos, banco de dados e planilhas), podem desempenhar um importante papel educacional, desde que abordem conteúdos adequados e que possibilitem uma interação com o usuário.

Segundo Hernandes (1996), a produção de softwares nacionais e estrangeiros trazem, em seu formato e conteúdo, equívocos pedagógicos. Sendo que a maior parte deles se concentram na elaboração visual e estética do programa em detrimento a abordagem educacional que ele permite.

Vários programas foram elaborados com esses objetivos, sendo que no Brasil tem- se utilizado bastante o software LOGO, por possuir uma abordagem construtivista, oferecendo a criança o controle da máquina, sendo ela quem programa e determina as regras a serem utilizadas.

Por outro lado, o LOGO é bastante pobre em recursos audiovisuais onde o multimídia o supera, quando há ocorrência desse recurso. Já os softwares disponiveis no mercado para o trabalho em multimídia, são em sua maioria voltados para profissionais da área, e não para o uso no ensino, dificultando sua aplicação. Além da complexidade dos softwares profissionais, a elaboração de um multimídia requer conhecimento de diferentes softwares para processar as mídias 
(imagem, som, texto, vídeo, etc.) além de programas específicos que possibilitam a junção das mesmas.

$\mathrm{O}$ que se tem visto é que cada vez mais, empresas e profissionais desenvolvem Multimídias em CD-ROMs destinado ao ensino, mas muitas vezes preocupados apenas com o retorno econômico, sem valorizar as questões educacionais.

Segundo Senna (1995), embora sejam enormes as possibilidades da informática na escola, sua utilização, restringe-se a tímidas e monótonas instruções programadas e "mesmo com o surgimento do multimídia, o computador ainda não dispõe de rotinas que viabilizem a autonomia do usuário na definição do modo e das finalidades de sua utilização, associadas a mecanismos confiáveis de auto-avaliação"

De qualquer forma, os programas de multimídia tendem a avançar e suprir as falhas atuais, e o mercado está aberto a todo tipo de produto. Cabe aos educadores selecionar e indicar a seus educandos os que se adaptam as novas tendências impostas ao sistema de ensino.

\subsection{2- A Multimídia}

Esta é hoje a ferramenta mais completa criada para o uso em computação na atualidade, de acordo Vaughan (1994), o termo multimídia pode ser definido como as diversas combinações entre texto, som, arte gráfica, animação de imagens e vídeo transmitida pelo computador, sendo que, quando o controle de movimentação do conteúdo e das informações são fornecidos ao usuário, a multimídia torna-se interativa.

O uso da multimídia possibilita o estímulo de mais de um sentido humano no processo, através de :

-Som ( voz humana, música, efeitos especiais )

-Fotografia ( imagem estática ) 
-Vídeo ( imagem em pleno movimento )

-Animação ( desenho animado )

-Gráficos

-Textos (incluindo números, tabelas, etc.)

A utilização mais importante da multimídia segundo Chaves (1991) e Martin (1992), é que além de sua capacidade de guardar um grande número de informações, ela proporciona ao usuário sua transformação, em participante ativo na sua busca e recuperação, ou seja, um manipulador e processador de informações. Neste contexto o usuário:

- decide a sequência em que a informação vai ser apresentada ou recuperada e o seu próprio esquema de navegação pela informação;

- determina o ritmo e a velocidade da apresentação ou recuperação da informação;

- controla repetições, avanços, interrupções, sempre podendo retornar onde parou da vez anterior;

- estabelece associações e interligações entre informações diversas, mesmo que de natureza diferente ( textos, imagens, sons, por exemplo ), progredindo de um assunto ao outro, ou saltando de um meio ao outro;

- pode introduzir marcações e anotações nos textos e imagem, bem como comentário ao material lido, visto e ouvido, podendo também realizar cálculos com informações numéricas, eventualmente, inseridos nos textos;

- define os momentos em que, se desejar, pode-se avaliar seu conhecimento, se já possui as informações de interesse.

As possibilidades de utilização são as mais diversas possíveis, cabendo ao elaborador da multimídia, torná-las acessíveis ao usuário.

Segundo Vaughan (1994), a multimídia pode ser classificada de acordo com sua estrutura de movimentação (fluxograma), o que está diretamente relacionada com a possibilidade e a qualidade de interação do usuário com o programa. Estas estruturas podem ser diferenciadas em quatro diferentes tipos: 
- Lineares: o assunto tratado após iniciado vai até o final, sem possibilitar uma interação com o usuário, como a apresentação de um vídeo, como mostra a figura abaixo:

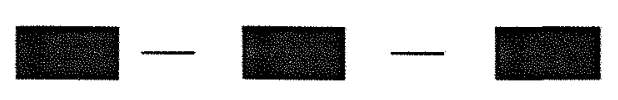

- Hierárquica: a divisão do assunto se dá através de módulos independentes, possibilitando uma interação parcial com o usuário pois os módulos não possuem ligações entre si, como mostra a figura:

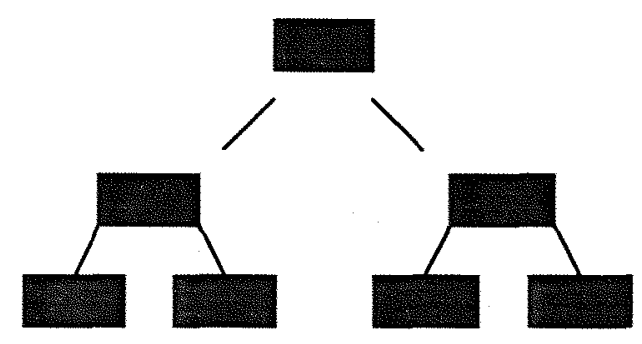

- Não Linear: os assuntos correlacionados são interligados através de nós ou links (ligações), possibilitando ao usuário uma interatividade total. Estas estruturas caracterizam o sistema de hipertexto:

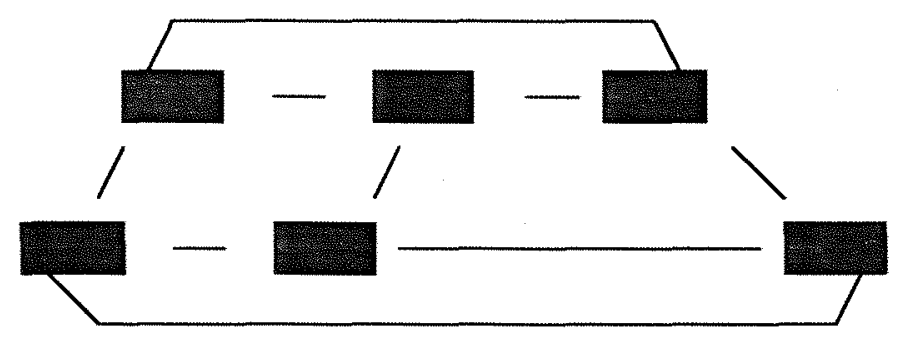

- Composta: é uma estrutura híbrida, onde pode combinar as várias estruturas anteriores, sendo bastante utilizada em softwares para ensino e treinamento.

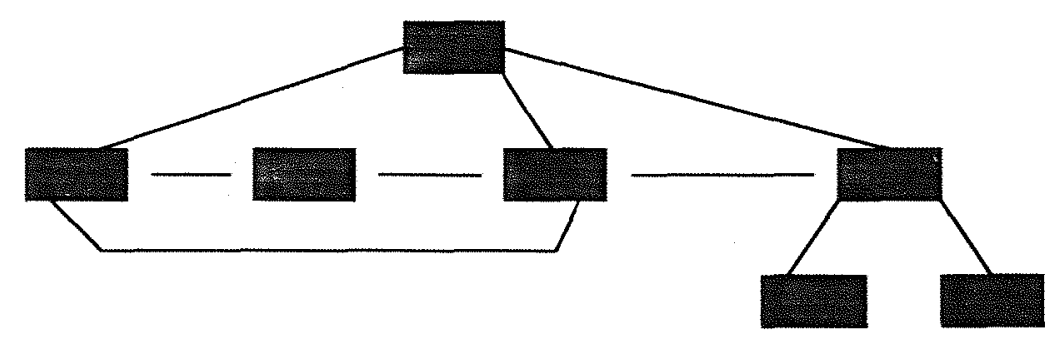


A multimídia, apesar de todas as suas possibilidades, requer um fator básico e fundamental: o domínio da ferramenta e de vários outros softwares para o tratamento das diferentes mídias, tornando-se assim uma ferramenta bastante complexa quando se pretende elaborar um programa de boa qualidade.

Vários autores afirmam sobre as grandes possibilidades da multimídia, mas pouco ou nada se diz sobre as etapas de trabalho e a complexidade da ferramenta. Já existem no mercado alguns softwares para a criação de multimídia, bastante simples, comparado aos profissionais, pois possuem uma programação préestabelecida, de telas e navegação, o que facilita a montagem do programa em multimídia. Mas estes softwares têm restrições em sua capacidade de trabalho e requerem, assim como os profissionais, o domínio de outros softwares para digitalização e tratamento das diferentes mídias a serem utilizadas no programa.

De acordo com Chaves (1991), uma das aplicações mais nobres e importantes da multimídia está na área de educação e treinamento.

No III Educar 96 - Feira e Congresso Internacional de Educação, realizada de 14 a 17 maio no Anhembi, São Paulo, com 150 expositores, foi dada grande ênfase na área de informática aplicada, onde a maioria dos expositores apresentou produtos como: equipamentos, projetos de informatização das escolas, treinamento de professores e alunos, consultoria, e programas.

Os programas, em sua maioria softwares educativos, tratavam dos temas através da multimídia, para alunos de primeiro grau, de primeira a quarta série com ênfase na alfabetização e matemática, sendo que seu uso tornou-se uma alternativa na abordagem de temas de difícil compreensão pelos alunos. Isso foi possível devido a sua grande capacidade de interatividade com o usuário e o uso de diferentes mídias.

A multimídia, apesar de estar presente na mais importante feira de educação do Brasil, tem sua oferta e qualidade ainda bastante limitadas, concentrando-se em alunos de primeiro grau. 
Quando se pensa em multimídia na área ambiental são raros os trabalhos encontrados. Apenas dois expositores em toda a feira possuíam produtos em multimídia diretamente relacionados a questões ambientais para alunos de primeiro e segundo grau. Um através do acesso via Internet a dois projetos, o Projeto Amazônia, onde alunos e professores têm a oportunidade de intercâmbio com a equipe de campo e demais escolas, sobre a flora, fauna, e as riquezas da Floresta Amazônica. O outro era o Projeto Educar: Uma Aventura Interativa, acompanhando a família Schürmann via Internet que está refazendo o percurso do navegador português Fernão de Magalhães, a circunavegação do globo. As escolas têm oportunidade de conhecer diferentes culturas e religiões, relembrar fatos históricos e estudar flora e fauna de cada região.

Outro expositor possuía um CD-ROM sobre a Origem dos Homens, uma produção francesa traduzida para a língua portuguesa.

O que se observa é que apesar do avanço da informática, da valorização da multimídia e da redução de seus custos, ainda se está distante de atender as necessidades e a realidade do ensino brasileiro, com equipamentos e softwares e CD-ROMs não apenas para o primeiro grau, mas para todos os níveis de ensino, com uma abordagem mais ampla, onde as questões ambientais sejam valorizadas.

\section{2- A Educação Ambiental e Materiais Didáticos}

A produção de um protótipo de CD-ROM sobre a Mata Atlântica, com uma perspectiva educacional, leva-nos a buscar fundamentos teóricos e práticos na educação ambiental, a qual se desenvolveu a partir da necessidade em conter a degradação ambiental.

Nossos antepassados, já alertavam para a importância em se proteger a natureza, os pensadores, filósofos, cientistas, artistas, religiosos, deixaram vários escritos e manifestos, sobre a conservação da natureza. 
Em 1962 o livro "Primavera Silenciosa" de Rachel Carson, foi um marco histórico com grande repercussão, causando discussões e inquietações mundiais a respeito da degradação dos ecossistemas e a necessidade em conservá-los.

Durante este período há um crescimento do movimento ambientalista mundial, encontros e conferências internacionais como o Clube de Roma em 1968 e a Conferência de Estocolmo em 1972. Nestas conferências foi gerada a importante Declaração sobre o Ambiente Humano e se estabeleceu o Plano de Ação Mundial. Este plano teve como objetivo, inspirar e orientar a humanidade para a preservação e melhoria do ambiente. Também reconheceu o desenvolvimento da educação ambiental como o elemento crítico para o combate à crise ambiental no mundo, e enfatizou a urgência da necessidade do homem reordenar suas prioridades (Dias, 1992).

Em 1977 realizou-se a Conferência Intergovernamental sobre Educação Ambiental em Tbilisi, Geórgia, CEI, ficando conhecida como a Conferência de Tbilisi, gerando um documento denominado: "As Declaração sobre a Educação Ambiental", destacando suas características, finalidades, objetivos e estratégias, determinando um marco na evolução da Educação Ambiental (UNESCO).

Uma importante estratégia de ação definida nesta Conferência, foi a criação de material pedagógico adequado para os diferentes públicos no auxílio do trabalho de Educação Ambiental, tendo em vista sua escassez e limitação quanto a seus conteúdos.

Já na Rio-92, o Fórum Global, que reuniu as Organizações NãoGovernamentais, elaborou-se o Tratado de Educação Ambiental para Sociedades Sustentáveis e Responsabilidade Global (Forum Internacional ONGs, 1992), definindo princípios, plano de ação, um sistema de coordenação, monitoramento e avaliação e grupos a serem envolvidos.

Deste Fórum pode-se destacar os princípios da educação para sociedades sustentáveis e responsabilidade global (Anexo A) 
Além destas grandes conferências, vários outros encontros ocorreram na América Latina. Segundo Dias, (1992), há uma forte referência dos participantes desses encontros para a necessidade, qualidade e conteúdo dos materiais didáticos, apontando para:

-abordagem ampla considerando aspectos, sociais, políticos, econômicos, culturais não apenas ambientais.

-incentivo à produção de materiais alternativos.

-produção de materiais tanto para escolas (educação formal) quanto para a comunidade (educação não formal), adequado à faixa etária, ao grau de escolaridade e ao conteúdo a ser abordado.

-incentivo à produção de caráter informativo e formativo.

Com base na necessidade de materiais em educação ambiental o Instituto Ecoar para Cidadania desenvolveu uma importante pesquisa, mapeando e avaliando os materiais impressos sobre educação ambiental disponíveis no Brasil Trajber et al (1996).

O levantamento desses materiais não se deu de forma exaustiva, mas possibilitou traçar um perfil quantitativo bastante representativo do banco de publicações em educação ambiental, nos diferentes estados, como podemos observar na Tabela 1. 
Tabela 1. Número de registro de material de educação ambiental por Estado.

\begin{tabular}{|c|c|c|}
\hline Estados & Monografias & Periódicos \\
\hline $\mathrm{AC}$ & 30 & 2 \\
\hline $\mathrm{AL}$ & 5 & \\
\hline$\overline{A M}$ & 9 & 1 \\
\hline $\mathrm{AP}$ & 24 & 1 \\
\hline $\mathrm{BA}$ & 48 & 3 \\
\hline $\mathrm{CE}$ & 2 & \\
\hline DF & 16 & 2 \\
\hline ES & 43 & 5 \\
\hline GO & 5 & 2 \\
\hline MA & 4 & \\
\hline MG & 27 & 1 \\
\hline $\mathrm{MS}$ & 11 & \\
\hline $\mathrm{MT}$ & 23 & 3 \\
\hline $\mathrm{PA}$ & 4 & \\
\hline PB & 5 & \\
\hline $\mathrm{PE}$ & 3 & 1 \\
\hline $\mathrm{PI}$ & 6 & 1 \\
\hline $\mathrm{PR}$ & 49 & 4 \\
\hline $\mathrm{RJ}$ & 67 & 11 \\
\hline \multicolumn{3}{|l|}{$\mathrm{RN}$} \\
\hline $\mathrm{RO}$ & 14 & \\
\hline RR & 1 & \\
\hline $\mathrm{RS}$ & 32 & 1 \\
\hline $\mathrm{SC}$ & 43 & 6 \\
\hline $\mathrm{SE}$ & & 1 \\
\hline SP & 324 & 21 \\
\hline TO & 5 & 1 \\
\hline sem Estados & 12 & 2 \\
\hline
\end{tabular}

Fonte: Trajber et al (1996)

De acordo com os dados do levantamento podemos observar a concentração de materiais em alguns estados, tendo como destaque o estado de São Paulo. O que pode estar associado a intensidade de problemas ambientais na área e o grau de preocupação e participação de diferentes grupos frente a esses problemas.

As publicações levantadas são compostas por diversos tipos de materiais e entidade que os produziram, como pode-se observar na Tabela 2 e Tabela 3. 
Tabela 2. Número de registro em educação ambiental por tipo de material

\begin{tabular}{|l|l|}
\hline Módulo Monografias & Módulo Periódicos \\
\hline livro didático: 20 & \multirow{2}{*}{ periódicos: 69} \\
\hline livro paradidáticos: 53 & \\
\hline literatura infanto-juvenil: 20 & \\
\cline { 1 - 1 } livro/folheto: 190 \\
\cline { 1 - 1 } catálogo/folder: 323 \\
\cline { 1 - 1 } cartilha: 62 \\
\hline brinquedo/jogo: 8 \\
\cline { 1 - 1 } evento: 15 \\
\hline outros: 120 \\
\hline
\end{tabular}

Fonte: Trajber et al (1996)

Tabela 3. Número de registro de material em educação ambiental por tipo de entidade que produziu:

\begin{tabular}{|c|}
\hline Módulo Monografias \\
\hline órgão federal: 36 \\
\hline $\begin{array}{l}\text { órgão estadual: } 178 \text { sendo: } \\
\text { - estadual de meio ambiente: } 155 \\
\text { - estadual de educação: } 8\end{array}$ \\
\hline $\begin{array}{l}\text { órgão municipal: } 184 \text {, sendo: } \\
\text {-municipal de meio ambiente: } 110 \\
\text { - municipal de educação: } 7\end{array}$ \\
\hline ONG: 164 \\
\hline editoras comerciais: 153 \\
\hline universidades/escola: 45 \\
\hline empresa:41 \\
\hline internacional/intergovernamental: 1 \\
\hline outros: 8 \\
\hline
\end{tabular}

Fonte: Trajber et al (1996) 
Os dados das tabelas anteriores apontam para a diversidade de materiais produzidos que podem ser encontrados no país, com enfoque para diferentes públicos. Também o envolvimento de diferentes organizações e entidades para a produção desses materiais, confirma a abrangência e a importância da educação ambiental nos dias atuais.

Mesmo com esse crescimento e avanço na produção de materiais impresso em educação ambiental, as carências são inúmeras, e devem ser minimizadas no futuro .

De acordo com Trajber et al (1996), em muitos materiais não ocorre coerência entre forma e conteúdo, discurso e prática. Sendo que estes também apresentam deficiência quanto ao tipo de linguagem que não condiz com a realidade do público a qual se destina, e muitas vezes apresentam baixa qualidade gráfica e conceitual.

O que deve ser destacado dentro da produção de materiais didáticos para educação ambiental é uma abordagem em que se valorize a experiência como forma de aprendizagem e construção do conhecimento. Essa abordagem deve ir além da informação apenas, estimulando aspectos morais e éticos do indivíduo. Também se aponta para as importantes características dos jogos e brincadeiras e da linguagem poética no estímulo, reflexão e argumentação, não se limitando num raciocínio lógico-formal (Trajber et al 1996).

"Apenas informar parece não ser suficiente para a formação de uma cidadania ambiental plena, que considere também a construção de novos valores, habilidades e atitudes. A educação ambiental precisa enfrentar uma situação de dupla natureza, cognitiva e ética, que se desdobra simultaneamente no conhecimento, na capacidades de julgamento ético e na ação moral" Trajber et al $(1996): 31$ 
A carência em materiais didáticos de boa qualidade, acontece não apenas no Brasil, mas em diversos países da América Latina, levando várias organizações e entidades a criarem estratégias para minimizar o problema, buscando referências e auxílio em instituições de outros países.

Devido a grande carência e solicitação, McCrea et al (1988) da State University of New York desenvolveu um trabalho, onde levantou 62 publicações de diferentes países, abordando diversos tópicos de interesse em educação ambiental, os quais eram de fácil aquisição pelos interessados. Isso ocorreu com o objetivo de indicar importantes publicações para consulta, que dessem apoio ao planejamento de programas de educação ambiental das instituições que os solicitavam.

Com isso se pode observar a necessidade de produção de materiais de boa qualidade, e que valorizem diferentes linguagens, como vídeo, computador, etc. $\mathrm{O}$ uso dessas linguagens tende a crescer nos próximos anos como já se pode observar nos endereços brasileiros na Internet, abordando temas sobre a educação ambiental.

O uso da Internet vem sendo adotado por órgãos governamentais e não governamentais, onde podemos destacar a Rede Brasileira de Educação Ambiental (http: // www.ciagri.usp.br/ rbea). Também uma nova linguagem que cresce a cada dia é o uso da multimídia, através de CD-ROM.

Desta forma, acredita-se que a abordagem e o conteúdo de temas ambientais, como o protótipo do CD-ROM da Mata Atlântica, vai ao encontro dos objetivos, finalidades, carências e necessidades no desenvolvimento da prática da Educação Ambiental, podendo, assim, tornar-se uma importante contribuição para o conhecimento desta região. 


\subsection{Vegetação da Mata Atlântica}

Vegetação, segundo Rizzini (1976), é o conjunto de vegetais ou cobertura vegetal encontrada em determinado local, que resulta das características de solo, clima e fauna, a qual é composta por sua flora, ou seja, as espécies taxonômicas que são determinadas por alterações climáticas, migrações, modificações pedológicas, mudanças faunísticas e acidentes geográficos .

A vegetação natural do Estado de São Paulo pode ser caracterizada em diferentes formações, tendo como uma das principais a Mata Atlântica.

Originalmente a Mata Atlântica abrangia, até o início deste século, 16 estados brasileiros, cobrindo cerca de $1.100 .000 \mathrm{Km}^{2}$, restando atualmente, apenas $5 \%$ da sua cobertura original de acordo com a Tabela 4 .

Tabela 4. Área dos remanescentes florestais do domínio da Mata Atlântica, desmatamento e incrementos entre 1985 e 1990.

\begin{tabular}{|l|l|l|l|l|l|l|l|l|}
\hline Estado & 1985 & \multicolumn{3}{l|l|}{} & 1990 & \multicolumn{2}{l|}{ Desmatamento } & \multicolumn{2}{l|}{ Incremento } \\
\hline & ha & $\%^{*}$ & ha & $\%^{*}$ & ha & $\%^{*}$ & ha & $\%^{* *}$ \\
\hline ES & 421.185 & 9.35 & 402.392 & 8.74 & 19.212 & 4.56 & 419 & 0.10 \\
\hline RJ & 937.129 & 21.50 & 896.234 & 20.97 & 30.579 & 3.26 & 2.729 & 0.29 \\
\hline SP & 1.792 .629 & 7.42 & 1.731 .472 & 7.16 & 61.720 & 3.44 & 563 & 0.03 \\
\hline PR & 1.646 .816 & 8.39 & 1.503 .098 & 7.73 & 144.240 & 8.76 & 522 & 0.03 \\
\hline SC & 1.627 .206 & 17.18 & 1.527 .794 & 16.25 & 99.412 & 6.11 & & \\
\hline
\end{tabular}

Fonte: Atlas da evolução dos remanescentes florestais e ecossistemas associados do domínio da Mata Atlântica no período de 1985-90. Fundação SOS Mata Atlântica e Instituto Nacional de Pesquisas Espaciais-INPE. (1992/93)

* em relação à área avaliada do estado

** em relação aos remanescentes de 1985

Remanescentes Florestais: Cobertura vegetal de formação florestal com mata densa, englobando vegetação primária e secundária. Não inclui vegetação de Restinga, Manguezais nem Dunas.

Incremento: Áreas em recuperação 
No estado de São Paulo a Mata Atlântica localiza-se na região litorânea, e tem como característica todo conjunto de vegetação da serra, a parte baixa próxima ao mar e alguns prolongamentos para o interior do estado, que podem ser subdivididos em formações distintas . A parte alta da serra denomina-se Mata de Encosta ou Floresta Pluvial Montana. Na parte baixa e próxima ao mar, com características bastante diferenciadas, estão a Mata de Restinga ou Floresta Pluvial Baixo Montana, Mangue e Dunas.

A Tabela 5, apresenta os tipos de vegetação e as respectivas áreas, obtidos pelo Inventário Florestal do Estado de São Paulo de 1990/92.

Tabela 5. Vegetação do litoral do Estado de São Paulo (1990/92)

\begin{tabular}{|l|l|l|l|l|l|l|l|l|l|}
\hline Região & \multicolumn{8}{|c|}{ Tipo de Vegetação (área-ha) } \\
\hline & Mata & Capoeira & Campo & Várzea & Restinga & Mangue & outros & Total & $\%$ \%* \\
\hline Litoral & 845.130 & 133.912 & 1.317 & 39.515 & 31.609 & $\mathbf{8 . 0 5 4}$ & 545 & 1.060 .082 & 31.83 \\
\hline
\end{tabular}

** \% em relação a área total da região

Fonte: São Paulo, 1993

A Mata de Encosta e a Restinga assim como a floresta tropical de outras regiões possuem uma dinâmica intensa de renovação onde as espécies vão se alternando ao longo do espaço e do tempo devido a perturbações naturais ou antrópicas (clareiras), ao contrário do que se pensava antigamente, como uma floresta estável e clímax.

O estudo da dinâmica florestal ainda é algo bastante recente no Brasil, em especial na Mata Atlântica. Este tipo de estudo é um elemento essencial para o gerenciamento e implantação de planos de manejo e de recuperação de áreas degradadas. Para isso é necessário a compreensão da dinâmica dos bancos de sementes e plântulas da floresta, pois esses definem padrões de populações e comunidades em relação ao estabelecimento, sucessão e regeneração natural.(Grime 1989 apud Baider, 1994). 
Na Mata Atlântica e Florestas tropicais maduras, os bancos de semente são em geral pobres e o banco de plântulas passa a ter principal papel na dinâmica de regeneração das florestas. As sementes provenientes das chuvas de sementes, germinam e se mantêm na forma de plântulas ou indivíduos jovens, por períodos variáveis, até que haja a possibilidade de crescimento por abertura do dossel (clareiras) (Baider, 1994).

Segundo Vásquez-Yanes \& Orozco-Segovia (1987), essa estratégia seria para minimizar a predação por herbívoros, pois os frutos e sementes da floresta tropical madura têm alto valor nutricional. Já as plântulas possuem menor recurso alimentar despertando pouco interesse, suportam melhor o ataque de fungos, têm maior capacidade de regeneração, toleram o crescimento à sombra, condição comum nas florestas e têm uma maior capacidade de sobrevivência sob condições desfavoráveis.

A sucessão em florestas tropicais pode ser separada de maneira didática em etapas, onde há predominância de um agrupamento de espécies com características ecológicas similares (guildas), na seguinte ordem (adaptado de Gómez-Pompa \& Vásquez-Yanes 1985 apud Baider, 1994 p8): “inicia-se com espécies herbáceas de ciclo de vida curto e dura semanas ou meses; seguem-se as espécies pioneiras arbustivas de ciclo de vida curto e tolerante à luz, que atingem entre 0,5 a 5,0 $\mathrm{m}$ de altura e promovem o inicio do sombreamento, permitindo a instalação das primeiras espécies umbrófilas, podendo durar de 6 a 18 meses; depois tornam-se dominantes as espécies pioneiras arbóreas de crescimento rápido (até $10 \mathrm{~m}$ ) e as primeiras secundárias iniciais de ciclo de vida mais longo que as anteriores, levando em torno de 3 a 10 anos. As espécies secundárias iniciais passam a ser as mais importantes, num ciclo que pode levar de 10 a 40 anos, iniciando a formação de um dossel, sob o qual as espécies intolerantes à luz - secundárias tardias e climácicas, de ciclo de vida longo, possam ser recrutadas e, posteriormente, as espécies secundárias tardias tornam- 
se as mais abundantes no dossel, observando-se climácicas no subosque e, algumas atingindo o dossel; culminando, a sucessão, com as espécies climáxicas tornando-se dominantes, com presença de secundárias tardias e muitas espécies no subosque, além de lianas e epifitas, com dossel fechado e contínuo, com a manutenção das espécies dos estágios anteriores dando-se por aberturas no dossel. Na verdade, este é um processo contínuo e pode ocorrer sobreposição, num mesmo local".

A estrutura típica de uma floresta tropical é aquela onde muitas espécies estão representadas por poucos indivíduos, sendo difícil estabelecer mudanças, pois os estudos têm um tempo menor que a geração de espécies florestais (Uhl et al. 1988). A taxa de mortalidade de adultos da comunidade é, via de regra, constante (em torno de 1 a $2 \%$ ao ano) e é similar a de recrutamento, mantendo a densidade do componente arbóreo (Phillisps \& Gentry, 1994).

A vegetação de mangue e duna também possui uma dinâmica própria na ocupação de áreas degradadas e na sua manutenção, mas totalmente diferente, das Matas de Encosta e Restinga, isso devido a própria estrutura simplificada dessas vegetações com poucas espécies e desenvolvendo a pleno sol.

Com base nesta descrição inicial passa-se a detalhar um pouco mais os diferentes tipos de vegetação presentes na Mata Atlântica.

\subsection{1- Mata de Encosta}

Floresta que recobre a serra do mar com uma formação de árvores de grande porte entre $20-30 \mathrm{~m}$, com algumas emergentes com $40 \mathrm{~m}$. Apresenta um subosque sombrio e úmido onde vegetam inúmeras ervas e epífitas (Giulietti, 1992 ).

Em estudo realizado por Silva \& Leitão Filho (1982), no município de Ubatuba (SP) referem-se à presença de 41 familias, 87 gêneros e 123 espécies, citam como as famílias mais importantes : Euphorbiaceae, Lauraceae, 
Leguminosae, Myrtaceae, Palmaceae e Rubiaceae. Esses autores consideram como as espécies de maior valor de importância para a região, as seguintes : Mabea brasiliensis, Hieronyma alchorneoides, Syagrus pseudococos, Eriolheca pentaphylla sp. wittrocriana, Sloanea guianensis, Bathysa gymnocarpa, Sclerolobium denudatum, Guapira calycantha, Malovetia arborea e Qualea gestasiana.

Rizzini (1988) destaca a importância das famílias Melastomataceae, Fabaceae, Orchidaceae que apresentam cerca de 1000 espécies. $O$ referido autor ressalta também as Palmaceae destacando os gêneros Euterpe e Genoma, e constata que $40 \%$ das espécies que ocorrem na Mata Atlântica são espécies endêmicas, apresentando uma biodiversidade superior à Floresta Amazônica.

Siqueira (1994), listou as principais espécies, gêneros e familias levantadas em 192 trabalhos de florística no domínio da Mata Atlântica do Brasil onde a região Sudeste concentra as maiores riquezas de espécies, gêneros e famílias, enquanto a Região Sul concentra as menores riquezas de acordo com a Tabela 6.

Tabela 6. Ocorrência das espécies, gêneros e famílias, por Região, nas 63 localidades amostradas de Mata Atlântica. Utilizado os taxons identificados até espécies.

\begin{tabular}{|l|r|r|r|r|r|r|r|}
\hline & \multicolumn{3}{|l|}{ NORDESTE } & \multicolumn{3}{l|}{ SUDESTE } & \multicolumn{2}{l|}{ SUL } & \multicolumn{1}{l|}{ TOTAL } \\
\hline & $\mathrm{N}^{0}$ & $\%$ & $\mathrm{~N}$ & $\%$ & $\mathrm{~N}$ & $\%$ & \\
\hline ESPECIES & 292 & 22 & 1134 & 85 & 244 & 18 & 1338 \\
\hline GÊNEROS & 272 & 59 & 390 & 85 & 151 & 33 & 460 \\
\hline FAMÍLIAS & 66 & 73 & 88 & 98 & 62 & 68 & 91 \\
\hline
\end{tabular}

Fonte: Siqueira (1994)

Várias espécies que ocorrem nesta área são de madeiras nobres com alto valor comercial. Há também espécies de interesse alimentar, como o palmito, e espécies de valor paisagístico como: bromélias, orquídeas e filodendros. Todas 
essas espécies despertaram e despertam grande interesse na sua utilização, estimulando a exploração clandestina em grandes áreas da Mata Atlântica.

Devido a ocorrência em áreas de difícil acesso na serra, a Mata de Encosta foi a vegetação que se manteve mais conservada ao longo de todos esses anos, frente à ocupação devastadora da Mata Atlântica.

\subsection{2- Mata de Restinga}

Restinga é o ecossistema adjacente ao oceano encontrado em planícies arenosas recobertas por uma vegetação arbórea e arbustiva, denominada Mata de Restinga (Araújo, 1987). Dados levantados em 1993, afirmam que existe hoje no Estado de São Paulo uma área remanescente de 31.609 ha (São Paulo, 1993).

Em estudos realizados na Ilha do Cardoso, Kirizawa et al (1992), concluem que a Mata de Restinga possui dois estratos ou mais. O número de estratos irá variar de acordo com a qualidade do solo, a qual depende do teor de matéria orgânica e húmus que se encontram em sua superfície dando-lhe uma coloração fortemente escura .

Nas áreas de solo com maior qualidade, a mata chega a atingir $20 \mathrm{~m}$ de altura, dividindo-se em 4 diferentes estratos com algumas espécies principais:

- estrato emergente: Calophyllum brasiliensis Camb, Matayba elaeagnoides Radlk, Didymopanax navoroi A. Sampaio

- estrato superior: Rapanea ferruginea (R. \& P.) Mez, Andira fraxinifolia Benth, Erythroxylum vacciniifolium Mart, Ocotea pulchella (Ness.) Mez.

- estrato médio: Gomidesia gaudichaudiana Berg, Andira anthelmia (Vell.) Macbr, Endlicheria panculata (Spreng.) Macbr, Nectandra grandiflora Ness \& Mart. ex Ness

- subosque: Xylopia langsdorffiana St. Hil. \& Tul, Marliera polygama Berg, Geonoma gamiova B. Rodr, Geonoma elegans Mart. 
Também é comum a presença de epífitas nesta vegetação como: Plylodendron bipinatifidum Schott, Tillandsia geminiflora Brongn, Cattleya forbsii Lindl.

\subsection{3- Mangue}

Grupo de plantas que se desenvolve na Zona Litorânea, em substrato plano, lodoso, bordejando estuários, enseadas, lagos, baías etc. Segundo Lambert (1969), o termo Mangue abrange a vegetação, o solo e tudo o mais que nele se encontre, como por exemplo, animais. No Estado de São Paulo a área com vegetação de Mangue remanescente é de 8.054 ha (São Paulo, 1993).

O Manguezal é composto por espécies lenhosas e perenifólias, um tipo singular de vegetação litorânea, extremamente especializada, capaz de desenvolver modificações morfológicas, anatômicas e fisiológicas que permitem colonizar terrenos alagados, periodicamente pela maré. Essa espécies não suportam temperaturas baixas onde a média favorável ao seu desenvolvimento é de $20^{\circ} \mathrm{C}$, com variações não excedendo os $5^{\circ} \mathrm{C}$ e limita-se a "habitats" salinos ou salobros marinhos (Herz, 1991).

Os manguezais normalmente estão associados a regiões estuarinaslagunares, desempenhando uma importante função na cadeia alimentar (berçário da vida marinha), enriquecendo suas águas com material particulado. Esses materiais são proveniente da decomposição orgânica, que por sua vez irá manter grande quantidade de microorganismos responsáveis na alimentação de peixes e crustáceos, e assim se inicia um dos mais importantes ciclos da vida no litoral. Também é conhecida sua capacidade de acumular partículas sedimentares provenientes de províncias continentais, evitando o assoreamento dos canais de navegação, reduzindo assim o custo de drenagem (Herz, 1991). 
O Manguezal desempenha importante papel na manutenção das espécies, e são essas que por sua vez garantem a sobrevivência de muitas famílias das regiões litorâneas.

"Demonstrar o potencial energético e alimentar dos ecossistemas de manguezais é relativamente fácil, quando verificamos seus antecedentes econômico-sociais nas comunidades litorâneas, desde sua existência que retrocede a pré-história, integrando a paisagem costeira com a construção dos sambaquis. É um sistema de suporte à vida, suprindo de alimentos os grupos primitivos, ainda representados por seus descendentes, desde o inicio da colonização portuguesa, mesclada com indigenas que guardam seus traços étnicos no atual caiçara" (Herz, 1991).

No Brasil é vasta a extensão ocupada pelo Manguezal, aparecendo em quase toda a orla marítima. Estende-se desde o extremo norte no Amapá, a $2^{\circ}$ de latitude Norte, até ao litoral sul de Santa Catarina, na foz do Rio Araranguá, a cerca de $29^{\circ}$ de latitude Sul.

Autores como Hamilton \& Snedaker (1984), apud Herz (1991), destacam a potencialidade do Manguezal, com o uso múltiplo da madeira em construção diversas e como combustível. Creio que os autores estão equivocados, pois pensar em corte de manguezais, é fechar os olhos para os benefícios que ele pode trazer ainda vivo. $\mathrm{O}$ corte dos manguezais desconsidera também toda a problemática ambiental que vivemos, sem considerar as dificuldades de corte e extração da madeira, assim como a falta de costume e tradição em sua utilização, mesmo pelas comunidades litorâneas tradicionais.

Os Manguezais apresentam uma baixa diversidade de espécies, e segundo Luederwaldt $(1919,1929)$, Lambert (1969), Herz (1991), são compostos por apenas três a quatro espécies principais: Rhizophora mangle Linn., Laguncularia racemosa Gaertn., Avicennia schaueriana Jacq., nas áreas mais secas de transição 
ocorre: Hibiscus tiliaceus Linn., Acrostichum aureum Linn. As epifitas, são raras, limitando-se geralmente a algumas bromeliáceas e líquens. Em estudos na Baixada Santista, Luederwaldt (1919) identificou algas epífitas como: Bostrychia brasiliana Moeb. e Catenella impudica Kütz.

O solo do Mangue segundo Lambert(1969), é do tipo areno barrento (AB), tendo como frações determinantes, $42 \%$ de areia fina e $35 \%$ de limo.

$\mathrm{O} \mathrm{pH}$ do solo está em torno de 5 , sendo que possui altas concentrações de íons $\mathrm{S}+, \mathrm{Ca}+, \mathrm{Mg}+, \mathrm{K}+\mathrm{e} \mathrm{Na}+$, cerca de 39 vezes maior que o solo de Dunas.

O IPT (Seção de Análises de Minérios e Água Industriais) procedeu a determinação de M.O.(matéria orgânica), M.I.(matéria inorgânica) de U (teor de umidade) no solo de Mangue e Duna, como mostra a Tabela 7.

Tabela 7. Teor de matéria orgânica (M.O.),umidade (U) e matéria inorgânica (M.I.) nos solos de Mangue e Dunas

\begin{tabular}{|c|c|c|c|}
\hline & M.O & $\mathrm{U}$ & M.I \\
\hline Mangue & $16,5 \%$ & $64,1 \%$ & $19,4 \%$ \\
\hline Dunas & $0,31 \%$ & $0,43 \%$ & $99,26 \%$ \\
\hline
\end{tabular}

Fonte: IPT (Instituto de Pesquisa Tecnológica)

Os mangues apesar de toda sua importância, ainda é visto como uma área suja de pouco valor, e têm sido, sistematicamente eliminado em grandes áreas do litoral paulista, principalmente pela especulação imobiliária. 


\subsection{4- Dunas}

Possui uma formação vegetal com predomínio de espécies halófilas herbáceas, que se estende pela orla marítima, ocupando as areias da parte superior da praia, adaptadas à alta luminosidade, à salinidade da água trazida pela maré e pelo vento, à seca na camada superficial da areia e pelas constantes movimentação do substrato (Kirizawa et al, 1992).

Segundo Andrade (1968), a vegetação dessa área apresenta adaptações morfofisiológicas que permitem desenvolver-se em condições adversas. Geralmente as espécies são rastejantes e acompanham a mobilidade do substrato evitando o soterramento e também contribuem para a fixação das Dunas.

No litoral paulista as espécies mais comum são: Blutaparon portulacoides (St.Hil) Mears., Hydrocotyle bonariensis Lam., Ipomoea pescaprae (L.)R.Br., Remira maritima Aubl. (Kirizawa, (1992); Hueck, (1955)) .

As Dunas no litoral paulista são pouco expressivas, quando comparadas à Região Nordeste, devido à própria formação geomorfológica, onde a serra mais se aproximou do mar, reduzindo os bancos de areia e favorecendo outros tipos de vegetação.

Podemos destacar o litoral sul de São Paulo, com a maior ocorrência de Dunas, onde a Ilha do Cardoso e Ilha Comprida possuem as áreas mais importantes.

\subsection{Ocupação da Mata Atlântica}

O litoral paulista sempre foi ocupado por populações humanas, o que mudou ao longo das décadas, foi o modelo e a intensidade de ocupação. No início, predominavam os índios da tribo Tupi-Guarani, ao longo de todo litoral, nas partes planas de restinga e próximo à serra. Com a chegada dos brancos grande parte da população indígena foi eliminada, pela violência ou por doenças 
desconhecidas por eles.

Os novos grupos vieram com interesses de extrair riqueza, como ouro e produtos agrícolas, e ampliar seus poderes. Com isso foram se criando centros urbanos, e com eles o aumento da população, a capacidade produtiva e mais tarde a industrialização. Todas estas fases, que tiveram seus altos e baixos, se por um lado trouxeram o avanço, por outro deixaram um rastro de degradação do ambiente, desestruturação das populações tradicionais e a baixa qualidade de vida de grande parte da população, principalmente nos centros industrializados.

Os séculos XVII ao XIX foram marcados pela intensa ocupação do Litoral Norte, com diversas atividades como: a cana de açúcar, o caminho do ouro para o exterior (século XVI e XVII) vindo de Minas Gerais, Goiás e Mato Grosso. No século XVIII houve um retorno da atividade agrícola, tendo seu auge no século XIX com o ciclo do café, sendo que neste período já se mostravam grandes áreas degradadas, e uma baixa produção agrícola, com seu solo pobre e erodido pelas práticas de cultivo inadequada. O litoral norte entrou no século $\mathrm{XX}$ marginalizado, concentraram-se as transformações sócio-econômica em Santos e no interior do estado, promovidas pelos fazendeiros de café destas regiões (Silva 1975).

Ao longo de décadas, o litoral paulista foi se transformando em grandes centros urbanos industrializados, na Baixada Santista, em extensas áreas agrícolas, prevalecendo a bananicultura, no vale do Ribeira e a crescente ocupação pelo turismo, no Litoral Norte de São Paulo, sendo que o grande facilitador para esse desenvolvimento, foram as construções das rodovias.

Em meados da decada de 70, foi inaugurado um trecho da rodovia BR-101 entre Santa Cruz, no Rio de Janeiro, e Ubatuba, no litoral paulista, dando início a uma grande transformação social e ambiental da região, devido a especulação imobiliária. 
"Com prestígio político na época o senhor Carlos Lacerda, teve prévio conhecimento do traçado da rodovia, onde juntamente com empresas estrangeiras, legalizou títulos de terra em grande parte do litoral, ocasinando a expulsão dos habitantes da região, os "caiçaras", e comunidades indígenas Guarani, de suas posses centenárias, obrigando-os a mudarem-se para a periferia das cidades da região" (Siqueira 1989).

A chegada das rodovias dos Tamoios (SP-99) em 1939, a SP-55 em 1955 interligando Ubatuba, Caraguatatuba e São Sebastião (hoje um trecho da RioSantos) e a SP-125 entre Ubatuba e Taubaté na década de sessenta, acentuaram definitivamente o processo de ocupação no litoral norte paulista. A partir de 1950, com o advento do turismo, grandes transformações sócio-econômicas ocorreram dando início ao processo de urbanização. Já o porto de São Sebastião, construído entre 1936-42, que somente se define com a instalação do terminal Marítimo da Petrobrás em 1969, ampliou o comércio com outras regiões do país e exterior (Silva, 1975).

Na década de 80, no governo de João Batista Figueiredo, foi retomada a construção de alguns trechos da estrada entre Bertioga e São Sebastião, e mesmo depois de finalizada a Rio/Santos, as agressões ambientais não cessaram, ao contrário, iniciou-se uma nova fase de devastação, onde o agente principal foi a especulação imobiliária.

\subsection{1- Urbanização}

A região do Litoral Norte e parte da Baixada Santista, representaram e representam ainda hoje uma importante área de lazer para as populações dos grandes centros urbanos como São Paulo, transformando o lazer em seu maior "produto". Já na Baixada Santista, principalmente Santos, Cubatão, o "produto" é diferenciado, onde predomina o setor secundário, com a industrialização, e no 
Litoral Sul há predominância do setor primário, tendo a agricultura como seu principal "produto" (FUNDAÇÃO SEADE, 1982).

Todas essas atividades, mesmo em setores e intensidades diferentes, levou a um crescimento considerável da população. Com base nos dados da Tabela 8, pode-se observar a população e sua distribuição no meio urbano e rural, residente nos municípios da região em 1980 e 1993, bem como as respectivas áreas territoriais e densidades demograficas. 
Tabela 8. Distribuição da população residente e rural em diferentes municípios da região do litoral do estado de São Paulo

\begin{tabular}{|c|c|c|c|c|c|}
\hline \multirow[t]{2}{*}{ Municípios } & \multicolumn{2}{|c|}{$\begin{array}{c}\text { População } \\
\text { Residente } \\
\left(\mathrm{n}^{\circ} \text { hab) }\right.\end{array}$} & \multirow{2}{*}{$\begin{array}{c}\text { População } \\
\begin{array}{c}\text { Rural } \\
\left(\mathrm{n}^{0} \text { hab }\right)\end{array}\end{array}$} & \multirow[t]{2}{*}{$\begin{array}{c}\text { Área } \\
\left(\mathrm{km}^{2}\right)\end{array}$} & \multirow[t]{2}{*}{$\begin{array}{c}\text { Densidade } \\
\text { Demográfica } \\
\left(\mathrm{n}^{\circ} \mathrm{hab} . / \mathrm{km}^{2}\right)\end{array}$} \\
\hline & ano 1980 & ano 1993 & & & \\
\hline Apiaí & 26.821 & 27.452 & 14.933 & 982 & 22,29 \\
\hline Barra do Turvo & 4.857 & 7.486 & 3.893 & 1.013 & 7 \\
\hline Bertioga & $-\cdots$ & 11.459 & $-\cdots$ & 482 & - \\
\hline Biritiba Mirim & 13.316 & 18.518 & 5.805 & 414 & 43,05 \\
\hline Cananéia & 7.692 & 10.076 & 1.973 & 1.272 & 7,58 \\
\hline Caraguatatuba & 33.563 & 56.548 & 577 & 480 & 110,34 \\
\hline Cubatão & 78.439 & 92.363 & 321 & 148 & 615,20 \\
\hline Eldorado & 11.272 & 13.384 & 7.694 & 1.712 & 7,68 \\
\hline Guarujá & 150.347 & 219.665 & $-\cdots$ & 137 & $1.531,49$ \\
\hline Ibiúna & 31.615 & 52.424 & 12.716 & 1.088 & 45,11 \\
\hline Iguape & 23.306 & 26.153 & 7.051 & 1.964 & 13,40 \\
\hline Ilha Comprida & $-\cdots$ & 2.823 & $\ldots$ & 182 & 15 \\
\hline Ilha Bela & 7.743 & 14.719 & 228 & 336 & 40,32 \\
\hline Iporanga & 4.719 & 4.568 & 3.523 & 1.277 & 3,62 \\
\hline Itanhaém & 27.245 & 49.540 & 1.289 & 581 & 79,12 \\
\hline Itapecerica da Serra & 60.072 & 91.300 & 3.189 & 136 & 283,09 \\
\hline Itariri & 9.419 & 11.839 & 4.602 & 295 & 39,23 \\
\hline Jacupiranga & 28.417 & 15.452 & 11.207 & 640 & 35,71 \\
\hline Juquiá & 15.132 & 17.182 & 7.281 & 865 & 19,62 \\
\hline Juquitiba & 12.402 & 21.364 & 3.850 & 550 & 36,12 \\
\hline Miracatu & 17.333 & 19.165 & 11.816 & 980 & 19,35 \\
\hline Mongaguá & 9.828 & 20.913 & 99 & 135 & 140,46 \\
\hline Pariquera-Açu & 11.281 & 13.391 & 5.065 & 370 & 35,59 \\
\hline Pedro de Toledo & 6.032 & 8.100 & 3.705 & 631 & 12,36 \\
\hline Peruibe & 18.241 & 36.024 & 1.346 & 328 & 100,48 \\
\hline Praia Grande & 65.374 & 136.219 & $-\cdots$ & 145 & 851,68 \\
\hline Registro & 38.965 & 50.247 & & 688 & 71,14 \\
\hline Ribeira & 7.455 & 4.017 & 5.746 & 356 & 8,97 \\
\hline Santos & 416.418 & 417.714 & 1.943 & 271 & 569,07 \\
\hline São Sebastião & 18.839 & 36.867 & 392 & 479 & 70,39 \\
\hline São Vicente & 191.997 & 281.504 & 131 & 146 & $1.840,63$ \\
\hline Sete Barra & 11.258 & 12.578 & 7.858 & 1.062 & 11,75 \\
\hline Tapiraí & 5.094 & 5.827 & 3.586 & 720 & 7,98 \\
\hline Ubatuba & 26.927 & 51.475 & 2.449 & 682 & 69,40 \\
\hline TOTAL & 1.391 .419 & 1.858 .356 & 134.268 & *21.547 & \\
\hline
\end{tabular}

Fonte: SEADE - Perfil Municipal do Estado de São Paulo (1995)

(*) A diferença em relação à área total das bacias hidrográficas que compõem a vertente marítima (21.564 $\mathrm{Km}^{2}$ ), deve-se aos municípios de Biritiba-Mirim, Ibiúna, Itapecerica da Serra, Juquitiba e Tapiraí, os quais possuem apenas parte de seus territórios na região do litoral paulista. 
Com base nos dados podemos destacar a Baixada Santista, onde Santos é a cidade de maior concentração populacional, já no Litoral Norte, Caraguatatuba lidera.

Nestas duas regiões, ocorre um crescimento temporário, principalmente no final do ano e carnaval, devido ao grande fluxo de turistas. chegando a elevar em média oito vezes a população normal nessas cidades, podendo atingir doze vezes mais, como é o caso de Mongaguá, no ano novo (Folha de São Paulo de 7 de Janeiro de 1997).

No Vale do Ribeira os municípios de Registro e Jacupiranga concentram quase $50 \%$ da população residente nessa área do litoral.

Apesar de cada região possuir características diferenciadas, o crescimento demográfico foi, e ainda é intenso, em algumas regiões.

Em 1960 a população da costa norte era predominantemente rural, com exceção do município de São Sebastião. Já em 1970 essa região apresentou uma taxa de urbanização de $81 \%$, semelhante a do estado no mesmo período $(80,3 \%)$. $\mathrm{O}$ crescimento no litoral Norte se acentuou nas últimas décadas. Enquanto a população do Estado apresentava índice de crescimento de 40,9\%, entre 1970 1980 , a costa norte apresentou um crescimento na ordem de $82,8 \%$ decorrente das imigrações.

Esta rápida urbanização, se por um lado trouxe o "desenvolvimento" sócioeconômico para a região, por outro, acentuou a desigualdade social, afastando os mais pobres das praias que passaram a ocupar terrenos próximos à serra, descaracterizando antigos bairros caiçaras e atraindo novos imigrantes de Minas Gerais e Nordeste. Essa situação se dá principalmente pelo emprego sazonal, tanto na construção civil como nas pousadas e no comércio, e a falta de repressão para invasões de terrenos públicos e privados (Agostinho, 1996).

Atualmente o litoral norte passa por um novo processo, o da "favelização", onde as praias (Juqueí, Maresias, Barra do Sahy, Toque-toque, Boiçucanga) no 
município de São Sebastião são os principais pontos. Enquanto a cidade apresenta um crescimento de $5,4 \%$ ao ano as favelas chegam a mais de $100 \%$, como é o caso de Maresia com 139\% ao ano (Folha de São Paulo, 20 outubro, 1996)

O trabalho desenvolvido por Luchiari (1992), na região de São Sebastião, aponta para o descaso dos orgãos públicos competentes, onde os grupos sociais (turistas, caiçaras e imigrantes), não são ouvidos no processo de tomada de decisão do planejamento regional.

"..com isso os problemas se avolumam e começam a se superpor. $O$ interesse público está dividido entre as elites, o público em geral e os habitantes da área, os quais são conflitantes, mas a população não é ouvida, respeitada, ela sequer compreende o processo de tomada de decisão. As dimensões simbólicas, estéticas, culturais não são levadas em consideração para o planejamento, quer seja planejamento sócio-econômico ou de preservação ambiental. É como se estas dimensões pudessem ser dissociadas das estratégias de sobrevivência". Luchiari (1992)

\subsection{2- Agricultura}

A agricultura, na Mata Atlântica, está concentrada na região sul, no Vale do Ribeira, tendo como sede a cidade de Registro. Esta região está situada numa área onde a serra se afasta da costa litorânea formando grandes planícies, que favoreceram a ocupação pela agricultura, tendo a banana como principal produto.

Devido ao alto custo de investimento necessário e a falta de incentivo para a ocupação das planícies, que sofrem inundações periódicas, a agricultura ocupa apenas $0,14 \%$ da área total, concentrando-se nas partes mais elevadas entre rios, menos sujeito a cheias. Em função desta situação os produtos limitam-se ao arroz, à banana, ao chá, e algumas hortaliças. Quanto à pecuária, não pode ser caracterizada como atividade econômica significativa, apresentando rebanhos de 
baixa produtividade (Vieira \& Mirabelli, 1989).

O Vale do Ribeira teve grande influência da colonização Japonesa, e sempre concentrou grande parte de sua população na zona rural. Em 1980 enquanto a região do litoral como um todo apresentava um grau de urbanização da ordem de $93,05 \%$, o Vale do Ribeira ainda possuía, nesta data, $42,71 \%$ de sua população no meio rural (FUNDAÇÃO SEADE, 1982).

\subsection{3- Populações Tradicionais}

As populações tradicionais são representadas pelos índios Guarani e os "caiçaras" descendentes de índios, negros, portugueses e também, de numerosos piratas que visitavam este litoral.

Os índios Guarani são representados atualmente por 7 grupos ao longo do litoral paulista com uma população de 1600 índios aproximadamente, sendo que ainda há várias aldeias sem o reconhecimento governamental (Instituto Socioambiental, 1995).

As tribos Guarani do litoral paulista são compostas pelos grupos Mbyá, e Nandeva, os quais possuem características migratórias, onde ocupavam vastas áreas na Argentina, Paraguai, Uruguai e o litoral brasileiro. Hoje restam pequenos grupos, mas que ainda mantêm as características de mobilidade social e os movimentos migratórios. Reconhecer sua cultura e respeitá-la, através de uma convivência de maneira participativa nas decisões sobre os usos das áreas naturais que ocupam, é fundamental para sua existência (Ladeira, 1995)

Já os "caiçaras" representam uma população que tem um tipo de vida característico, sempre vivem perto do mar, de onde sai sua principal fonte de alimento, o peixe.

A prática da agricultura foi herdada dos índios, fazendo um rodízio em pequenas áreas desmatadas, as quais são queimadas antes do plantio da mandioca (matéria prima da farinha, alimento diário), feijão e milho. Também fazem o 
plantio próximo a suas casas de culturas perenes como a banana, coqueiros, café e "fruteiras" (termo usado pelos caiçaras), laranja, jaca, manga, fruta pão, abacate, cana, goiaba, pitanga, etc (Siqueira, 1989).

A relação dessa população com a natureza, por longos anos se deu de forma harmoniosa, num processo lento e progressivo de adaptações recíprocas, cujo catalisador é o modo de tratá-la, não como uma coisa, mas como um organismo vivo, responsável pela manutenção e sobrevivência destas pessoas, as quais, o respeitam (Machado, 1988).

A cultura "caiçara" sobreviveu e interagiu a todos os ciclos econômicos que dominaram a economia do país e penetraram no litoral paulista, mantendo sempre uma relação econômica com os centros urbanos, vendendo sua pequena produção excedente da pesca, da roça e de aguardente

Os novos grupos que foram se estabelecendo no litoral paulista, diferiam das populações tradicionais, não possuíndo uma relação íntima com a natureza, demonstraram apenas o interesse em dominá-la, por razões econômicas e práticas, não estabelecendo relações afetivas e de respeito com o meio ambiente em que se instalaram.

"Este foi um período de transição para a economia e cultura caiçara. $\dot{E}$ o momento de ruptura do isolamento onde as transformações econômicas e sócio-culturais começam a se materializar no espaço construído, no espaço de convivência das famílias e nas atividades produtivas. As construções residenciais se multiplicam, o comércio, os serviços de abastecimento $e$ infra-estrutura despertam nas comunidades novas necessidades de consumo. $O$ contato direto com as populações dos centros urbanos passa a delinear outra transformação: a dos hábitos e dos costumes.(..) a atividade pesqueira começa a se dissociar da lavoura e se transformar em 
principal atividade econômica(...) destruindo a antiga autonomia decorrente da auto-suficiència alimentar" (Luchiari 1992).

Hoje em dia grande parte da população caiçara e seus descendentes já estão ligados as atividades urbanas, como caseiros, na construção civil, em órgãos públicos, etc.

Atualmente o grande desafio, é como conciliar interesses econômicos, sociais e culturais, com o ambiente desta região, e recuperar, e atender as comunidades caiçaras e indígenas remanescentes. Sendo que estas, por longos anos, foram o exemplo de relação entre Homem-Natureza, da qual nossa sociedade moderna tanto necessita.

\subsection{4- Turismo}

A beleza da Mata Atlântica do estado de São Paulo com sua serra, cachoeiras, praias, matas, parques, cidades, é cada dia mais um atrativo à sociedade moderna. Esta sociedade moderna se distanciou da natureza e vive em sua grande maioria em centros urbanos de baixa qualidade ambiental (poucas áreas verdes, muitas vezes com poluição acentuada, "stress" no trabalho, trânsito, etc), necessita se deslocar para áreas mais naturais, sendo o litoral o principal alvo para suprir essas necessidades.

Esse fluxo têm sido responsável por profundas transformações nessas regiões, onde por um lado há o crescimento econômico de grupos específicos como construtoras, imobiliárias, operadoras de turismo, comércio e parte da população que de alguma forma presta outros serviços aos turistas, etc. Por outro lado, podemos detectar vários problemas como: a desestruturação das comunidades tradicionais, problemas de lixo, abastecimento de água, atendimento médico, rede de esgoto, etc. Isso se dá principalmente, durante o verão e feriados, onde a população das cidades pode chegar a um aumento de oito vezes, como foi 
o caso da Baixada Santista e cidades da região no início da temporada do verão de 1997, não oferecendo infra-estrutura básica para um grande número de pessoas (Folha de São Paulo, 7 janeiro de 1997).

Essa realidade vem se agravando desde a finalização da rodovia RioSantos, onde o fluxo de turista aumentou, dando acesso a um grande números de pessoas de classes sociais mais baixa, levando à criação do chamado Turismo de Massa, Turismo Social, Turismo Popular, etc, que se concentrou na Baixada Santista. Os novos prefeitos da região, logo que assumiram em janeiro de 1997, lançaram uma ofensiva para bloquear a entrada nas cidades dos ônibus dos chamados turistas de um dia, justificando-se pela falta de infra-estrutura dos municípios e o baixo retorno econômico que estes (turistas) levam para a região. Segundo o jurista Celso Bastos, especializado em direito constitucional, essa medida fere a Constituição e se caracteriza por discriminar turistas de baixa renda (Folha de São Paulo 7 janeiro de 1997).

Situações como essas tendem a se acirrar, frente ao descaso dos governantes e a baixa qualidade de vida dos grandes centros urbanos, onde o lazer em uma área de boa qualidade ambiental está necessariamente associado a viagens para áreas mais conservadas e distantes, sendo que o litoral vem em primeira opção por grande parte da população.

Na década de 60, no governo de Castelo Branco, houve uma preocupação com a organização do turismo no litoral paulista quando ocorreu a aprovação do projeto de construção da Rio-Santos. Com a inauguração da estrada, estava associada a implementação do Projeto TURIS, por uma empresa francesa (que pretendia organizar o espaço litorâneo entre Rio-São Paulo nos mesmos moldes do litoral francês Languedoc-Roussillon), que dividia o litoral em três categorias: 1) privatização das praias 2) hotéis e casas particulares e 3) áreas de camping, reservando as melhores praias para o turismo da categoria 1 . O projeto não deu resultado e proporcionou inúmeras discussões, pois privilegiava as classes de 
maior poder aquisitivo.

Pode-se dizer que um projeto como esse não condiz com a realidade socioeconômica e cultural da região litorânea, pois está centrado em interesses de populações urbanas, não valorizando as populações tradicionais e seu modo de vida, o que deveria ser um princípio básico para o planejamento de uma proposta como essa.

Além da prática do turismo de massa que tomou conta do litoral paulista e deixou grande impacto nas áreas, uma outra forma de turismo vem crescendo no Brasil e nesta região. É o chamado turismo ecológico, ecoturismo, turismo aventura ou turismo ambiental que segundo Ceballos (1992), pode ser definido como:

"segmento do turismo que viaja para áreas naturais relativamente virgens com o objetivo específico de admirar, estudar, desfrutar da paisagem, de suas plantas $e$ animais, assim como dos aspectos culturais do passado e do presente desta áreas (...) é falar de um turismo que tem uma responsabilidade com o meio ambiente"

O referido autor destaca ainda que os benefícios em relação ao turismo convencional são vários, pois promove a conservação ambiental, incrementa a economia das comunidades tradicionais quando estas são envolvidas no processo de planejamento. Com isso a própria Organização Mundial do Turismo está interessada em estimular a prática do ecoturismo, pois se deu conta que o outro turismo tenha chegado ao seu limite, está destruindo o recurso sobre o qual se baseia e depende (Ceballos ,1992).

Mesmo com essa nova modalidade de turismo que tem como princípio a sustentabilidade do ecossistema e das comunidades que nele vivem, ainda estamos distantes em solucionar seus impactos.

Atualmente, entidades ambientalistas não governamentais de vários países, assim como do Brasil, têm se organizado para a prática da certificação de 
produtos provenientes da natureza, com o objetivo de diferenciar os que realmente fazem um trabalho sério, levando em conta as questões ambientais, sociais e econômicas e não apenas propaganda. Com isso, o consumidor consciente pode escolher um produto de boa qualidade. Desta forma são várias as áreas que já possuem a certificação como o setor florestal, agrícola e outras que se iniciam onde o turismo ambiental se insere.

A certificação do turismo ambiental ainda é insipiente no mundo e no Brasil, mas caminha nesta direção. São inúmeros exemplos negativos da ação do turismo em diversas partes do mundo, e principalmente no Brasil, onde a especulação imobiliária e o acúmulo de turistas degradam sócio-ambientalmente inúmeras áreas.

O Brasil possui hoje grande número de agências e locais que promovem atividades turísticas, auto nomeando-se de Turismo Ambiental, que de ambiental só tem a área visitada, pois grande parte destes grupos promovem atividades de grande impacto, não só no ambiente, mas nas comunidades tradicionais da região.

O Turismo Ambiental deve possuir uma concepção mais ampla, onde a sustentabilidade das atividades e das áreas em uso tenham um caráter fundamental. É uma nova filosofia de ação planejada que promove, não só o contato dos turistas com áreas naturais, mas o conhecimento e a educação ambiental que possibilitem assumir atitudes positivas em relação a esses ambientes.

Estabelecer princípios e critérios e iniciar a certificação do Turismo Ambiental para diferentes regiões do Brasil e do mundo parece ser a maneira mais adequada e justa de valorizar programas que se preocupam com a sustentabilidade. Esse esforço deve ser, não apenas das agências e grupo envolvidos, mas do governo, universidades e consumidores em geral. 


\subsection{Conservação e Recuperação da Mata Atlântica}

\subsection{1- Unidades de Conservação}

Em 1876, quatro ano após a criação do primeiro Parque Nacional do mundo (Yellowstone, nos EUA), deu-se a primeira manifestação pela criação de unidades semelhantes no Brasil: Parque Nacional de Sete Quedas e Ilha do Bananal, por André Rebouças. Em 1911, o próprio Rebouças foi responsável pela elaboração do Decreto $\mathrm{n}^{0}$ 8.843, que criava, no então território do Acre, uma Reserva Florestal de 2,8 milhões de hectares, porém, tal decreto não foi aprovado (FUNATURA, 1989 apud Diegues et al, 1995).

O primeiro Parque no Brasil, o Parque Estadual da Cidade de São Paulo, foi criado em 1896 e só em 1937 foi criado o primeiro Parque Nacional do Brasil e também o Parque Nacional do Itatiaia. Logo em seguida, em 1939, foram criados: o Parque Nacional do Iguaçu e o Parque Nacional da Serra dos Órgãos, (Diegues et al, 1995).

No Estado de São Paulo, em 1911, foi criado, através do Decreto n 2.304 , o Serviço Florestal, que foi estruturado somente em 1945. Em 1970 o Serviço Florestal se transforma em Instituto, pelo Decreto $\mathrm{n}^{\circ} 52.370$, sendo este responsável até hoje, pela administração das Unidades de Conservação no Estado, (Diegues et al, 1995).

Segundo Milano (1990), o Brasil possuía 32.376.025 ha de unidades de conservação somente a nível federal, sendo que o Estado de São Paulo, em 1989, possuía 3.486.503,40 ha, equivalente a $14 \%$ da área do Estado (Tabela 9). Mas essas unidades só irão cumprir suas reais funções para a conservação quando forem devidamente regulamentadas e desenvolverem trabalhos de participação e educação com seus moradores e as comunidades vizinhas. 
Tabela 9. Distribuição das áreas naturais protegidas (ha)do estado de São Paulo

\begin{tabular}{|l|r|}
\hline \multicolumn{1}{|c|}{ TIPO DE ÁREA NATURAL } & \multicolumn{1}{c|}{ ÁREA (ha) } \\
\hline Áreas Naturais Tombadas & $1.338 .289,85$ \\
\hline Áreas de Proteção Ambiental (APAS) & $2.566 .312,20$ \\
\hline Áreas de Relevante Interesse Ecológico (ARIES) & $1.493,64$ \\
\hline Áreas Sob Proteção Especial (ASPES) & $4.620,00$ \\
\hline Estação Ecológica & $106.043,44$ \\
\hline Parques & $758.159,38$ \\
\hline Reservas Biológicas & $2.300,60$ \\
\hline Reservas Florestais & $47.991,74$ \\
\hline $\begin{array}{l}\text { Total de áreas protegidas excluindo-se as } \\
\text { superposição }\end{array}$ & $3.486 .503,40$ \\
\hline
\end{tabular}

Fonte: Secretaria do Meio Ambiente, 1989.

O Instituto Florestal administra 80 unidades, que atingem uma área de 851.547.94 ha, equivalente a 3\% da área do estado de São Paulo, concentrando-se ao longo das escarpas da Serra do Mar e no vale do rio Ribeira de Iguape (Brito, 1995).

A história de estabelecimento das unidades de conservação do Estado de São Paulo se assemelham às condições problemáticas das unidades de conservação federais que são:

a) falta de critérios tecno-científicos para a escolha de áreas prioritárias e desenho do limite da área criada;

b) necessidade premente de resguardar porções de terra com vegetação natural, antes de serem completamente "anexadas" ao processo de desenvolvimento econômico;

c) necessidade de estabelecimento de unidades em áreas de domínio público, e "livre de uso";

d) uso de categorias de manejo que não privilegiam totalmente a realidade das 
áreas onde as unidades foram estabelecidas.

Essas medidas adotadas para a criação das unidades de conservação têm gerado uma série de problema de gestão o que se reflete, atualmente, como o descaso e a expulsão de muitas famílias que já viviam na área antes da criação das unidades. Estima-se a presença de mais de 2.500 famílias em unidades de conservação localizadas no litoral e vale do Ribeira (Brito, 1995)

Segundo Diegues (1996), isso ocorre devido a existência de uma crença e imposição de neomitos (a natureza selvagem intocada), vindo de um modelo norte-americano de unidades de conservação, não se adequando à realidade dos trópicos, onde as florestas e as áreas naturais são habitadas. Isso tem gerado graves conflitos com as comunidades tradicionais, desconsiderando o grande conhecimento do mundo natural que eles possuem. Essas comunidades foram capazes de criar engenhosos sistemas de manejo da fauna e da flora, protegendo, conservando e até potencializando a diversidade biológica.

Devido à grande concentração das unidades de conservação estar na Mata Atlântica e principalmente pela importância que esta representa, foi criada em 1992 a Reserva da Biosfera da Mata Atlântica. Essa reserva abrange três corredores principais: o maior segue ininterrupto pelas Serras do Mar e Geral, do Rio de Janeiro ao Rio Grande do Sul, com cerca de $1.500 \mathrm{~km}$ de extensão, o segundo acompanha a serra da Mantiqueira e o terceiro abrange áreas do sul da Bahia e fragmentos isolados, especialmente áreas do Nordeste (Consórcio Mata Atlântica, 1991).

As Reservas da Biosfera, são criadas pela UNESCO através do programa Homem e Biosfera (MAB), e desenvolvido com o Programa das Nações Unidas para o Meio Ambiente (PNUMA) e a União Internacional para a Conservação da Natureza (UICN), como um instrumento de conservação e sua função inclui o uso sustentável dos recursos naturais nas áreas protegidas.

Essas Reservas devem representar os ecossistemas característicos da região 
onde se estabelecem. Devem ser um centro de monitoramento, pesquisas, educação ambiental e gerenciamento de ecossistema, bem como centro de formação e desenvolvimento profíssional dos técnicos em seu manejo.

Segundo Guatura et al (1994), hoje são mais de trezentas Unidades de Conservação na área de abrangência da Província Florestal Atlântica, com uma área de aproximadamente dois milhões de hectares, onde cerca de dois terços é de propriedade do Estado, embora não de todo regularizado e com graves conflitos fundiários. De acordo com o autor, resolver essas questões e implantar, em definitivo, essas Unidades de Conservação, é tarefa das mais urgentes e prioritárias para garantir a integridade do processo de conservação da Mata Atlântica.

Podemos destacar as principais unidade de conservação da Mata Atlântica como:

Parque Estadual Carlos Botelho

Parque Estadual da Ilha Anchieta

Parque Estadual da Ilha Bela

Parque Estadual da Ilha do Cardoso

Parque Estadual de Jacupiranga

Parque Estadual do Alto do Ribeira

Parque Estadual da Serra do Mar

Nucleo Caraguatatuba

Núcleo Cubatão( A./Pilões)

Núcleo Cunha

Núcleo Curucutu

Núcleo Indaia

Núcleo Itanhaém

Núcleo Itariru

Núcleo Natividade da Serra 
Núcleo Pedro de Toledo

Núcleo Picinguaba

Núcleo Rio Branco-Cubatão

Núcleo São Vicente

Núcleo Serra do Mar-São Bernardo

Estação Ecológica Juréia-Itatins

\subsection{2- Pesquisas na Mata Atlântica}

Grande maioria das pesquisas desenvolvidas na Mata Atlântica tem se concentrado em áreas básicas do conhecimento científico, seja ela social ou ambiental. Isso se dá devido a pouca informação sobre este ambiente tão complexo, e por outro lado, à dificuldade no desenvolvimento da pesquisa aplicada. Para o desenvolvimento desse tipo de pesquisa já não basta apenas um objeto de estudo em uma situação específica, mas sim o estudo de um todo mais complexo de interrelações para podermos concluir, e assim interagir de uma maneira mais prática ("manejar") com o objeto em estudo.

Segundo Brito (1995), grande parte das pesquisas que se dá nas unidades de conservação, há um predomínio das pesquisas básicas em detrimento às aplicadas, e poucas dessas pesquisas têm auxiliado na gestão das unidades, pois seu foco esta centrado em temas bastante específicos, com particularidades de insetos, plantas ou animais.

Outro problema é a capacidade do pessoal técnico das unidades,em acompanhar as pesquisas, seja pela especificidade ou profundidade do assunto, seja pela inexistência e a falta de disponibilidade de técnicos para fazê-lo, pois muitas vezes são absorvidos por atividades administrativas e burocráticas das unidades, não tendo tempo para a pesquisa.

Num levantamento de trabalhos na área de fitossociologia na Mata Atlântica do Brasil, desenvolvido por Siqueira (1994), conseguiu-se relacionar 
192 referências, onde sessenta por cento ocorreram a partir de 1975, devido ao aumento de cursos de pós-graduação no país, aos programas a longo prazo do governo federal, aos convênios entre instituição de pesquisa e empresas particulares, e à instalação dos centros e unidades regionais de pesquisa da EMBRAPA.

A Região Sudeste contribuiu com mais de $50 \%$ das publicações, particularmente o estado de São Paulo que contribuiu com mais de $30 \%$ do total.

A autora destaca que apesar deste aumento significativo das publicações, o montante ainda é pequeno e não fornece uma base sólida para uma análise profunda da flora em questão. Contudo, aponta a grande diversidade desta vegetação e a necessidade urgente de se incentivar o aumento da quantidade de publicações para que se possa traçar, o mais fielmente possível, o perfil desta flora, conhecendo-se sua distribuição, associações, relações com o ambiente e propor formas seguras e bem elaboradas de utilizações dos recursos.

Com isso, vemos que a pesquisa básica é de fundamental importância, em especial nesta região, para dar base para ações futuras, mas há uma necessidade ainda mais urgente em se buscar soluções de manejo e conservação a curto e médio prazo, onde a pesquisa aplicada, tem um papel fundamental. 


\subsection{3- Legislação Ambiental}

Em 1764, foram assinadas por D. João VI medidas que proibiam o corte de Mangue, reservando-o a extração de tanino. (Diegues, 1990 apud Diegues et al, 1995). Mas foi Maurício de Nassau quem tomou as primeiras medidas de cunho ambientalista no século XVIII, visando evitar a derrubada das florestas do Nordeste “... para não vir a faltar algum dia às necessidades públicas" (FUNATURA, s/d apud Diegues et al,1995). Na Carta Régia de 1797, segundo (Quintão, 1983:19 apud Diegues et al, 1995), alertava ser “...necessário tomar preucauções para a conservação das mattas do Estado do Brasil, e evitar-se que ellas se arruinem e se destruam...".

No século XI ocorrem ações mais concretas, devido às pressões, no Rio de Janeiro. Com isso foram baixados vários Decretos Reais para a proteção dos mananciais ameaçados. Em 1833, criou-se a Reserva de Florestas através da Decisão Imperial $\mathrm{n}^{\circ} 429$, e em 1861, foram criadas a Floresta da Tijuca e a Floresta Palmeira. Também ocorreram neste período, manifestações de personalidades esclarecidas, como José Bonifácio, que sugere a criação de um setor administrativo responsável pelas Matas e Bosques (IBDF/FBCN, 1981a apud Diegues et al, 1995).

A legislação ambiental no Brasil tem seu primeiro Código Florestal em 1934, (Decreto $\mathrm{n}^{\circ}$ 23.793), e vem sofrendo grandes mudanças ao longo desses anos, procurando se adequar à realidade ambiental brasileira (Quintão, 1983:19 apud Diegues et al, 1995).

Em 28 de fevereiro de 1967 é criado através do Decreto-Lei número 289, o Instituto Brasileiro de Desenvolvimento Florestal (IBDF). A finalidade de tal instituto era formular a política florestal, bem como orientar, coordenar, executar ou fazer executar as medidas necessárias: à utilização racional, à proteção e à conservação dos recursos naturais renováveis e ao desenvolvimento florestal do 
País, de conformidade com a legislação em vigor.

A legislação ambiental brasileira é considerada bastante completa e rigorosa, quando comparada a outros países, mas apesar de seu avanço, a sua aplicação se restringe na prática. Segundo Ventura (1996), a legislação necessita ser aperfeiçoada, fazendo com que alguns de seus dispositivos deixem de ser utópicos, adequando-os à conservação do meio ambiente sem o sacrificio das atividades produtivas, como vem ocorrendo atualmente.

No Estado de São Paulo, a Lei que regulamenta o uso da Mata Atlântica está no Decreto número 750, de 10 de fevereiro de 1993, que dispõe sobre o corte, a exploração e a supressão de vegetação primária ou nos estádios avançados e médio de regeneração, assim como outras providências. Esse decreto considera a área de ocupação da Mata Atlântica, não só a região litorânea do Estado, como definido neste trabalho, mas também prolongamentos em direção ao interior. $O$ decreto menciona diferentes tipos de vegetações como: a Floresta Ombrófila Densa (Mata de Encosta), Mata de Restinga, Mangues ( em momento algum é mecionada a vegetação de Dunas, cometendo um erro apesar das poucas áreas no Estado). Tal decreto também cita as vegetações que se prolonga ao interior do Estado como: Florestas Estacionais, Florestas Ombrófilas Mistas (Pinhais), Campos e Cerrados.

Além da legislação, um fator de extrema importância na conservação da Mata Atlântica que vem avançando e conseguido resultados positivos é a organização popular através de entidades não governamentais (ONGs), as quais, muitas vezes, desempenham o papel de interlocutores entre a comunidade e orgãos competentes do governo. Respaldadas nas leis, recebem e fazem denúncias de agressão ao meio ambiente, elaboram, financiam e desenvolvem projetos na área social, ambiental e econômica da Mata Atlântica.

Os fatores da degradação dos ambientes naturais não se restringem apenas à falta de conhecimento e técnicas na maioria dos casos. O fator principal é o tipo 
de organização social, com seu modo de vida e interesses, o que irá ser fator determinante no tipo de uso e relação com ambientes naturais

“... organização social o elemento chave na explicação de porque certas sociedades atingem formas de exploração dos recursos naturais renováveis que lhe permitem se reproduzir sem destruir irremediavelmente o meio ambiente enquanto que outras desenvolvem processos produtivos altamente predatórios e comprometedores das forças produtivas" (Godelier, 1973 Apud Diegues, 1983). 


\section{4-MATERIAL E MÉTODOS}

\section{1- Área de Estudo}

A área de estudo do presente trabalho denomina-se Mata Atlântica do estado de São Paulo. Para vários autores, esta área se engloba à região praiana, a serra e prolongamentos para o interior do Estado (Rizzini 1963, Romriz 1972). Outros autores, Joly et al (1991), Leitão Filho (1982), definem sua distribuição como restrita à faixa litorânea. Este trabalho irá concentrar seus estudos no Litoral Paulista tendo como limite a região geográfica do Estado de São Paulo drenada diretamente para o Oceano Atlântico. O limite é a linha de cumeada do divisor de águas que separa as bacias hidrográficas da vertente marítima e da vertente que demanda o interior paulista, delimitando-se com os Estados do Paraná a sudoeste, e Rio de Janeiro a noroeste.

A área abordada no presente trabalho possui $21.564 \mathrm{~km}^{2}$ e abrange aproximadamente $9 \%$ do território paulista, englobando integralmente os territórios de vinte e oito municípios e parcialmente outros sete. De acordo com a Fundação de Sistema Estadual de Análise de Dados (SEADE, 1995):

- vinte e cinco municípios pertencem à Região Administrativa $n^{0}-2$ - Litoral;

- seis à $n^{0}-4$ - Sorocaba (Apiaí, Barra do Turvo, Iporanga, Ribeira, Tapiraí e Ibiúna);

- quatro a $n^{0}$-1 - Região Metropolitana de São Paulo-RMSP (Juquitiba, Itapecerica da Serra e Biritiba-Mirim, Ibiuna). 
Na região litorânea, os municípios são agrupados em sub-regiões:

- Vale do Ribeira e Litoral Sul (Apiaí, Eldorado, Barra do Turvo, Jacupiranga, Pariquera-Açu, Sete Barras, Registro, Juquiá, Miracatu, Iguape, Ilha Comprida e Cananéia, Tapiraí, Iporanga, Ribeira);

- Litoral Norte (São Sebastião, Bertioga, Caraguatatuba, Ubatuba e Ilha Bela);

- Baixada Santista (Santos, São Vicente, Cubatão, Guarujá, Bertioga, Praia Grande, Mongaguá, Itanhaém, Peruíbe, Itariri e Pedro de Toledo).

Além dos municípios pertencentes à Região Metropolitana de São Paulo, (Juquitiba, Itapecerica da Serra e Biritiba-Mirim, Ibiúna), que se situam parcialmente na região litorânea.

\section{2- Metodologia de Trabalho}

Neste trabalho o envolvimento de professores e alunos se dá no processo de concepção do protótipo do CD-ROM quanto aos tópicos a serem abordados e a maneira como eles podem ser disponibilizados. A participação é direta, através da sugestão de temas de interesses e uma análise do protótipo do CD-ROM, bem como, indicando mudanças para facilitar a navegação e a introdução de novos conteúdos.

O envolvimento de estudantes e professores ocorre de forma parcial, em algumas etapas do trabalho, tais como: preenchimento de questionários e análise do protótipo do CD-ROM.

Em se tratando do ensino-apredizagem da informática educativa, acreditase que mesmo com a participação ocasional dos futuros usuários, esse programa reflete grande parte das necessidades e interesses do público alvo sobre o tema da Mata Atlântica.

Segundo Maciel et al (1995), quando se fala em informática educativa, está-se propondo desenvolver um processo didático através de mecanismos tecnológicos modernos e não meramente a utilização do computador. A sua 
contribuição é ser um instrumento, meio de ensino e não apenas o ensino de computação e de suas linguagens. A informática educativa tem como base instigar a compreensão, a interação e a crítica do aluno.

Pode-se destacar que este protótipo de CD-ROM, além de ser um banco de dados sobre os tópicos relativos à Mata Atlântica, deve instigar a reflexão, de forma a estimular a participação e a visão crítica da realidade. Para isso buscou-se listar diferentes temas sobre à Mata Atlântica: as ONG's que atuam na área, bibliografias relativas à Mata Atlântica e os órgãos do governo responsáveis pela questões socio-econômica, cultural e ambiental da região.

Além dos tópicos relativos a Mata Atlântica buscou-se elaborar um jogo de desafio sobre a vegetação da região, onde o usuário, a partir de um problema de degradação ambiental apresentado, deve propor uma solução para recompor a vegetação.

O processo de desenvolvimento do protótipo também pode ser uma contribuição importante na metodologia de produção destes tipos de CD-ROM temáticos, onde há um envolvimento de professores e alunos no processo de sugestão e análise do produto, pois há uma demanda crescente na criação e aplicação desses materiais nas escolas.

\section{3- Fases do Trabalho}

Nos itens a seguir serão abordadas as etapas de desenvolvimento do presente trabalho, que constam de fases distintas, sendo que a maioria ocorreu concomitantemente. Inicialmente, houve um estudo da multimídia, para se inteirar sobre o que tem sido feito e a forma como vem sendo desenvolvido os aplicativos em multimídia. Em seguida, deu-se início a coleta e processamento dos dados sobre o tema abordado, assim como, a definição do público alvo. Com base neste público, elaborou-se e aplicou-se um questionário na busca de mapear seus interesses e necessidades. A partir das informações já coletadas e da análise dos 
questionários, criou-se um protótipo do CD-ROM.

De posse do protótipo foi o mesmo aplicado a uma amostra de alunos, os quais puderam analisar e sugerir inovações para uma futura finalização do CDROM. Juntamente com o protótipo foi criado e aplicado um jogo através de um desafio, onde o usuário utilizou as informações disponíveis no protótipo para solucionar um problema.

\subsection{1- $O$ estudo de Multimídia}

Como os aplicativos multimídia representam algo bastante recente no Brasil e nas universidades, foi necessário investigar o assunto de forma a obter o conhecimento básico que possibilitasse a realização de um protótipo de multimídia. Assim, além da consulta bibliográfica e contatos com profissionais da área, foi feito um curso básico sobre multimídia no Departamento de Multimeios da Universidade Estadual de Campinas (UNICAMP). Houve também a necessidade de participação de um curso específico de programação em multimídia, usando o software Tool Book 4.0, oferecido pela Escola do Futuro/ USP (Núcleo de Pesquisa das Novas Tecnologias de Comunicação Aplicada à Educação).

Além desses cursos, foi necessário o estudo sobre digitalização de imagens e sons, bem como o estudo dos respectivos software para edição dos referidos materiais. Para a captura e edição das imagens utilizou-se o Adob Photo Shop e Photo Paint, e para os sons utilizou-se aplicativos da Sound Blaster.

\subsection{2- Definição do público alvo}

A definição do público alvo ao qual se destina o programa foi fundamental, pois, baseando-se nos seus interesses e nível de conhecimento, foi planejado o conteúdo, detalhada a linguagem e a abordagem dos temas do protótipo do CDROM. 
Inicialmente, pensava-se em trabalhar apenas com alunos de $2^{0}$ grau, de $1^{0}$ e $2^{0}$ colegial, tendo em vista o melhor aproveitamento do conteúdo do protótipo, devido ao estágio escolar mais avançado, mas optou-se também por incluir alunos do $1^{0}$ grau a partir da $7^{\mathrm{a}}$ série, pois o tipo de linguagem pretendida para elaboração do protótipo valorizava as imagens, com textos objetivos, de fácil compreensão.

\subsection{3- $A$ aplicação do questionário}

A utilização do questionário, (segue na próxima página) teve como objetivo o levantamento de parâmetros sobre o conhecimento e interesses dos alunos para auxiliar na adequação do protótipo do CD-ROM da Mata Atlântica. Da mesma forma, foi elaborado um questionário para os professores, para obter informações de suas carências e necessidades em tratar o tema em suas propostas escolares.

A aplicação do primeiro questionário se deu, anterior ao contato de professores e alunos com o protótipo do CD-ROM. Nesta etapa participaram 133 alunos pertencentes a diferentes séries $\left(7^{\mathrm{a}}\right.$ e $8^{\mathrm{a}}$ série, $1^{0}$ e $2^{0}$ colegial), e apenas 5 questionários, dos 20 entregues, foram respondidos pelos professores de diferentes disciplinas.

O questionário foi aplicado no $1^{0}$ colegial do Colégio Anglo Campinas e na $7^{\mathrm{a}}$ e $8^{\mathrm{a}}$ série, $1^{0}$ e $2^{0}$ colegial do Colégio Anglo de Itapira. A escolha destas escolas foi devido ao interesse demonstrado pela direção em auxiliar a pesquisa, e a disponibilidade de equipamentos (computadores multimídia) para finalizar a pesquisa. 


\section{Questionário para os alunos}

nome- série- idade-

1-Você já ouviu falar na Mata Atlântica?

2-Onde fica a Mata Atlântica do Estado de São Paulo?

3-Você conhece algum tipo de vegetação da Mata Atlântica do Estado de São Paulo?

4-Você sabe quem vive na Mata Atlântica?

5-Que atividade eles desenvolvem para viver?

6-O que tem sido feito para recuperar e conservar a Mata Atlântica?

7-Que informação você acha importante e gostaria de ter sobre a Mata Atlântica?

\section{Questionário para os professores}

nome

disciplina que leciona

série

1-O que você acha mais interessante na Mata Atlântica?

2-Você aborda temas sobre Mata Atlântica em sala?

3-Quais as informações que você considera importantes ao se abordar o tema sobre a Mata Atlântica

4-Quais as maiores dificuldades e carências em abordar temas sobre a Mata Atlântica?

\subsection{4- A coleta de dados}

A realização do protótipo $\mathrm{CD}-\mathrm{ROM}$ da Mata Atlântica foi definida, inicialmente, com a abordagem de cinco temas principais: localização e mapas, tipos de vegetação, ocupação, conservação e recuperação e banco de informações. Sendo que o banco de informação consta de: bibliografía para consulta, sobre os diversos tema da Mata Atlântica e as ONGs e orgãos governamentais que atuam na área.

Para a abordagem de tais temas á coleta de dados se concentrou na compilação de textos, imagens e sons, e por se tratar de um assunto vasto, com 
informações dispersas, a coleta e a seleção do material foi bastante trabalhosa.

\subsection{5- O processamento dos dados}

Após reunir cerca de 3 mil imagens em cromo ("slides"), grande quantidade de textos e alguns sons específicos para o protótipo do CD-ROM da Mata Atlântica, foi necessária uma seleção minuciosa e trabalhosa, de forma a valorizar a qualidade visual e abordar o assunto com objetividade, sem torná-lo superficial. Após a seleção das imagens, textos e sons, os mesmos foram processados em softwares específicos, conforme especificação abaixo:

\subsection{5a- texto-}

Para a edição de textos foi utilizado o software Word 6.0 for Windows

\subsection{5b- imagem-}

Em primeiro lugar, foi necessário digitalizar a imagem, ou seja, colocá-la dentro do computador, através de um scanner de slides para o qual foi utilizado um Nikon-Coolscan II numa resolução de 300 dpi. Para imagens de mapas foi utilizado um scanner de mesa da HP numa resolução de 100 dpi. Depois de digitalizada, o ajuste da imagem foi feito através de softwares específicos para o trabalho, o Photo Paint do Corel Draw, e o Adobe Photo Shop.

\subsection{5c-.som-}

Foi utilizado o software da Sound Blaster para gravar as narrações, mixar e editar o som.

\subsection{5d- gráficos e tabelas-}

Foram utilizados os aplicativos Word, Exel e Harvard Graphic. 
4.3.5e- aplicativo de multimídia-

Esse foi o aplicativo responsável por agrupar e organizar toda mídia, que iria compor o protótipo do CD-ROM, de acordo com o objetivo do projeto. Neste projeto utilizou-se o software Multimídia Tool Book 4.0, que é um aplicativo com grandes recursos, utilizados em trabalhos profissionais.

\subsection{6- A elaboração do protótipo do CD-ROM da Mata Atlântica (Anexo B)}

A partir dos dados coletados e das informações obtidas através dos questionários, elaborou-se um roteiro de trabalho com o uso de um fluxograma (consta a seguir), que norteou a montagem do protótipo. 


\section{Fluxograma para o CD-ROM}

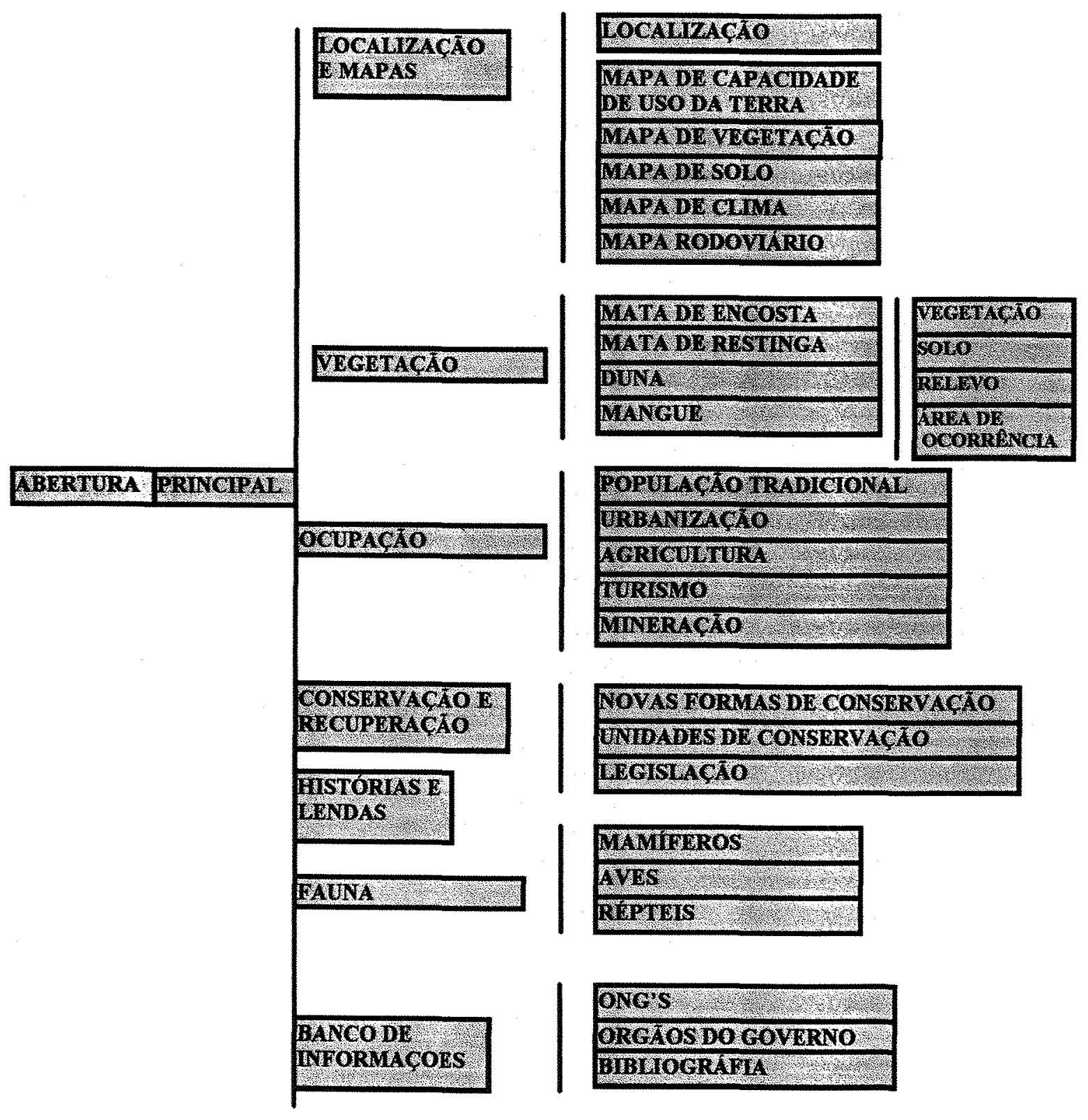


Considerando-se a concepção inicial deste trabalho o conteúdo do protótipo foi ampliado. Além dos cinco tópicos definidos inicialmente (Tipos de Vegetação, Localização e Mapas, Ocupação, Conservação e Recuperação e Banco de Informações) foram incluídos dois novos tópicos: Fauna, Historias e Lendas e um subtópico Mineração, o qual faz parte da Ocupação da Mata Atlântica.

Alguns tópicos foram desenvolvidos parcialmente, como é o caso Tipos de Vegetação e Banco de Informações, já os demais tópicos foram apenas listados para um desenvolvimento futuro, como pode-se observar no Anexo B.

\subsection{7- A utilização do protótipo}

A atividade de utilização do protótipo se concentrou em uma classe de 21 alunos do $2^{0}$ colegial técnico em informática, do Colégio Anglo de Campinas, por um período de 4 horas de duração. Num primeiro contato com os alunos foi explicado como estava sendo desenvolvido o projeto do CD-ROM, seus objetivos e a importância da participação da classe na análise do protótipo. O protótipo foi mostrado num telão para a classe, no dia posterior à exposição do projeto. Ao final da atividade cada aluno fez diversas sugestões por escrito com base em um questionário entregue aos mesmos (a seguir).

\section{Questionário para os alunos após o uso do Protótipo}

Com base no protótipo do CD-ROM da Mata Atlântica que você acabou de ver, gostaria que me ajudasse a detectar os pontos positivos, as falhas e descrever algumas sugestões para que ele possa ser melhorado.

1- O que você acha que deve ser alterado no CD-ROM?

2- Qual outro tópico seria interessante abordar no CD-ROM?

3- Nos tópicos que foram listados, mas ainda não desenvolvidos, o que você gostaria de encontrar.

4- Gostaria que você me ajudasse, a criar um desafio ou jogo sobre a Mata Atlântica. Fazendo uso das informações disponíveis no CD-ROM, o que você propõe? 


\subsection{8- Aplicação do desafio}

Na elaboração do CD-ROM prevê-se a criação de alguns jogos, através de desafios que contemplem o conteúdo abordado nos tópicos do CD-ROM, no intuito de motivar os usuários, colocando-os em situações que possibilite utilizar seus conhecimentos de maneira mais ampla e integrada na solução do problema.

Para testar a viabilidade do desafio, como elemento integrante do protótipo do CD-ROM, foi desenvolvido um experimento que previa o uso do protótipo pelos usuários para resolução de uma situação problema. $O$ objetivo era identificar os fatores (conteúdo do CD-ROM) que os alunos levam em conta para apresentar a solução de uma determinada situação. Para isso foi criado um desafio sobre os diferentes tipos de vegetação da Mata Atlântica. A partir de uma situação problema (página: 65), um grupo de três alunos, após o uso do protótipo, deveria apresentar uma solução para recompor os diferentes tipos de vegetação da região abordada na atividade. Para isso os alunos deveriam utilizar elementos que deveriam compor a paisagem. Tais elementos eram representados através de fotografias com legendas referentes: ao relevo, ao solo, à vegetação, ao rio e ao mar (Anexo C).

Para a apresentação da solução da situação problema, o grupo deveria dispor os elementos sobre uma cartolina representando um mapa esquemático da região.

Todo esse processo de aplicação do desafio foi filmado para realização de uma análise posterior da atividade. A avaliação desse experimento possibilitou a checagem da viabilidade de disponibilização do desafio no protótipo do CDROM, assim como a obtenção de parâmetros mais claros para melhorar sua qualidade. 


\section{Situação Problema}

Você está prestes a ganhar uma fazenda no litoral paulista, com uma área que vai desde o alto da serra até a beira do mar.

Um senhor de idade quer fazer a doação, mas tem um probleminha que você terá de resolver para conseguir a fazenda.

Por muitos anos este senhor, utilizou a vegetação da fazenda, para venda da madeira e outros usos, não restando mais nada atualmente. Hoje ele está arrependido, pois, a fazenda além de perder toda a beleza que possuía, os animais haviam sumido e o solo descoberto (sem vegetação) estava se degradando com enormes erosões, devido as fortes chuvas da região.

Para este senhor the doar a fazenda, você tem que recompor a vegetação, da maneira mais primitiva possível (como a vegetação era antes de ser cortada). Para isso você terá uma cartolina com o desenho de um rio e do mar representando o mapa da fazenda. Você deve dividir a cartolina em quatro partes, cada parte deve corresponder aos diferentes tipos de vegetação original existente na área: Mata de Encosta, Mata de Restinga, Mangue e Dunas. Sobre cada parte você terá que dispor três elementos específicos que irão compor a paisagem. Os elementos são: relevo, solo e vegetação, também terá dois elementos complementares: o mar e o rio. Os elementos estão representados através de fotos com suas respectivas legendas (Anexo C).

Desta forma você terá recomposto a vegetação da fazenda através de um mapa, mas você ainda não é dono da fazenda. Antes de você receber a escritura, um engenheiro florestal irá verificar se a divisão e a disposição dos elementos da paisagem sobre o mapa será sustentável ao longo dos anos. Se por exemplo você colocou corretamente os elementos da paisagem em duas partes do mapa, VIVA! $50 \%$ da fazenda já é sua, e você ainda terá mais uma chance de refazer sua solução para ficar com toda a fazenda. Para isso o engenheiro florestal irá lhe indicar qual a área que você necessita recuperar. Pense, pesquise e encontre solução.

Boa sorte, lembre-se a fazenda pode ser sua !!! 


\section{5- RESULTADOS E DISCUSSÕES}

Os resultados e discussões aqui apresentados se baseiam nas coletas de dados obtidas através dos questionários aplicados aos 133 alunos e 5 professores e da aplicação do protótipo do CD-ROM aos 21 alunos, assim como a análise da "desafio" proposta aos três alunos. A partir da coleta dos dados e análise dos mesmos foi possível mapear interesses e necessidades do público alvo ao se abordar o tema Mata Atlântica do estado de São Paulo através de um CD-ROM.

\section{1- Resultados da aplicação dos questionários}

Com a aplicação do questionário para os alunos de $7^{\mathrm{a}}$ e $8^{\mathrm{a}}$ série do $1^{0}$ grau , foi possível tabular os dados de acordo com a Tabela 10 , assim como os de $1^{0}$ e $2^{0}$ colegial do $2^{0}$ grau na Tabela 11. 
Tabela 10. Resultado da aplicação de questionário sobre a Mata Atlântica aos alunos de $1^{0}$ grau, em uma escola na cidade de Itapira-SP

\begin{tabular}{|c|c|c|}
\hline perguntas & $\begin{array}{l}7^{\text {a }} \text { série } \\
\text { Itapira } \\
25 \text { alunos }\end{array}$ & $\begin{array}{l}8 \text { aćrie } \\
\text { Itapira } \\
25 \text { alunos }\end{array}$ \\
\hline $\begin{array}{l}\text { 1 Vocè já ouviu falar na } \\
\text { Mata Atlântica? }\end{array}$ & $100 \% \mathrm{~S}$ & $100 \% \mathrm{~S}$ \\
\hline $\begin{array}{l}2 \text { Onde fica a Mata } \\
\text { Atlântica do Estado de } \\
\text { São Paulo? }\end{array}$ & $\begin{array}{l}52 \% \mathrm{~L} ; 32 \% \mathrm{NS} ; 8 \% \mathrm{~S} / \mathrm{M} ; 4 \% \\
\mathrm{AM} ; 4 \% \mathrm{~L} / \mathrm{N}\end{array}$ & $\begin{array}{l}64 \% \mathrm{~L} ; 20 \% \mathrm{NS} ; 12 \% \mathrm{~S} / \mathrm{M} ; 4 \% \\
\mathrm{~L} / \mathrm{N}\end{array}$ \\
\hline $\begin{array}{l}3 \text { Você conhece algum } \\
\text { tipo de vegetação da } \\
\text { Mata Atlântica do } \\
\text { Estado de São Paulo? }\end{array}$ & $\begin{array}{l}68 \% \mathrm{NS} ; 8 \% \mathrm{~F} / \mathrm{L} ; 8 \% \mathrm{H} ; 16 \% \\
\text { O (tropical, cerrado, pau } \\
\text { brasil,bananeira) }\end{array}$ & $\begin{array}{l}58 \% \text { NS; } 12 \% \mathrm{~S} ; 30 \% \mathrm{O} \text { (veg. } \\
\text { atlântica, grandes árvores, floresta } \\
\text { fechada, caducifoliadas, coníferas, } \\
\text { caatinga, cerrado, hidrófila) }\end{array}$ \\
\hline $\begin{array}{l}4 \text { Você sabe quem vive } \\
\text { na Mata Atlântica? }\end{array}$ & $\begin{array}{l}44 \% \text { NS; } 24 \% \mathrm{I} ; 20 \% \text { A; } 8 \% \\
\mathrm{~A} / \mathrm{I} ; 4 \% \mathrm{E} / \mathrm{F}\end{array}$ & $\begin{array}{l}48 \% \text { NS; } 16 \% \mathrm{~A} ; 12 \% \text { A/P } 8 \% \mathrm{I} \\
16 \% \text { O (macaco, elefante, leão, } \\
\text { ninguém) }\end{array}$ \\
\hline $\begin{array}{l}5 \text { Que atividade eles } \\
\text { desenvolvem para viver? }\end{array}$ & $\begin{array}{l}52 \% \mathrm{NS} ; 16 \% \mathrm{AG} ; 16 \% \mathrm{C} / \mathrm{P} \\
16 \% \mathrm{O} \text { (derrubam árvores para } \\
\text { fazer papel, extrativismo) }\end{array}$ & $\begin{array}{l}64 \% \text { NS; } 12 \% \mathrm{C} ; 8 \% \mathrm{C} / \mathrm{P} ; 16 \% \\
\text { (predação, extração de madeira, } \\
\text { extrativismo) }\end{array}$ \\
\hline $\begin{array}{l}6 \text { O que tem sido feito } \\
\text { para recuperar e } \\
\text { conservar a Mata } \\
\text { Atlântica? }\end{array}$ & $\begin{array}{l}52 \% \text { NS; } 12 \% \text { C/C; } 36 \% \mathrm{O} \\
\text { (reflorestamento, leis, reservas, } \\
\text { grupos de defesa, projetos, } \\
\text { proibição da derrubada e } \\
\text { gueimada) }\end{array}$ & $\begin{array}{l}48 \% \mathrm{NS} ; 24 \% \mathrm{C} / \mathrm{C} ; 8 \% \mathrm{R} ; 8 \% \mathrm{~N} \\
12 \% \text { O (multas, grupos de apoio, } \\
\text { programas culturais) }\end{array}$ \\
\hline $\begin{array}{l}7 \text { Que informação você } \\
\text { acha importante e } \\
\text { gostaria de ter sobre a } \\
\text { Mata Atlântica? }\end{array}$ & $\begin{array}{l}32 \% \text { sobre as perguntas, } 16 \% \\
\text { habitantes, } 12 \% \text { área, } 8 \% \mathrm{NS}, \\
32 \% \text { O ( Porque é importante?, } \\
\text { O que acontece se for } \\
\text { destruída?, Esta acabando?, } \\
\text { quem e o que tem sido feito } \\
\text { para recuperar? }\end{array}$ & $\begin{array}{l}28 \% \text { sobre as perguntas, } 4 \% \\
\text { espécies de animais e plantas, } 68 \% \\
\text { O (área, Como era antes do Brasil } \\
\text { ser descoberto?, O que a SOS Mata } \\
\text { Atlântica esta fazendo tem dado } \\
\text { resultado?, Quando a mata estará } \\
\text { destruída se desmatamento } \\
\text { continuar?, Gostaria de saber mais } \\
\text { sobre a mata) }\end{array}$ \\
\hline
\end{tabular}

Legenda S- Sim; NS- Não Sabe; L- Litoral; S/M- Serra da Mantiqueira, AM- Amazônia, L/N- Litoral Nordestino, F/L- Floresta Latifoliada, H- Hidrófila, O- Outros, I- Índios, A- Animais, A/I- Animais e Índios, E/F- Exploradores da Floresta, AG- Agricultura, C/P- Caça e Pesca, C- Caça, C/C- Campanhas de Conscientização, N- Nada; R- Reflorestamento, A/P- Animais e Plantas. 
Tabela 11. Resultado da aplicação de questionário sobre a Mata Atlântica a alunos de 2 graus, em duas escolas nas cidades de Campinas e ItapiraSP

\begin{tabular}{|c|c|c|c|}
\hline perguntas & $\begin{array}{l}1^{0} \text { colegial } \\
\text { Itapiira } \\
4 \text { alunos }\end{array}$ & $\begin{array}{l}1^{\prime} \text { colegial } \\
\text { Campinas } \\
15 \text { alumos }\end{array}$ & $\begin{array}{l}2^{0} \text { colegial } \\
\text { Itapira } \\
2+\text { alumos }\end{array}$ \\
\hline $\begin{array}{l}1 \text { Você já ouviu falar na } \\
\text { Mata Atlântica? }\end{array}$ & $100 \% \mathrm{~S}$ & $100 \% \mathrm{~S}$ & $100 \% \mathrm{~S}$ \\
\hline $\begin{array}{l}2 \text { Onde fica a Mata } \\
\text { Atlântica do Estado de } \\
\text { São Paulo? }\end{array}$ & $66 \% \mathrm{~L} ; 34 \% \mathrm{NS}$ & $93 \% \mathrm{~L} ; 7 \% \mathrm{~S} / \mathrm{M}$ & $96 \% \mathrm{~L} ; 4 \% \mathrm{NS}$ \\
\hline $\begin{array}{l}3 \text { Você conhece algum } \\
\text { tipo de vegetação da } \\
\text { Mata Atlântica do } \\
\text { Estado de São Paulo? }\end{array}$ & $\begin{array}{l}43 \% \mathrm{NS} ; 20 \% \mathrm{~S} ; 11 \% \\
\mathrm{~F} / \mathrm{L} ; 5 \% \mathrm{M} ; 20 \% \mathrm{O} \\
\text { (veg. costeira, veg. alta e } \\
\text { fechada, veg. } \\
\text { heterogênea, } \\
\text { seringueira, hidrófila, } \\
\text { pau brasil, trepadeiras) }\end{array}$ & $\begin{array}{l}47 \% \text { orquídea; } 33 \% \text { ipê, } \\
\text { cedro, peroba; } 13 \% \\
\text { bananeira: } 7 \% \text { eucalipto; } \\
13 \% \text { NS }\end{array}$ & $\begin{array}{l}38 \% \mathrm{~S} ; 29 \% \mathrm{~F} / \mathrm{L} ; 4 \% \\
\text { árvores; } 4 \% \text { mogno; } \\
13 \% \text { floresta; } 13 \% \text { NS }\end{array}$ \\
\hline $\begin{array}{l}4 \text { Você sabe quem vive } \\
\text { na Mata Atlântica? }\end{array}$ & $\begin{array}{l}39 \% \text { NS; } 16 \% \text { A; } 16 \% \\
\text { A } \mathrm{Ps} ; 5 \% \mathrm{I} ; 11 \% \mathrm{~S} ; 11 \% \\
\mathrm{O} \text { (pessoas que } \\
\text { exploram madeira, } \\
\text { látex, venda de } \\
\text { caranguejo, siri e peixe) }\end{array}$ & $\begin{array}{l}60 \% \mathrm{~A} ; 13 \% \mathrm{C} c ; 13 \% \mathrm{I} \\
7 \% \mathrm{NS}\end{array}$ & $\begin{array}{l}21 \% \text { NS; } 17 \% \mathrm{~S} ; 21 \% \\
\text { A; } 13 \% \text { AVP; } 8 \% \text { pobres } \\
\text { e leigos; } 4 \% \mathrm{I} ; 4 \% \\
\text { estudiosos, } \\
\text { trabalhadores em } \\
\text { madeira e escultores; } \\
4 \% \text { pessoas }\end{array}$ \\
\hline $\begin{array}{l}5 \text { Que atividade eles } \\
\text { desenvolvem para viver? }\end{array}$ & $\begin{array}{l}41 \% \text { NS; } 16 \% \text { Ex; } 16 \% \\
\text { C/P; } 9 \% \text { predação; } 11 \% \\
\text { O (cadeia alimentar, } \\
\text { trabalho com madeira e } \\
\text { borracha) }\end{array}$ & $\begin{array}{l}60 \% \operatorname{Pr} ; 7 \% \mathrm{C} / \mathrm{P} ; 13 \% \\
\mathrm{P} ; 7 \% \mathrm{Ex} ; 14 \% \mathrm{NS}\end{array}$ & $\begin{array}{l}50 \% \mathrm{NS} ; 21 \% \mathrm{Ex} ; 13 \% \\
\mathrm{C} / \mathrm{A} ; 8 \% \text { alimentam-se; } \\
4 \% \text { fotossintese; } 4 \% \\
\text { agricultura de } \\
\text { subsistência }\end{array}$ \\
\hline $\begin{array}{l}6 \text { O que tem sido feito } \\
\text { para recuperar e } \\
\text { conservar a Mata } \\
\text { Atlântica? }\end{array}$ & $\begin{array}{l}32 \% \mathrm{R} ; 32 \% \mathrm{NS} ; 16 \% \\
\mathrm{~N} ; 5 \% \mathrm{C} / \mathrm{C} ; 5 \% \mathrm{Rs} ; 5 \% \\
\text { proibição da derrubada e } \\
\text { queimada de árvores }\end{array}$ & $\begin{array}{l}47 \% \text { N; } 20 \% \text { NS; } 20 \% \text { R: } \\
7 \% \text { Rs; } 7 \% \text { instituição } \\
\text { Xuxa Meneguel }\end{array}$ & $\begin{array}{l}29 \% \mathrm{R} ; 29 \% \mathrm{NS} ; 25 \% \\
\mathrm{~N} ; 13 \% \mathrm{C} / \mathrm{C} ; 8 \% \mathrm{Rs}\end{array}$ \\
\hline
\end{tabular}

Nota: continua próxima página

Legenda S- Sim; NS- Não Sabe; L- Litoral; S/M- Serra da Mantiqueira, AM- Amazônia, L/N- Litoral Nordestino, F/L- Floresta Latifoliada, H- Hidrófila, O- Outros, I- Índios, A- Animais, A/I- Animais e Índios, E/F- Exploradores da Floresta, AG- Agricultura, C/P- Caça e Pesca, P- Pesca, Pr- C- Caça, C/CCampanhas de Conscientização, N- Nada; R- Reflorestamento, A/P- Animais e Plantas, A/Ps- Animais e Pessoas, Pr- Predação 


\section{Continuação da Tabela}

Tabela 11. Resultado da aplicação de questionário sobre a Mata Atlântica aos alunos de $2^{0}$ grau, em duas escolas nas cidades de Campinas e Itapira-SP

\begin{tabular}{|c|c|c|c|}
\hline perguntas & $\begin{array}{l}1^{n} \text { colegial } \\
\text { Itapira } \\
+4 \text { alunos }\end{array}$ & $\begin{array}{l}1^{0} \text { colegial } \\
\text { Campinas } \\
15 \text { alunos }\end{array}$ & $\begin{array}{l}2^{1} \text { colegial } \\
\text { Itapira } \\
24 \text { alunos }\end{array}$ \\
\hline $\begin{array}{l}7 \text { Que informação você } \\
\text { acha importante e } \\
\text { gostaria de ter sobre a } \\
\text { Mata Atlântica? }\end{array}$ & $\begin{array}{l}14 \% \text { como ajudar na } \\
\text { conservação; } 9 \% \text { NS; } \\
5 \% \text { sobre as perguntas; } \\
10 \% \text { Animais e Plantas; } \\
62 \% \text { O (no que ela } \\
\text { favorece nossa vida?, O } \\
\text { que tem sido feito para } \\
\text { recuperar?, Quais os } \\
\text { perigos de aumentarem } \\
\text { seus problemas e } \\
\text { consequentemente os } \\
\text { nossos, no futuro?, } \\
\text { Poderia ser doado lotes } \\
\text { para os sem terra?, Os } \\
\text { guardas-florestais } \\
\text { conseguem manter o } \\
\text { controle de toda área }\end{array}$ & $\begin{array}{l}33 \% \text { NS } \\
20 \% \text { sobre as espécies de } \\
\text { animais e plantas } \\
13 \text { \% o que tem sido feito } \\
\text { para preservar } \\
7 \% \text { importância da } \\
\text { preservação de áreas } \\
\text { nativas } \\
7 \text { \% que porcentagem } \\
\text { ocupa do Brasil } \\
13 \% \text { sobre as perguntas } \\
7 \% \text { tempo de duração da } \\
\text { vegetação }\end{array}$ & $\begin{array}{l}30 \% \text { como conservar } \\
17 \% \text { NS } \\
17 \% \text { sobre as espécies } \\
\text { de animais e plantas } \\
13 \% \text { é possível } \\
\text { recuperar } \\
15 \% \text { outras } \\
8 \% \text { sobre as perguntas } \\
\end{array}$ \\
\hline
\end{tabular}

Legenda S- Sim; NS- Não Sabe; L- Litoral; S/M- Serra da Mantiqueira, F/L- Floresta Latifoliada, OOutros, I- Índios, A- Animais, C/P- Caça e Pesca, C/C- Campanhas de Conscientização, RReflorestamento, A/P- Animais e Plantas, Rs- Reservas, M- Mangue, A/Ps- Animais e Pessoas, ExExtrativismo, Pr- Predação; P- Pesca; Cç- Caiçara; C/A- Cadeia Alimentar

Podemos destacar quanto a primeira questão que todos os alunos tanto de $1^{0}$ como $2^{0}$ grau já tinham conhecimento sobre a Mata Atlântica, provavelmente devido a grande divulgação nos meios de comunicação, e também pelo fato de muitos desses alunos já terem ido passar férias nesta região.

Na segunda questão, que se refere a localização da Mata Atlântica, há uma diferenciação entre os alunos de $1^{0}$ e $2^{0}$ grau ocorrendo um gradiente diversificado de conhecimento sobre a localização da Mata Atlântica na região litorânea. Esse gradiente se inicia com $52 \%$ de respostas corretas na $7^{\text {a }}$ série, chegando a $96 \%$ no $2^{0}$ colegial. Isso pode estar relacionado com a abordagem do referido conteúdo 
nas diversas séries, bem como, uma maior vivência dos alunos em visitas à região.

Quando questionados sobre o tipo de vegetação que ocorre na Mata Atlântica, $68 \%$ dos alunos de $7^{a}$ série não souberam responder. Já nas demais séries ocorre uma diminuição, chegando a $13 \%$ no $2^{0}$ colegial. Dos alunos que responderam a questão, pode-se observar a dificuldade e a falta de clareza com relação ao conceito de vegetação, pois a grande maioria confunde tipo de vegetação com espécies arbóreas. Vários alunos citaram diferentes nomes de árvores, sendo que muitas não ocorrem na Mata Atlântica como: mogno, seringueira, eucalipto. Alguns alunos tinham conhecimento do conceito de vegetação, mas, vários deram nomes de vegetações de regiões distintas do estado de São Paulo e dos limites da área da Mata Atlântica, como: caatinga e cerrado.

As respostas dadas a esta questão nos leva a refletir sobre os motivos da dificuldade ocorrida em relação ao conceito de vegetação. A raiz do problema pode estar na falta de uma material didático adequado, e também na estrutura de ensino compartimentalizada, não situando os alunos num contexto mais amplo da realidade.

Com relação à ocupação da Mata Atlântica, temos uma variedade de afirmações, em sua maioria corretas, mas limitadas e presas a uma leitura da mata primitiva, revelando uma visão parcial da realidade local. Dos alunos do $1^{0}$ grau, $46 \%$ não souberam responder. Já no segundo grau esta porcentagem cai para $30 \%$, o que pode estar relacionado à abordagem do tema nas aulas lecionadas.

$\mathrm{Na}$ quinta questão, que indaga como vive a população da região, há uma similaridade de respostas com a questão anterior que também focalizava o assunto sobre ocupação da região. Porém em relação à questão anterior houve uma aumento dos que não souberam responder, sendo $58 \%$ no $1^{0}$ grau e $50 \%$ no $2^{0}$ grau. Isso mostra que em questões correlacionadas os alunos fazem inferências a partir de relações estabelecidas entre os assuntos, o que aponta para a importância da construção de uma rede de informações que facilite o estabelecimento de 
correlação entre diferentes assuntos.

$\mathrm{Na}$ sexta questão, relativa às atividades de recuperação e conservação da Mata Atlântica, tanto os alunos de primeiro como os de segundo graus, citaram diversas atividades semelhantes e na maioria corretas. Foram destacadas as reservas florestais, as iniciativas de reflorestamento $e$ as campanhas de conscientização para a conservação do meio ambiente. Isso mostra a importância da divulgação de atividades de conservação através dos meios de comunicação que atingem grande parte da população escolar. Apesar do conhecimento revelado por alguns alunos quanto as iniciativas de conservação da Mata Atlântica, há ainda um grande número de alunos do primeiro grau, $50 \%$, que não souberam responder a questão. Já no segundo grau esse índice reduziu para $27 \%$.

A sétima questão, relativa aos interesse dos alunos sobre Mata Atlântica, foi bastante esclarecedora, para o presente estudo, pois aponta para vários aspectos importantes como:

1- O interesse dos alunos em conhecer mais sobre o tema, mesmo não sabendo especificar quais são eles.

2- Buscam-se argumentações sobre a importância da Mata Atlântica para o ser Humano.

3- Busca-se uma maior compreensão da situação atual com relação à épocas anteriores, quantificando a degradação do ambiente, visando traçar um quadro futuro da situação se as iniciativas adequadas não forem efetivadas.

4- Buscam-se inferir as consequências das ausências de medidas para frear o desmatamento.

5- Buscam-se informações sobre propostas de conservação já em andamento.

6- Busca saber se ainda há solução para o problema e quais seriam, e o que poderia ser feito para ajudar.

7- Buscam-se informações sobre as iniciativas de conservação da Mata Atlântica propostas pelos profissionais e entidades responsáveis pela área 
8- Buscam-se informações sobre o tempo necessário para o desenvolvimento da vegetação com o reflorestamento

9- Busca-se informação sobre elementos que compõem a Mata Atlântica tais como: animais, plantas, populações, etc.

De maneira geral o conhecimento dos alunos tanto de primeiro como de segundo grau, sobre a Mata Atlântica, quando correto, é fragmentado. As dúvidas e a vontade de conhecer mais sobre o assunto é grande. Assim sendo, a utilização do CD-ROM da Mata Atlântica nas escolas pode contribuir para ampliar a abordagem do assunto de forma mais global e crítica, com informações mais próximas da realidade, sendo apresentados de uma maneira motivadora e interativa.

Para os professores também foi aplicado o questionário, sendo que os dados obtidos foram tabulados na Tabela 12 (abaixo).

Tabela 12. Resultado da aplicação do questionário a 5 professores do Colégio Anglo de Itapira-SP

\begin{tabular}{|l|l|}
\hline \multicolumn{1}{|c|}{ Perguntas } & \multicolumn{1}{|c|}{ Respostas } \\
\hline $\begin{array}{l}\text { 1- O que você acha de mais } \\
\text { interessante na Mata Atlântica? }\end{array}$ & $\begin{array}{l}\text { diversidade de plantas e animais, mata mais } \\
\text { próximas da região mais desenvolvidas do país e } \\
\text { a mais devastada }\end{array}$ \\
\hline $\begin{array}{l}\text { 2 Você aborda temas sobre Mata } \\
\text { Atlântica em sala? }\end{array}$ & sim (todos) \\
\hline $\begin{array}{l}\text { 3-Quais as informações que você } \\
\text { considera importantes ao se abordar o } \\
\text { tema sobre a Mata Atlântica? }\end{array}$ & $\begin{array}{l}\text { devastação, extinção de animais, conscientizar } \\
\text { para preservação, extensão que ocupa, } \\
\text { programa de conservação governamental e não } \\
\text { governamental, conseqüência da devastação }\end{array}$ \\
\hline $\begin{array}{l}\text { 4-Quais as maiores dificuldades e } \\
\text { carências em abordar temas sobre a } \\
\text { Mata Atlântica? }\end{array}$ & falta de informações \\
\hline
\end{tabular}


Os professores que responderam o questionário lecionavam as disciplinas de: português, geografia, química, física, inglês. Esses professores demonstraram ter interesse e apontaram a importância em se abordar temas como: a diversidade de plantas e animais; a degradação devido à proximidade dos grandes centros urbanos; os programas de conservação e a conscientização sobre o meio ambiente.

Um dos itens limitantes, apontados pelos professores quanto uma ampla abordagem do tema em sala de aula é a falta de informação e a carência de materiais didáticos. Isso aponta para á necessidade em se desenvolver estes materiais, de forma a auxiliar os professores na abordagem do tema, que estejam direcionados para:

1- Uma visão ampla da realidade, destacando seus problemas e as iniciativas para solucioná-los.

2- Uma abordagem destacando diferentes elementos da Mata Atlântica, principalmente a grande diversidade de plantas e animais da região.

Com base nos resultados da aplicação desses questionários para professores e alunos pôde-se tirar importantes pontos para a montagem de uma nova versão do protótipo do CD-ROM tais como:

1- Um maior detalhamento do interesse do público alvo sobre os tópicos abordados.

2- A indicação de novos tópicos ao protótipo como: Fauna, Histórias e Lendas e Mineração, sendo que esses dois últimos itens foram incluídos com base nas pesquisa de campo.

\section{2- Resultados da aplicação do Protótipo}

A aplicação do protótipo contou com a participação de 21 alunos do $2^{0}$ colegial. Cada item do protótipo foi apresentado num telão (Figura 1), e as dúvidas dos alunos foram respondidas. Após a apresentação do protótipo os alunos fizeram anotações com base no questionário (abaixo) entregue aos 
mesmos.

\begin{tabular}{|l} 
Questionário para os alunos após o uso do Protótipo \\
Com base no protótipo do CD-ROM da Mata Atlântica que você acabou de ver, \\
gostaria que me ajudasse a detectar os pontos positivos, as falhas e descrever algumas \\
sugestões para que ele possa ser melhorado. \\
1- O que você acha que deve ser alterado no protótipo do CD-ROM? \\
2- Qual outro tópico seria interessante abordar no protótipo do CD-ROM? \\
3- Nos tópicos que foram listados, mas ainda não desenvolvidos, o que você gostaria de \\
encontrar. \\
4- Gostaria que você me ajudasse, a criar um desafio ou jogo sobre a Mata Atlântica. \\
Fazendo uso das informações disponiveis no protótipo do CD-ROM, o que você propõe?
\end{tabular}

Através das anotações realizadas pelos alunos foi possível detectar os pontos fracos e colher valiosas sugestões para melhorar a interação do programa com o usuário através da navegação, bem como, listar novos tópicos, desafios e jogos de interesse. 


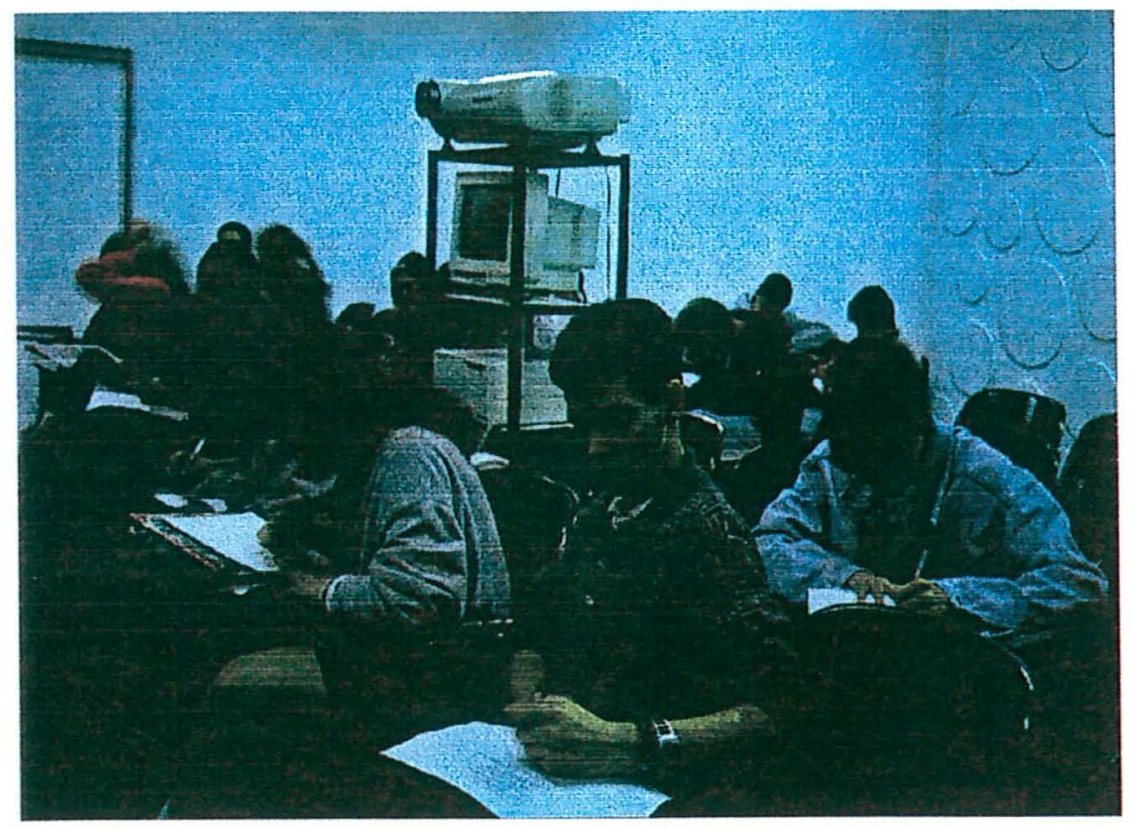

Figura 1 - Aplicação do protótipo para a classe

Comparando-se com a fase de aplicação do questionário no início da elaboração do protótipo do CD-ROM, essa dinâmica de envolvimento dos alunos na análise do protótipo mostrou-se bastante eficiente, tendo um ganho em qualidade e quantidade, pois, permitiu que os alunos demonstrassem seus interesses mais detalhadamente. Isso possibilitou além da abordagem referente aos conteúdo dos tópicos, o surgimento de várias sugestões com relação ao sistema de navegação, e sua qualidade gráfica.

Para ilustrar esse fator podemos tomar como exemplo um dos itens mais sugeridos para fazer parte do CD-ROM: os animais e as plantas da Mata Atlântica. O grupo de alunos no qual foi aplicado apenas o questionário, demonstraram somente o interesse em conhecer espécies de animais e plantas, já no grupo onde foi aplicado o protótipo, estes fizeram sugestões mais detalhadas como: animais e plantas em extinção, animais e plantas aquáticas, plantas medicinas, suas características, uso e nome científico.

Com isso pode-se observar a importância em consultar o público alvo 
durante as diversas fases do desenvolvimento do trabalho, sendo que, neste caso em específico, o público alvo foi alunos de primeiro e segundo grau.

Esta atividade de consulta possibilitou a confirmação de uma importante dinâmica de trabalho, a qual enriquece a qualidade de produção de um CD-ROM, onde o foco das atenções durante o trabalho não está apenas no produto, mas também no processo de produção e no contexto em que será utilizado.

Também, o detalhamento obtido nesta atividade quanto aos interesses e às expectativas em relação ao protótipo, proporcionou a inclusão de novas idéias de melhoria para uma implementação futura.

Abaixo podemos listar as diversas sugestões colhidas com a aplicação do protótipo.

\section{Sugestões para melhorar o protótipo}

1- Na abertura do CD-ROM incluir um vídeo ou animação.

2- Colocar vídeos para demonstrar itens como relevo.

3- Colocar animação ou vídeo no tópico histórias e lendas.

4- Incluir músicas típicas de caiçaras e índios.

5- Usar som do Chico Science, pássaros, cachoeiras, etc.

6- O menu ter uma barra com todas as opções disponíveis, inclusive a de tirar o som.

7- Incluir depoimentos das populações tradicionais, turistas e moradores.

8- Usar mapas reais para destacar a região da Mata Atlântica.

9- Opções de pesquisas relacionando diferentes tópicos.

10- Usar cores discretas nos botões.

11- Inserir as explicações e curiosidades através de hipertextos.

12- Utilizar a transição de tela para tornar mais agradável a utilização do programa.

13- Modificar os botões e barras de rolagem não deixando-os com "design" parecido ao programa windows. 
Dentro destas sugestões podemos definir importantes pontos para 0 planejamento das ações na elaboração de um CD-ROM tais como:

- Uso de diferentes mídias como: texto, som, vídeo, imagens, animação, de forma representativa dos assuntos tratados

- Projetar "design" e interface diferenciados do padrão usual dos aplicativos e mais próximo do assunto tratado.

- Dar recursos para o usuário monitorar o ambiente de navegação, retomar suas ações, desfazê-las, poder ativar e desativar alguns recursos quando quiser.

- Uso de hipertexto para disponibilizar informações em diferentes níveis de abrangência, prevendo a correlação de informações em tópicos diferentes.

- Com o uso de vídeo disponibilizar informações mais contextualizadas com a realidade.

\section{Novos tópicos}

1- Os rios da Mata Atlântica.

2- Curiosidades sobre a região e informação sobre como prevenir a destruição da Mata Atlântica.

3- Animais e plantas aquáticos.

4- Plantas medicinais: característica, uso, nome científico, etc.

5- Animais e plantas em extinção.

6- Poluição.

As sugestões desses novos tópicos reflete a necessidade em se tratar os temas escolhidos de forma mais detalhada, possibilitando ao usuário conhecer o assunto em maior profundidade. 


\section{Novos desafios e jogos}

1- Criar uma cadeia alimentar com elementos da fauna.

3- Jogos de adivinhação, usando fotos referentes a região.

4- Jogo onde a pessoa tem que impedir a destruição das matas.

5- Quebra cabeça e caça palavras.

6- Jogo de memória: fazer os pares das imagens e a descrição correspondente.

Os novos desafios e jogos sugeridos demonstram o interesse por esse tipo de atividade, a qual além de motivar a consulta sobre os temas, possibilita ao usuário utilizar as informações adquiridas, tornando-as mais próximas de sua realidade

Também foi possível constatar o interesse dos alunos pelo CD-ROM da Mata Atlântica como podemos observar nas frases abaixo, descritas pelos alunos. "Eu gostei muito deste trabalho"

"Gostei de tudo, tá falando sobre animais, vegetação, tem fotos lindas, tá bom" "A sua idéia de criar esse CD-ROM foi muito boa..."

"Gostei muito deste CD-ROM. A idéia é excelente para a educação..."

Outro aspecto importante que se confirma na aplicação do protótipo é o interesse do usuário pelas características audiovisuais do programa, como imagens e sons de boa qualidade e textos reduzidos, como podemos observar na frase abaixo de um dos alunos.

"Tudo que o usuário quer ver é imagem, vídeo e escutar som e músicas, coloque textos, mas com uma voz narrando-o".

\section{3- Resultados da aplicação do Desafio}

A aplicação do desafio contou com a participação de três alunos. Num primeiro momento, os alunos se inteiraram do aplicativo navegando nas opções disponíveis do protótipo.

Posteriormente foi apresentado a situação problema (ver em Aplicação do 
desafio página-65), que constava de um texto explicativo, um mapa esquemático da área e figuras com legendas, representando elementos da natureza.

Com base nos materiais disponíveis e com a possibilidade de consultar o protótipo sobre os itens que integravam a situação problema, os alunos apresentaram uma solução.

Todo o processo de resolução do desafio foi gravado em vídeo de forma a facilitar a análise posterior.

Ao iniciar a resolução do desafio o grupo separou os elementos mais fáceis, rio e mar, e a partir deles, foi dispondo os demais elementos associando-os de acordo com sua proximidade. Perto do mar colocaram a areia, o relevo plano, e a vegetação rasteira de duna, no outro extremo colocaram a serra com sua mata de encosta. Próximo ao rio alocaram o mangue, e, o relevo intermediário, foi colocado entre serra e mar. A partir deste ponto tiveram dificuldade para distribuir os diferentes tipos de solos e a vegetação de restinga. Para obter informações dos elementos que estavam em dúvida, passaram a consultar o protótipo do CD-ROM (Figura 2) e após várias consultas conseguiram finalizar o desafio apresentando uma solução (Figura 3). A solução apresentada pelo grupo, foi discutida com a presença de um engenheiro florestal, o qual avaliou como correta a solução proposta ao problema. 


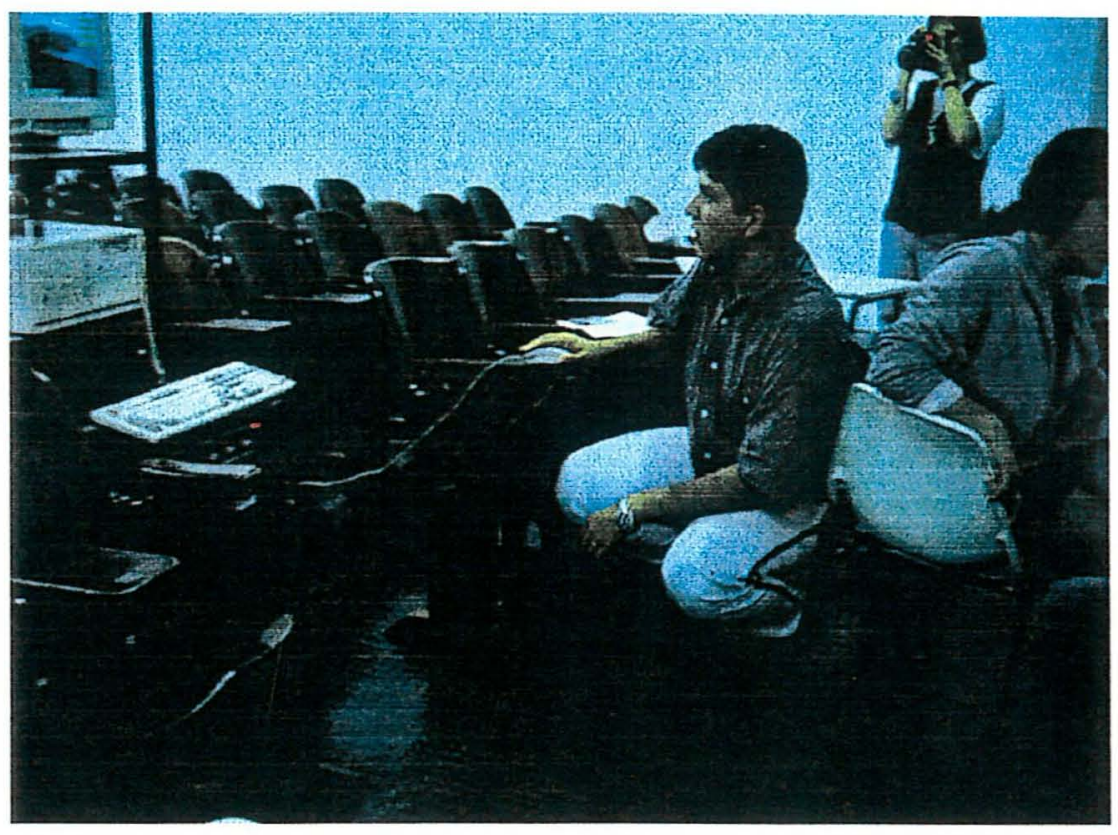

Figura 2 - A consulta ao protótipo do CD-ROM

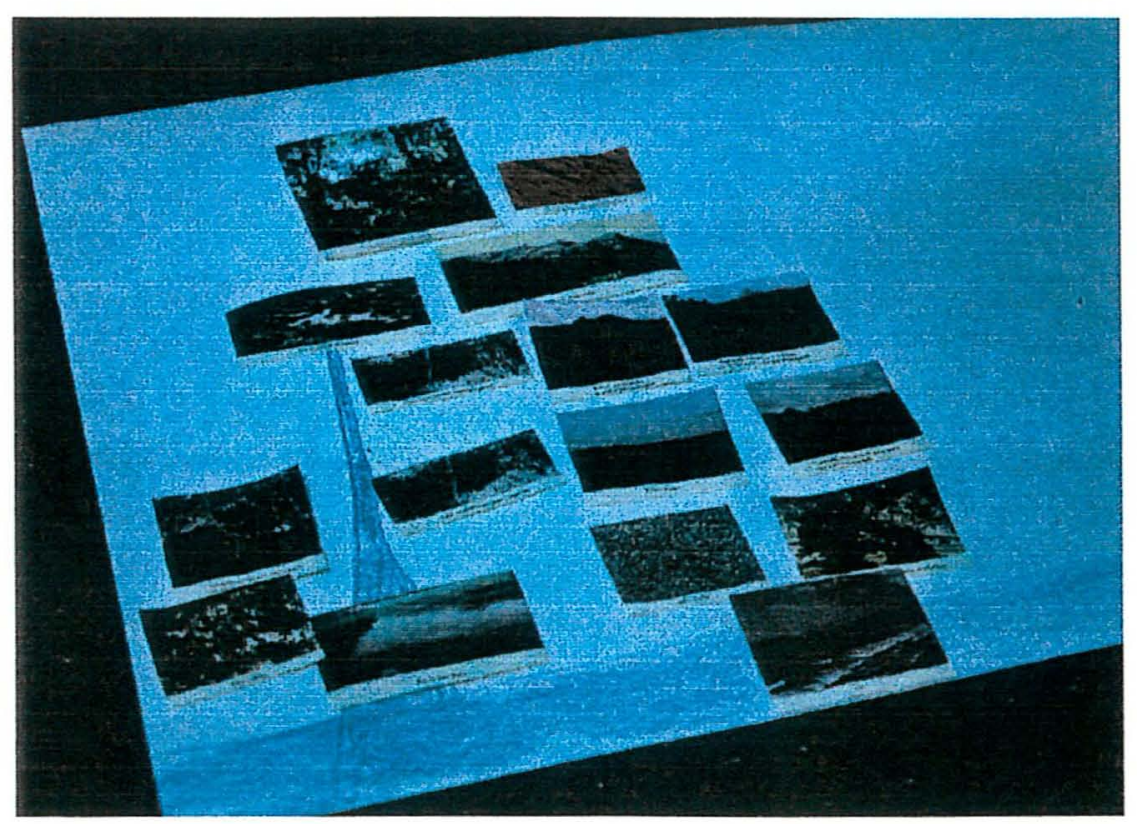

Figura 3 - Resultado da resolução do desafio (mapa esquemático) 
A forma como é proposto o desafio, através de uma pequena estória, tendo como estímulo a possível conquista da fazenda, proporcionou um entusiasmo por parte dos alunos. Ao final do experimento os alunos propuseram a entrega da "escritura" da fazenda em papel, para o usuário que conseguisse apresentar uma solução correta para o desafio.

A prática do desafio mostrou-se bastante importante, estimulando a busca de soluções de problemas, através da discussão em grupo, e através do uso do protótipo para a consulta de informações necessárias, para tomada de decisões relevantes no contexto. A atividade do desafio possibilitou a utilização das informações de maneira conjunta, de forma concreta na solução de problema. Com isso foi possível estimular a assimilação dessas informações e a criação de uma visão mais ampla do contexto tratado, e das relações entre os elementos que integram o mesmo.

A frase abaixo, extraída de um dos questionários, ilustra o que os alunos estão interessados com relação ao desafio.

"Desafio não seja composto de perguntas como: Qual o clima da Mata Atlântica?, mas sim, um desafio que forneça descontração."

A descontração a que o aluno se refere, pode ser interpretada como um distanciamento do modelo formal de ensino, com perguntas sobre conceitos que pouco acrescentam, a não ser o cansaço e o tempo gasto na memorização das respostas.

Abaixo podemos listar algumas das sugestões referentes ao desafio vivenciado pelos alunos.

\section{Sugestões para melhorar o desafio}

1- Colocar um atalho para facilitar a pesquisa do conteúdo do protótipo do CDROM na solução do desafio, possibilitando um fácil acesso aos tópicos e as imagens referentes aos elementos que integram a situação problema.

2- No desafio da fazenda além de inserir a vegetação incluir a fauna e a 
população.

3- No desafio da fazenda as fotos devem focalizar apenas o elemento referente à legenda, não deixando aparecer outros elementos da paisagem na mesma foto. Por exemplo na foto do mar não deixar aparecer a areia ou o céu.

4- Se a pessoa acertar o desafio, ela deve ganhar uma escritura no final, impressa em papel. 


\section{6- CONSIDERAÇÕES FINAIS}

$\mathrm{O}$ desenvolvimento deste trabalho indica vários pontos importantes no processo de produção de um CD-ROM com uma perspectiva educacional onde podem ser destacados alguns tópicos importantes como:

\section{1- Ensino e educação}

- A valorização e a participação do público ao qual se destina o CD-ROM, no processo de análise do material e apresentação de sugestões, é de grande importância, para se obter parâmetros mais claros quanto aos seus interesses e necessidades, orientando assim o desenvolvimento do trabalho. Essa prática pode melhorar a criação de materiais didáticos voltados para educação ambiental, minimizando as grandes falhas que hoje os mesmos possuem (citadas no livro "Avaliando a Educação Ambiental no Brasil: Materiais Impressos" Trajber (1996)).

-O conhecimento dos alunos de $7^{\mathrm{a}}$ série ao $2^{0}$ colegial, a respeito da Mata Atlântica do estado de São Paulo, é bastante fragmentado, sem uma visão global e crítica sobre sua realidade. A utilização de conhecimentos e conceitos relativos aos temas tratados dentro do desafio mostrou a possibilidade do aluno trabalhar as informações de maneira integrada. 
- Os professores abordam o tema (Mata Atlântica) em sala de aula, mas apontam para a falta de materiais e informações. O uso CD-ROM como abordado neste trabalho, pode ser de grande valor para minimizar ou suprir essas necessidades.

\section{2- Dinâmica de desenvolvimento}

- O trabalho de criação e elaboração de um CD-ROM pressupõe a formação de uma equipe, composta por elementos de diversas áreas de conhecimento. Desta forma pode-se otimizar a qualidade do trabalho, quanto a coleta e seleção das informações sobre o tema, "designer" gráfico, e a programação do CD-ROM,

- A necessidade de recursos financeiros para compra de equipamento, programas, material de consumo, pagamento de pessoal, viagens, etc., é imprescindível para um bom andamento do projeto.

\section{3- Para o futuro usuário}

- A participação dos alunos no processo de elaboração e análise do CD-ROM da Mata Atlântica proporcionou um ganho qualitativo e quantitativo nos tópicos abordados, na forma de navegação dentro do protótipo do CD-ROM e no desafio proposto, assim como para a apresentação de novas sugestões.

- O uso do desafio no programa cria grande motivação e interesse dos participantes, pois, coloca o usuário em situação que estimula a reflexão e a pesquisa de informações para encontrar a solução, em um contexto significativo, para a utilização das informações. Esta constatação traz uma nova dimensão não apenas informativa, mas de habilidades, valores e atitudes, através de uma atividade lúdica, que, de acordo com Trajber et al (1996), essa dimensão é necessária e carente nos materiais impressos de educação ambiental. 
- A busca de informações no CD-ROM torna-se mais interessante e motivadora para o usuário quando está associado a desafios. Durante a aplicação do desafio, o grupo de aluno primeiramente navegou pelo CD-ROM e passou por mais de três vezes em alguns itens sobre a vegetação, mas, foi durante a resolução do desafio que o grupo navegou atento aos conteúdos dos itens e com maior motivação, pois queriam encontrar a solução.

- A valorização de imagens com boa qualidade desperta maior interesse e motivação do usuário ao CD-ROM. Esta é uma característica fundamental para atingir o público alvo, e de acordo com Trajber et al (1996), essa é uma das grandes falhas dos materiais didáticos em educação ambiental no Brasil.

- Textos concisos, com frases e alguns parágrafos, em níveis diferentes de abrangência do assunto, são mais motivadores para o usuário durante a navegação. Isso é um ponto importante, a ser considerado pois, a viabilização das informações pode ser disponibilizada de diferentes maneiras, possibilitando uma navegação rápida, inicialmente através de textos concisos e um aprofundamento das informações, nos itens de interesse do usuário, através de hipertextos ou de um banco de informação.

\section{4- As etapas necessárias de elaboração de um Multimídia}

- Definição do tema principal e os subtemas que irão compô-lo

Esse é o principal ponto de partida: ter claro com o que se quer trabalhar, onde se pretende chegar, e como se pretende atingir o objetivo desejado. Para isso, é necessário se ter uma familiaridade com o tema e subtemas ou realizar uma pesquisa prévia para defini-los com maior segurança, evitando problemas futuros. 
- Público alvo (crianças, adolescentes, adultos, instituições públicas/privadas, centros urbanos/periferia, zona rural, etc.)

Com público alvo definido será mais fácil optar pelo tipo de linguagem e abordagem do tema. Para esse trabalho, o público alvo foi alunos a partir da $7^{\mathrm{a}}$ série do $1^{0}$ grau, por possuírem um maior conteúdo escolar o que facilita $o$ entendimento e a utilização do programa de multimídia.

- A participação do público alvo na análise e sugestões dos temas abordados

Essa prática é fundamental quando se deseja criar um CD-ROM que realmente tenha um valor educacional e atinja o interesse do público alvo, pois desta forma é possível adequar os objetivos do CD-ROM com a perspectiva do usuário.

Com base no trabalho realizado mostrou-se importante consultar o usuário em diferentes fases do desenvolvimento, pois otimiza a participação dos mesmos com sugestões mais detalhadas.

- Tipo de linguagem e abordagem ( banco de dados, tutorial (exemplo: jogos, etc.)

Para as diferentes faixas etárias a linguagem e a abordagem deverão ser adequadas e motivadoras, atentando-se para o conteúdo dos temas, com informações precisas e adequadas a cada faixa etária. Seria inútil colocar longos textos de difícil compreensão para criança e adolescente, pois imagens, vídeos, e animação gráfica, estimula muito mais sua atenção. No presente trabalho utilizaram-se das imagens e do sons como principal linguagem de um banco de dados interativo. De maneira geral, independente da faixa etária, o usuário de um CD-ROM busca, além das informações, a descontração através de uma boa 
qualidade audiovisual, com isso a qualidade de imagem e som devem ser valorizadas, além das informações é claro.

- Criar um fluxograma com temas, subtemas e os possíveis caminhos

Um fluxograma é fundamental para a visualização de todo o programa, o que auxilia o trabalho de criação e programação.

- Mídias a serem utilizadas (som, imagem (foto, slides, vídeo), texto, animações, etc.)

As mídias são o conteúdo do trabalho (o recheio do bolo, quanto mais elaborado melhor será, mas cuidado, o excesso o torna indigesto), sua qualidade será responsável em se atingir ou não o objetivo proposto. Com isso as diferentes mídias utilizadas, devem ser elaboradas com cuidado e reavaliadas nas diferentes etapas da construção do multimídia, solicitando para isso a colaboração do futuro usuário.

- Coleta e criação de um banco de dados (texto,imagem,etc.)

Essa é uma das etapas mais trabalhosa, pois há necessidade de um volume grande de informações e imagens, sendo que estas estão dispersas em diferentes publicações, órgãos, cidades e regiões, de acordo com o tema abordado. A sistematização da coleta pelo tema e subtemas, facilita a estruturação do banco de dados. 


\section{PERSPECTIVA FUTURA}

Com o desenvolvimento do projeto várias idéias, bem como, novos conhecimentos a respeito da elaboração de programas de multimídia, com a participação do público alvo, foram se formando de maneira a apontar para uma perspectiva futura de trabalho e ação, onde podemos listar:

- Finalização do CD-ROM, com base na coleta de dados realizada junto ao público alvo e a implementação de novas etapas de envolvimento deste publico.

- Implementação de vários desafios dentro do CD-ROM, abordando temas diferenciados, pois este se mostrou bastante positivo no estímulo e participação dos alunos na exploração do conteúdo do CD-ROM.

- Criação de ligações, entre tópicos e temas correlacionados, de forma a facilitar a pesquisa pelo usuário.

- Produção de materiais nesta linha de trabalho, onde se pode destacar um tema importante, como: Conceitos Ambientais. Utilizando-se para isso uma abordagem didática para diferentes públicos, valorizando as imagens e os jogos e possibilitando assim, que o usuário vivencie conceitos com base nos elementos fornecidos no CD-ROM.

- Criação de novos itens no banco de dados, como por exemplo: atividades 
práticas, o qual irá sugerir áreas a serem visitadas na Mata Atlântica, por professores e alunos, estimulando conhecimento "in-loco" dos temas sugeridos nos tópicos, assim como ações práticas que possam desenvolver no colégio.

- Apontar no banco de dados endereços da Internet relacionados com os temas.

- Disponibilização das informações do CD-ROM via Internet.

- Disponibilização do CD-ROM em instituições governamentais e não governamentais. 


\section{8-BIBLIOGRAFIA}

AGOSTINHO, V. Favelização avança no litoral norte de SP. Cotidiano, Folha de São Paulo, 20 de out. 1996. $3^{0}$ Caderno.

ALVES, A.C.; CORRÊA, M.O.S.; OLIVEIRA, C.; BIALOKORSKI, N.S. Programa de Educação Ambiental do Vale do Ribeira: Legislação e Meio Ambiente. Série Educação Ambiental, Secretaria do Meio Ambiente, V. 10, p.36, 1990

ANDRADE , M. A. B. Contribuição ao conhecimento da ecologia das plantas das Dunas do litoral do Estado de São Paulo. Boletim da Faculdade de Filosofia Ciências e Letras, USP 305, Botânica, V.23, p.3-170, 1968.

ARAÚJO, D. S. D.. Restinga : Síntese dos conhecimentos para a costa sul sudeste brasileira In : SIMPÓSIO SOBRE ECOSSISTEMAS DA COSTA SUL E SUDESTE BRASILEIRA, Cananéia, SP, São Paulo:ACIESP, 1987. p. 333-347

BAIDER, C.. O banco de semente e de plântulas na sucessão da Mata Atântica, São Paulo, 1994. 137p. Dissertação ( M.S) - Universidade de São Paulo. 
BARROS, J.P.D. \& D' AMBROSIO, U.. Computadores, Escola e Sociedade,1.ed, São Paulo: Scipione. 1988.

BRITO, M.C.W.. Unidades de Conservação Intenções e Resultados. São Paulo, 1995. 302p. Dissertação (M.S.) - Universidade de Sào Paulo.

CARVAlHO, H.G. Informática e Desempenho. Dois Pontos, V. 2 (14), p.29-31, 1992.

CEBAllos, H. Una nova cultura mediambiental del turismo. Medio Ambiente Tecnologia i Cultura, n. 3, p. 92-95, 1992

CHAVES , E. O. C. Multimídia: Conceituação, Aplicões e Tecnologias, São Paulo: People Computação, 1991. 204p.

CHAVES, E.O.C. \& SETZER, V.W. O uso de computador em escolas, $1^{0}$ ed. São Paulo: Scipione, 1988.

CONSÓRCIO MATA ATLÂNTICA. Reserva da biosfera da Mata Atlântica. Plano de Ação. Campinas, 1991.1v.

DIAS, G.F. Educação Ambiental:Princípios e Práticas, São Paulo: Gaia, 1992. $399 \mathrm{p}$.

DIEGUES, A.C.S. O Mito Moderno da Natureza Intocada, São Paulo: HUCITEC, 1996. 169p. 
DIEGUES, A.C.S.; VIANNA, L.P.; ADAMS, C.; OLIVEIRA, E.R.; SANSON, F.E.G.. Conflitos entre populações humanas e áreas naturais protegidas na Mata Atlântica. São Paulo, Séries: Documentos e Relátorios de Pesquisa. NUPAUB/USP $\mathrm{n}^{\mathrm{O}} 21$. p. 282,1995

DIEGUES, A.C.S., Pescadores, Camponeses e Trabalhadores do Mar (Col. Ensaios/94), São Paulo: Ed. Ática, 1983.

DIMENSTeIM, G. America. Folha de São Paulo, São Paulo, 14 jul. 1996. p.123.

FAGUNDES, L. Informática na Escola, Tecnologia Educacional, Rio de Janeiro,v. 21, p.79-84, jul/ago. 1992.

FOLHA DE SÃo PAULO. Saberes, São Paulo, 17 nov.,1995.

FOLHA DE SÃo PAULO. Favelização avança no Litoral Norte de São Paulo, Cotidiano, São Paulo, 20 out., 1996.

FOLHA DE SÃO PAULO. Litoral fecha porta para turista de 1 dia, Cotidiano, São Paulo, 7 jan., 1997.

FORUM INTERNACIONAL ONGs,. Tratado de Educação Ambiental para Sociedades Sustentáveis e Responsabilidade Global. 1992.

FUNDAÇÃO SEADE. Análise Demografica Regional: Litoral, São Paulo, $1982.42 \mathrm{p}$. 
GIULIETTI , A. M. Biodiversidade da região sudeste. In: II CONGRESSO NACIONAL SOBRE ESSÊNCIAS NATIVAS, São Paulo, 1992. Resumos. São Paulo, v.4, p. 125-30.

GUATURA,I.S.; CORRÊA F.; COSTA J.P.O. AZEVEDO P.U.E.. A Questão Fundiária -Roteiro para Solução dos Problemas das Áreas Protegidas. Reserva da Biosfera, Caderno 1, p.31, 1994.

HERNANDES V. K. O computador com a escola: desafios interdisciplinares. São Paulo. 1996. p 140. Disertação (M.S.) - Pontifícia Universidade Católica.

HERZ R., Manguezais do Brasil, São Paulo: Laboratório de Sensoriamento Remoto, 1991.

HUECK , K. Plantas e formação organogênica de dunas do litoral paulista . Instituto de Botânica ,Parte 1, p.130, 1955.

INSTITUTO SOCIOAMBIENTAL, Povos Indígenas no Brasil 1991/1995, São Paulo: Instituto Socioambiental, 1995.

JOLY,C.A., LEITÃO FILHO, H.F., \& SILVA, S.M. O patrimônio florístico The floristic heritage. In: CÂMARA, G., I. coord. Mata Atlântica - Atlantic Rain Forest. São Paulo: Index Ltda e Fundação S.O.S. Mata Atlântica, 1991. $188 \mathrm{p}$.

KIRIZAWA, M.; LOPES, E. A.; PINTO, M. M.; LAM, M.; LOPES, M. I. M. 
SILVEIRA. Vegetação da Ilha Comprida: Aspecto Fisionômico e Florístico. In: II CONGRESSO NACIONAL SOBRE ESSÊNCIAS NATIVAS, São Paulo, , São Paulo, 1992. Anais. São Paulo: Revista do Instituto Florestal, 1992. v4, p. 339-648.

LADEIRA, M.I. Os Guarani na Mata Atlântica In: INSTITUTO SOCIOAMBIENTAL.Povos Indígenas no Brasil 1991/1995 : Os Guarani na Mata Atlântica. São Paulo: Instituto Socioambiental, 1995. p. 773-780.

LADIM, S.M.M.; SANTOS, L.M.S.C.; ABREU,V.R.C. Informatização da Escola Pública da Estado do Rio de Janeiro, In:VII CONGRESSO INTERNACIONAL LOGO E I CONGRESSO DE INFORMÁTICA EDUCATIVA NO MERCOSUL, Porto Alegre, 1995. p. 336-345.

LAMBERT, A. Contribuição ao conhecimento da ecologia das plantas do manguezal de Itanhaém. São Paulo, Boletim de Botânica,v. 23, n.317, 1969.

LEITÃO FILHO, H.F. Aspecto taxonômico das florestas do Estado de São Paulo. Silvicultura em São Paulo,v. 16A, p. 197-205, 1982.

LITTO, F. M. A educação para o futuro e a tecnologia: uma visão tecnicista e antitecnicista. Dois Pontos, v. 2, n. 16, p. 97-10, 1993.

LUCHIARI, M. T. D. P. Caiçaras, Migrantes e Turistas: A Trajetória da Apropriação da Natureza no Litoral Norte Paulista (São Sebastião - Distrito de Maresias). Campinas, 1992. 206p. Dissertação (M.S.) - Universidade Estadual de Campinas. 
LUEDERWALDT, H. Os Manguezais de Santos. São Paulo, Revista do Museu Paulista, v.11, p.1, 1919.

LUEDERWALDT, H. Resultados de uma excursão científica à Tha de São Sebastião no litoral do Estado de São Paulo. São Paulo, Revista do Museu Paulista, v.16, p.1-79, 1929.

MACIEL, F.B., MERCADO L.P.L. O computador como agente modificador político social nas escolas de Maceió- AL. In: VII CONGRESSO INTERNACIONAL LOGO E I CONGRESSO DE INFORMÁTICA EDUCATIVA NO MERCOSUL, Porto Alegre, 1995. Anais. Porto Alegre, 1995. p. 317-323.

MACHADO, L.M.C.P.. A Serra do Mar Paulista: Um Estudo de Paisagem Valorizada. Rio Claro, 1988. Tese (Doutorado) - Universidade Estadual Paulista.

MACHADO, N.J. Informática na Escola: significado do computador no processo educacional. Acesso, ano 4, p.28-36, dez 1993.

McCREA E.J.\& GREENBERG L.S.Z. Directorio de Materiales Selectos de Educacion Ambiental. New York: WRI, 1988. 75p.

MILANO, M.S. Sistema Nacional de Unidades de Conservação Brasil: a realidade técnico-político. IN: CONGRESSO FLORESTAL BRASILEIRO, 6, Campos do Jordão/SP. SBS-sbef. V1, 1990. p. 134-138. 
MARTIN, J. Hiperdocumentos e como criá-los, Rio de Janeiro: Campus, 1992.

NOGUEIRA, L. O computador na escola: mesa-redonda. In:VII CONGRESSO INTERNACIONAL LOGO E I CONGRESSO DE INFORMÁTICA EDUCATIVA NO MERCOSUL, Porto Alegre, 1995. Anais. Porto Alegre, 1995. p. 346-353

PHILLIPS, O. L.; GENTRY, A. H. Increasing turnover through time in tropical forest. Science, n. 263, p. 954-958, 1994.

RIZZINI, C. T. Tratado de Fitogeografia do Brasil: Aspecto Ecológicos, São Paulo: HUCITEC / EDUSP, v. 1. 1976.

RIZZINI, C. T. Ecossistemas Brasileiros / Brazilian Ecosystems, Rio Janeiro: Index, $1988.200 \mathrm{p}$.

RIZZINI, C. T. Nota prévia sobre a divisão fitogeográfica (florística-sociológica) do Brasil. Revista Brasileira de Geografia, v.1, n.25, p. 3-64. 1963.

ROMARIZ, D.A.. A Vegetação.. In: Azevedo, A. (coord.). Brasil a terra e o homem. São Paulo: Nacional, 1972. v.1. p: 521-562.

ROGERS, C. R. Liberdade para aprender em nossa década. Artes Médicas, trad. de José Octavio de Aguiar Abreu, 1985.

SÃO PAULO (Estado). Secretaria do Meio Ambiente, Coordenadoria de 
Informações Técnicas, Documentos e Pesquisa Ambiental, Instituto Florestal. Inventário Florestal do Estado de São Paulo. São Paulo, 1993. 199p.

SEADE, FUNDAÇÃO SISTEMA ESTADUAL DE ANÁLISE DE DADOS. Perfil Municipal do Estado de São Paulo (software), São Paulo, 1995. 4 disquetes.

SECRetaria do MEIO AMBIENTE Mapa das Áreas Naturais Protegidas do Estado de São Paulo, São Paulo, 1989.

SENNA, L.A.G., 1995. Softwares Educacionais: um desafio conceitual para a ciência lingüistica In:VII CONGRESSO INTERNACIONAL LOGO E I CONGRESSO DE INFORMÁTICA EDUCATIVA NO MERCOSUL, Porto Alegre, 1995. Anais. Porto Alegre, 1995. p. 471-479.

SOS MATA ATLÂNTICA \& INPE. Atlas da evolução dos remanescentes florestais e ecossistemas associados ao domínio da Mata Atlântica no período de 1985-90. São Paulo, 1992/93. Fundação SOS Mata Atlântica.

SIQUEIRA, P. Os Caiçaras e a Rio/Santos, São Paulo em Perspectiva, v.4 , n.3, p. 62-64, out./dez. 1989.

SIQUEIRA, M. F. Análise Florística e Ordenação de Espécies Arbóreas da Mata Atlântica Através de Dados Binários. Campinas, 1994. 143p. Dissertação (M.S.) - Universidade Estadual de Campinas.

SILVA, A. F. \& LEITÃO FILHO, H. F. Composição florística e estrutura de um 
trecho da mata atlântica de encosta do Município de Ubatuba (São Paulo , Brasil). Revista Brasileira de Botânica, v.5, p. 43-52, 1982.

SILVA,A.C. da. O litoral Norte do Estado de São Paulo, São Paulo: Ed. da USP, 1975.

TRAJBER R. \& MANZOCHI L. H. Avaliando a Educação Ambiental no Brasil: Materiais Inpressos. São Paulo: Gaia, 1996. 225p.

UHL, C.; CLARK, K.; MAQUIRINO, P. Vegetation dynamics Amazonian treefall gaps. NY. Ecology, v.3, n.69, p. 751-763, 1988.

UNESCO. La Educación Ambiental: Las grandes orientaciones de la Conferencia de Tbilisi, Tbilisi, 1972,.55 p.

VALENTE, J. A. Computadores e Conhecimento: Repensando a Educação, Campinas: Gráfica Central da UNICAMP,1993. 409p.

VAUGHAN, T. Multimedia: Making it Work. California. USA. Osborne McGraw -Hill, 1994. 560p.

VÁZQUEZ-YANEZ, C.; OROZCO-SEGOVIA, A. Fisiologia ecologica de semillas en la Estacion de Biologia Tropical "Los Tuxtlas, Veracruz, Mexico". Revista Biologia Tropical. v.1, n.35, p. 85-89. 1987.

VENTURA, V. J. Legislação federal sobre o meio ambiente. Taubaté: Vana Ltda., $2^{0}$ ed. 1148p. 1996. 
VIEIRA,V.L.; MIRABELLI, H., Programa de Educação Ambiental no Vale do Ribeira: A Ocupação e o Povoamento do Vale do Ribeira, Secretaria do Meio Ambiente, São Paulo, v. 2,. 1989. 


\section{ANEXO A}

\section{PRINCÍPIOS DE EDUCAÇÃO AMBIENTAL PARA SOCIEDADES SUSTENTÁVEIS E RESPONSABILIDADE GLOBAL}


1- A educação é um direito de todos: somos todos aprendizes e educadores.

2- A educação ambiental deve ter como base o pensamento crítico e inovador, em seus modos formal (sala de aula), não formal (atividades ao ar livre) e informal (cotidiano), promovendo a transformação e a construção da sociedade.

3- A educação ambiental é individual e coletiva. Tem o propósito de formar cidadãos com consciência local e planetária, que respeitem a autodeterminação dos povos e a soberania das nações.

4- A educação ambiental não é neutra, mas ideológica. É um ato político, baseado em valores para transformação social.

5- A educação ambiental deve envolver uma perspectiva holística, enfocando a relação entre o ser humano, a natureza e o universo de forma interdisciplinar.

6- A educação ambiental deve estimular a solidariedade, a igualdade e o respeito aos direitos humanos, valendo-se de estratégias entre as culturas.

7- A educação ambiental deve tratar as questões globais críticas, suas causas e interrelações em uma perspectiva sistêmica, em seu contexto social e histórico.

8- A educação ambiental deve tratar aspectos primordiais relacionados ao desenvolvimento e ao meio ambiente tais como população, saúde, paz, direitos humanos, democracia, fome, degradação da flora.

9- A educação deve facilitar a cooperação mútua e eqüitativa nos processos de decisão, em todos os níveis e etapas.

10- A educação ambiental deve recuperar, reconhecer, respeitar, refletir e utilizar a história indígena e culturas locais, assim como promover a diversidade cultural, lingüística e ecológica. Isto implica em uma revisão da história dos povos nativos para modificar os enfoques etnocêntricos, além de estimular a educação bilingüe. 11- A educação ambiental deve estimular e potencializar o poder das diversas populações, promover oportunidades para as mudanças democráticas de base que estimulem os setores populares da sociedade. Isto implica a condução de seus 
próprios destinos.

12- A educação ambiental valoriza as diferentes formas de conhecimento. Este é diversificado, acumulado e produzido socialmente, não devendo ser patenteado ou monopolizado.

13- A educação ambiental deve ser planejada para capacitar as pessoas a trabalharem conflitos de maneira justa e humana.

14- A educação ambiental deve promover a cooperação e o diálogo entre indivíduos e instituições, com a finalidade de criar novos modos de vida, baseados em atender às necessidades básicas de todos, sem distinções étnicas, físicas, de gênero, idade, religião, classe ou mentais.

15- A educação ambiental requer a democratização dos meios de comunicação de massa de todos os setores da sociedade. A comunicação é um direito inalienável e os meios de comunicação de massa devem ser transformados em um canal privilegiado de educação, não somente disseminando informações em bases igualitárias, mas também promovendo intercâmbio de experiências, métodos e valores.

16- A educação ambiental deve integrar conhecimentos, aptidões, valores, atitudes e ações. Deve converter cada oportunidade em experiências educativas de sociedades sustentáveis.

17- A educação ambiental deve ajudar a desenvolver uma consciência ética sobre todas as formas de vida com as quais compartilhamos este planeta, respeitar seus ciclos vitais e impor limites à exploração dessas formas de vida pelos seres humanos. 


\section{ANEXO B}

\section{PROTÓTIPO DO CD-ROM, IMPRESSO}




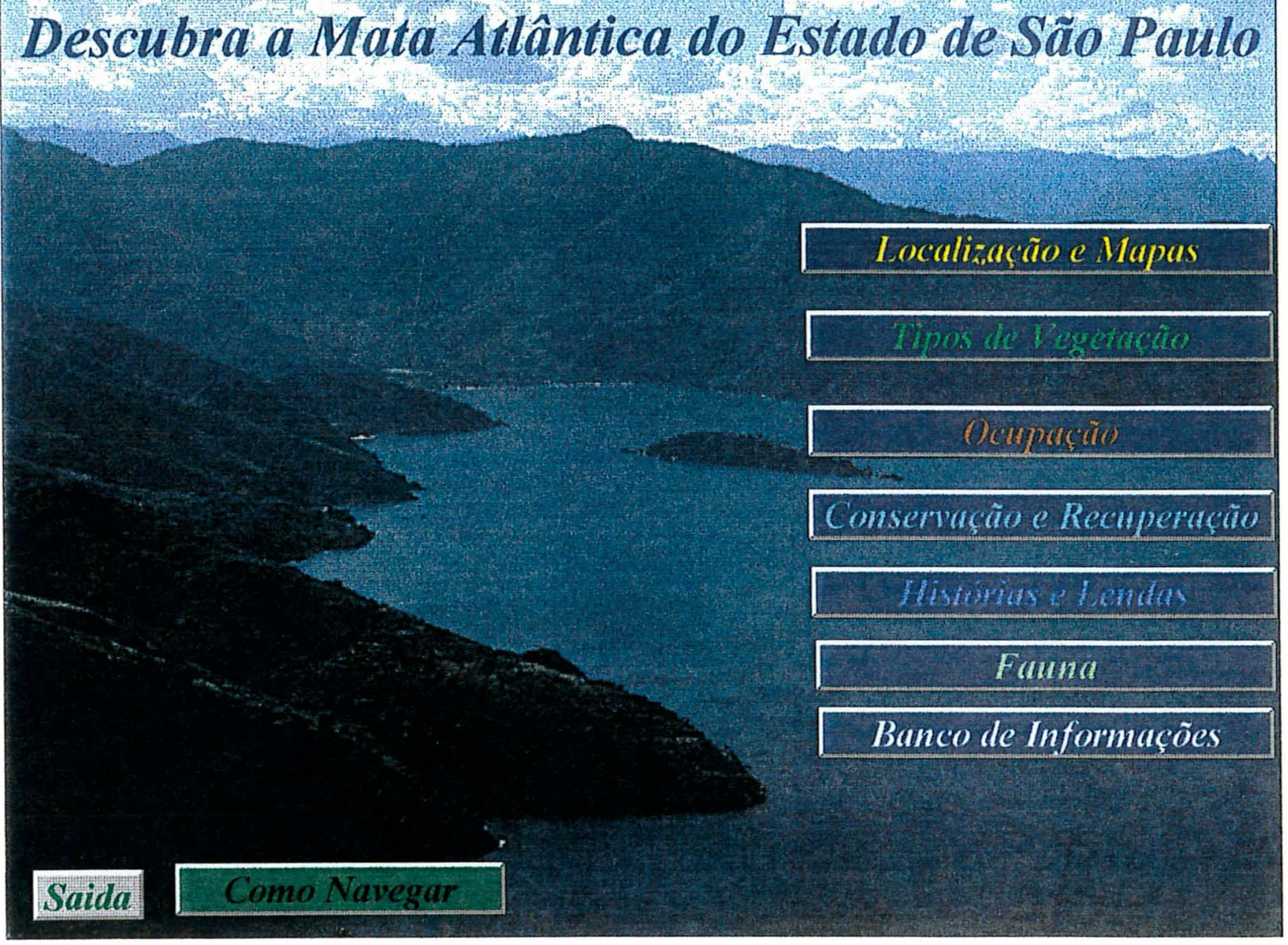




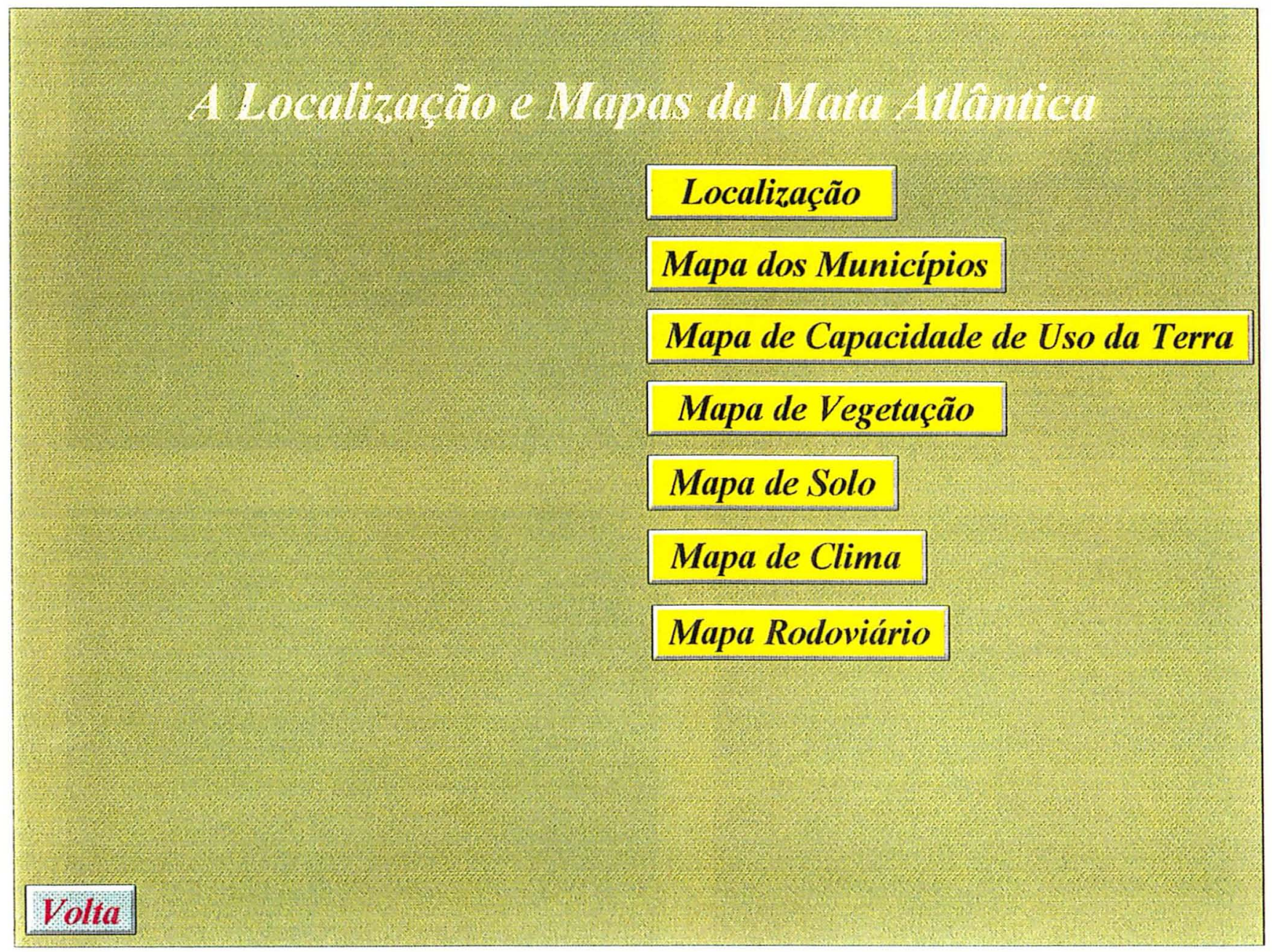



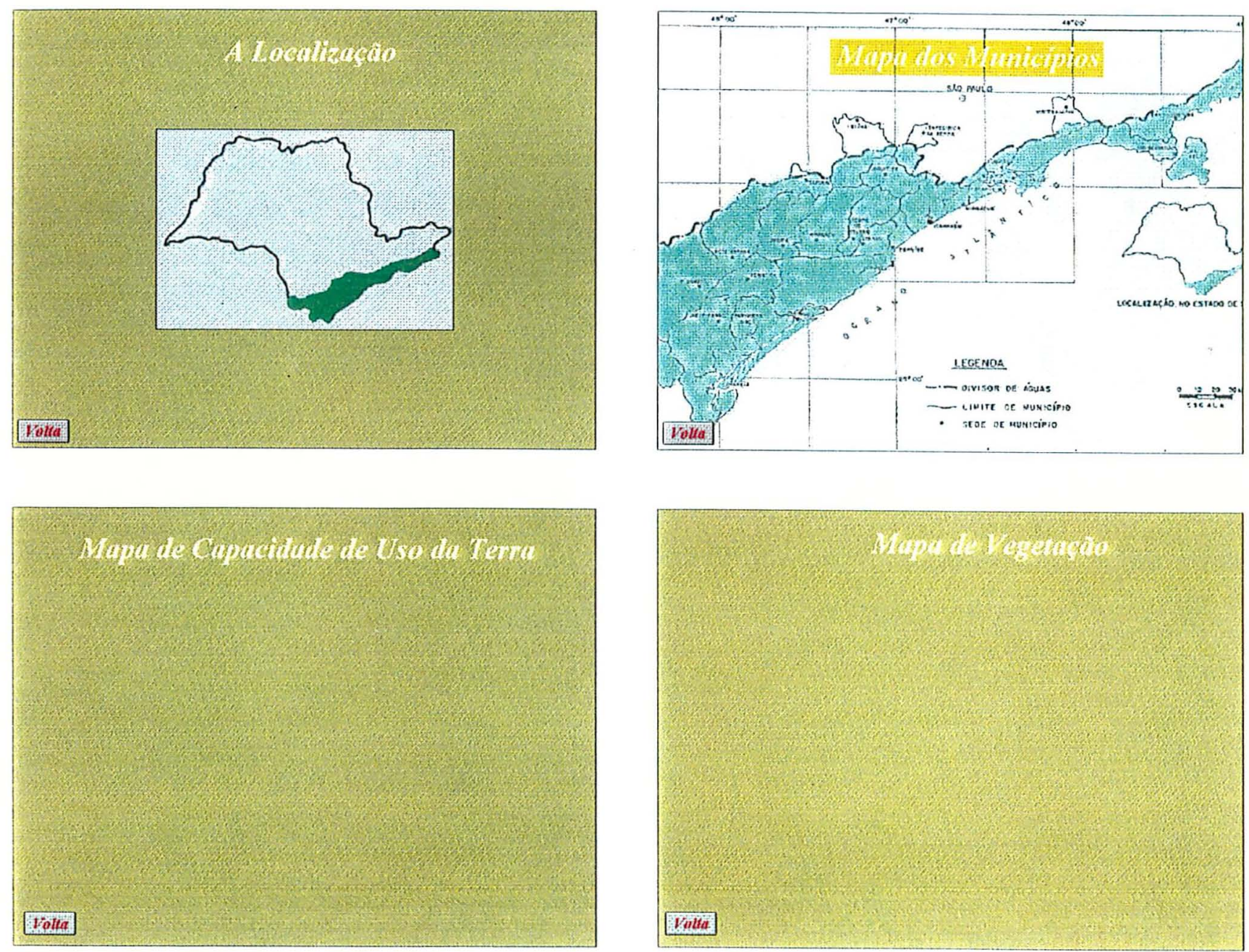

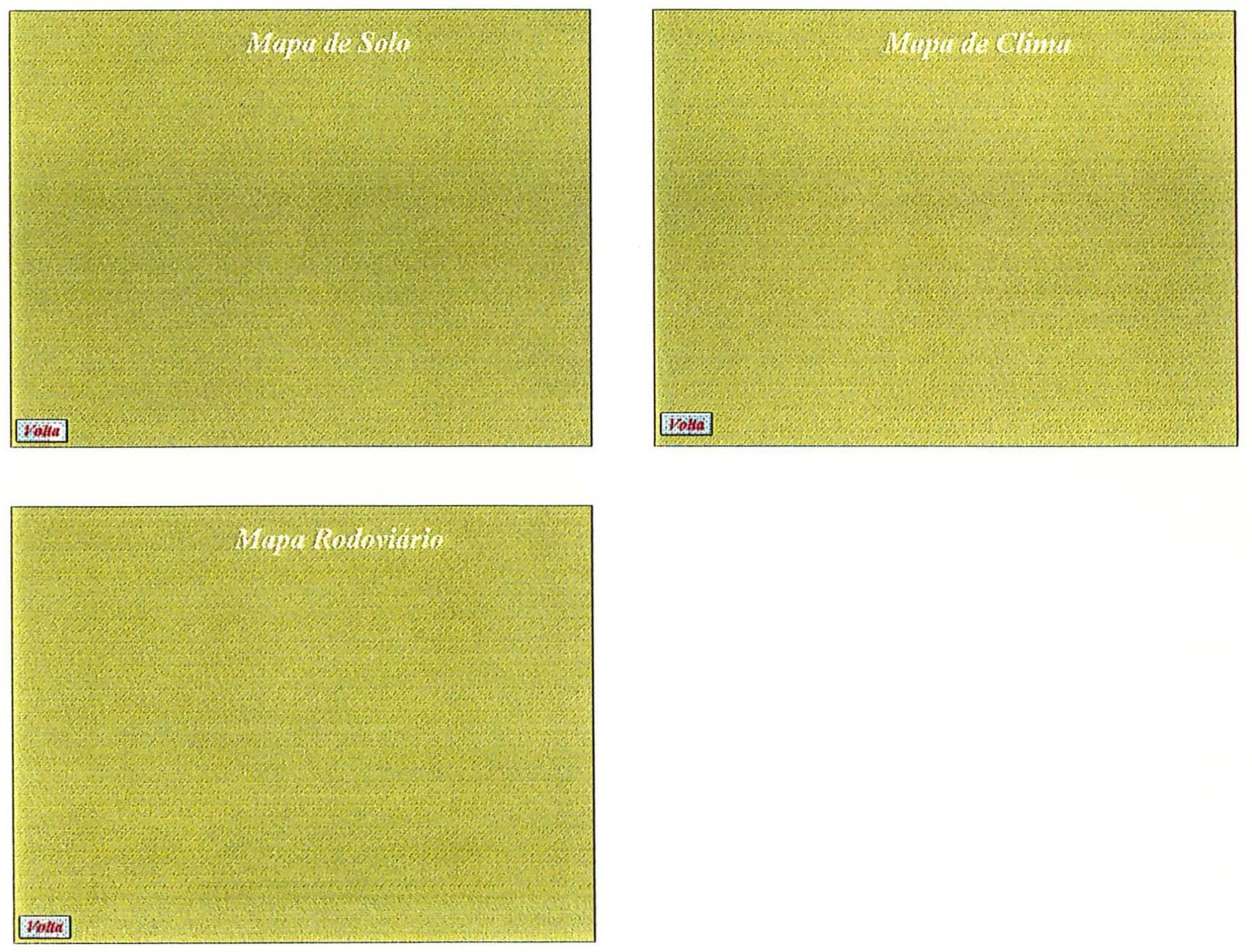
A vegetação da Mata Atlântica do Estado de São Paulo

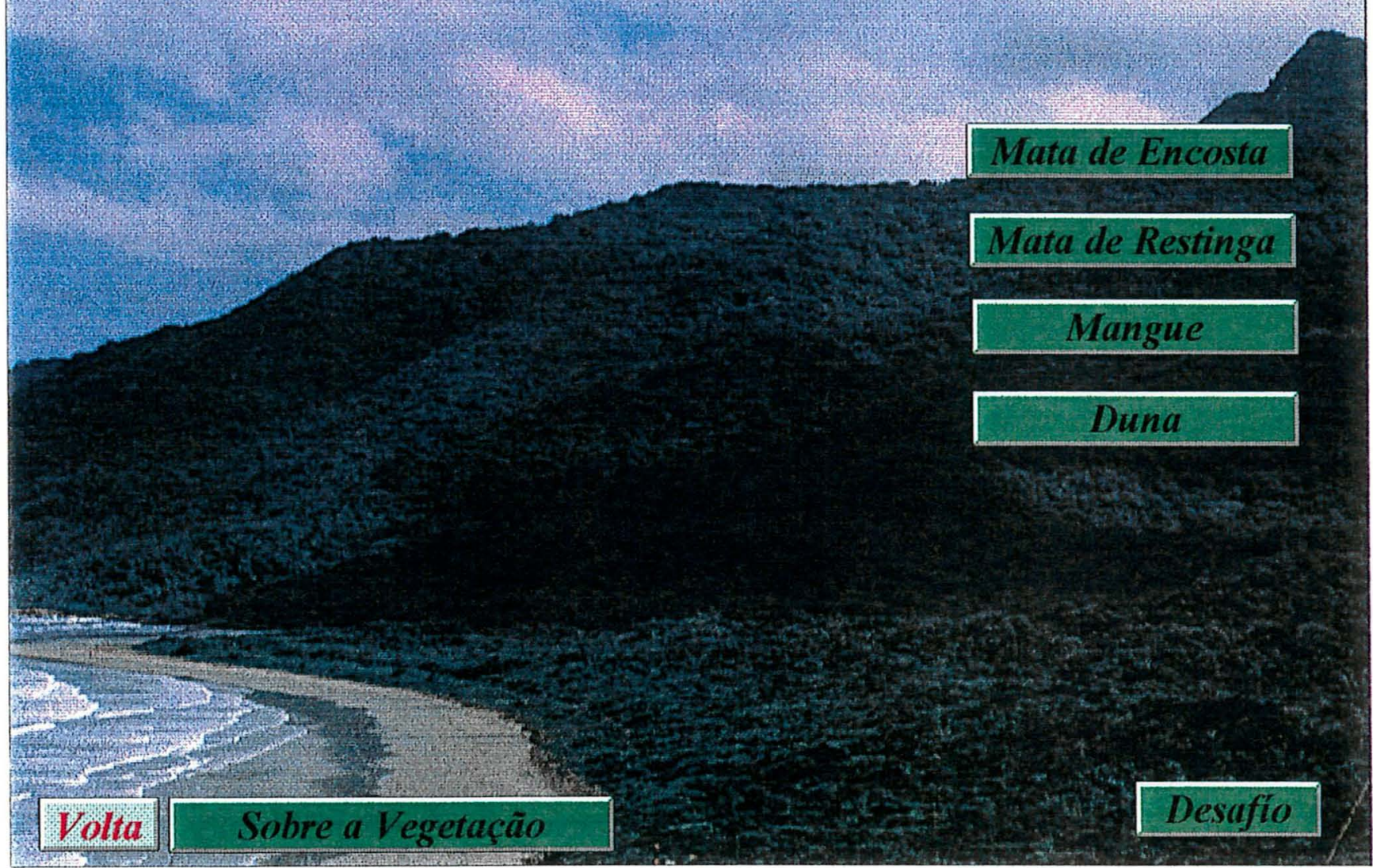




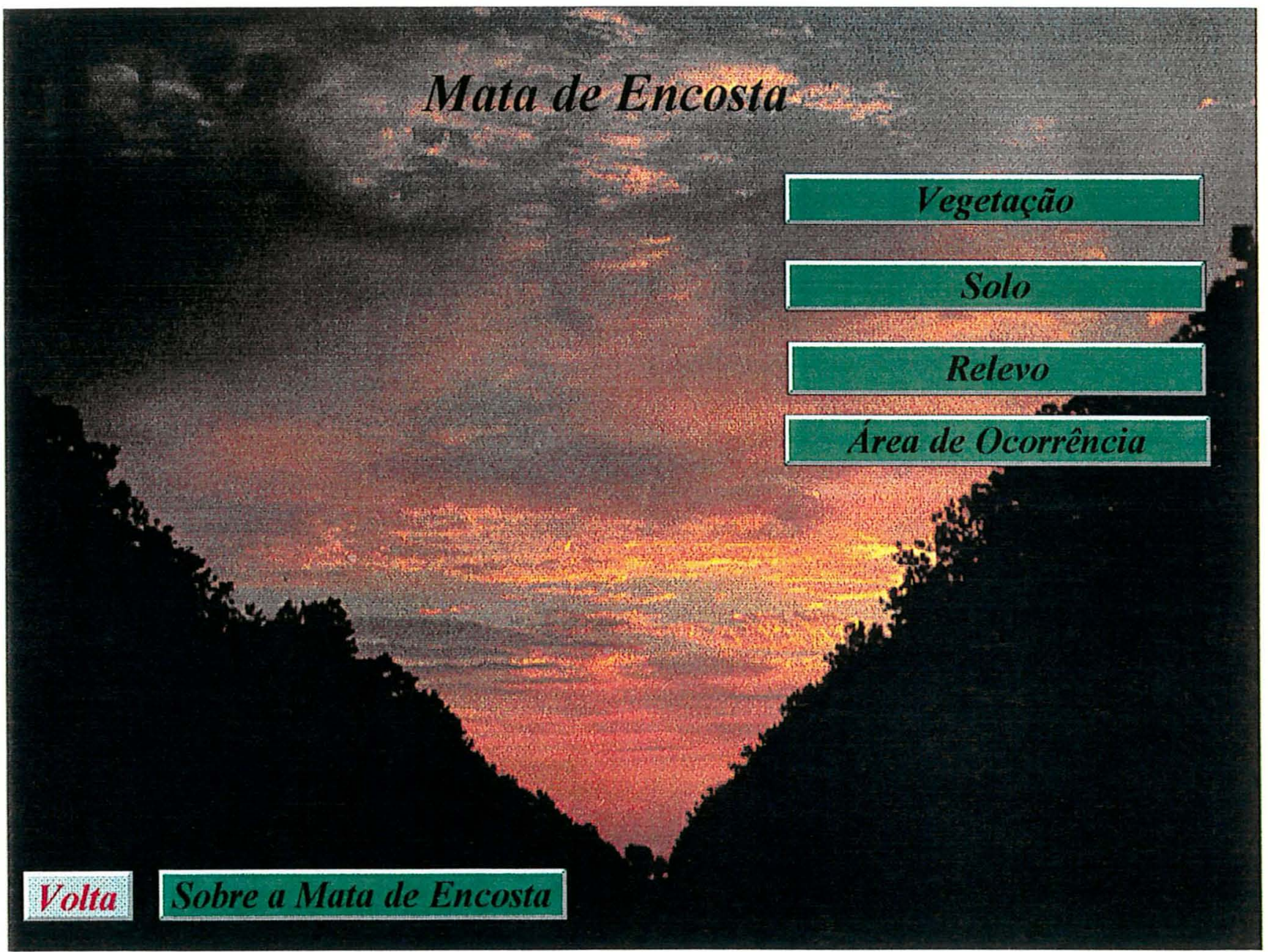



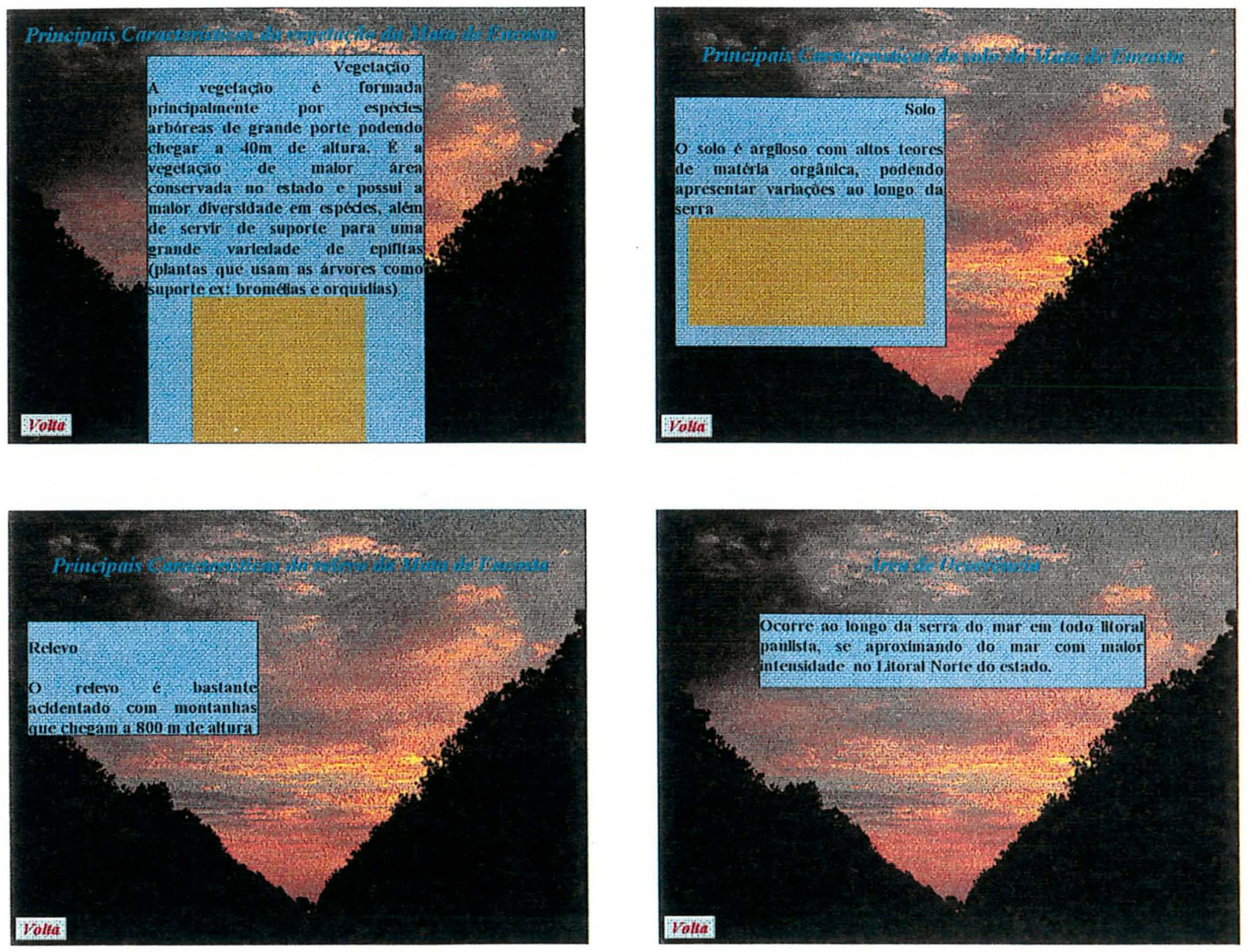


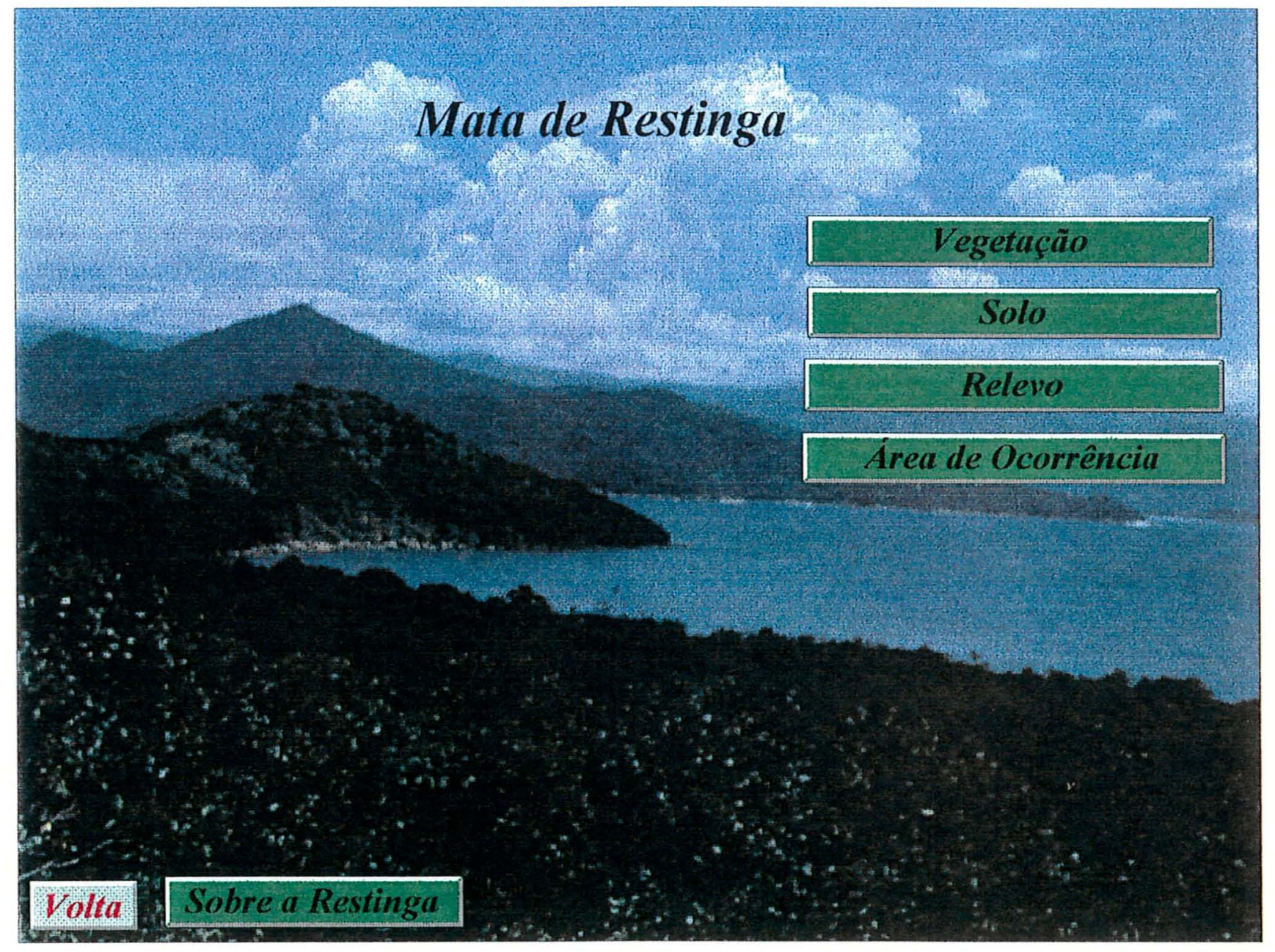



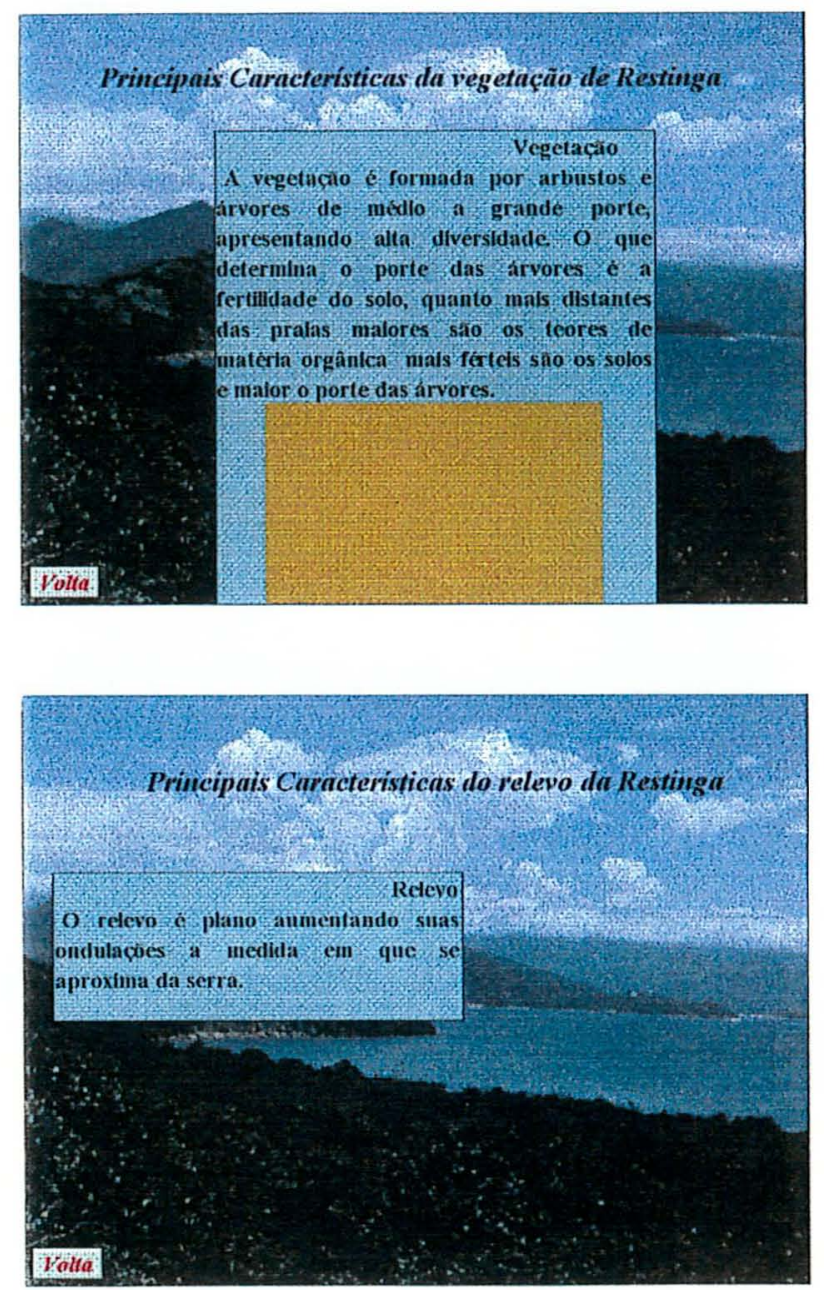
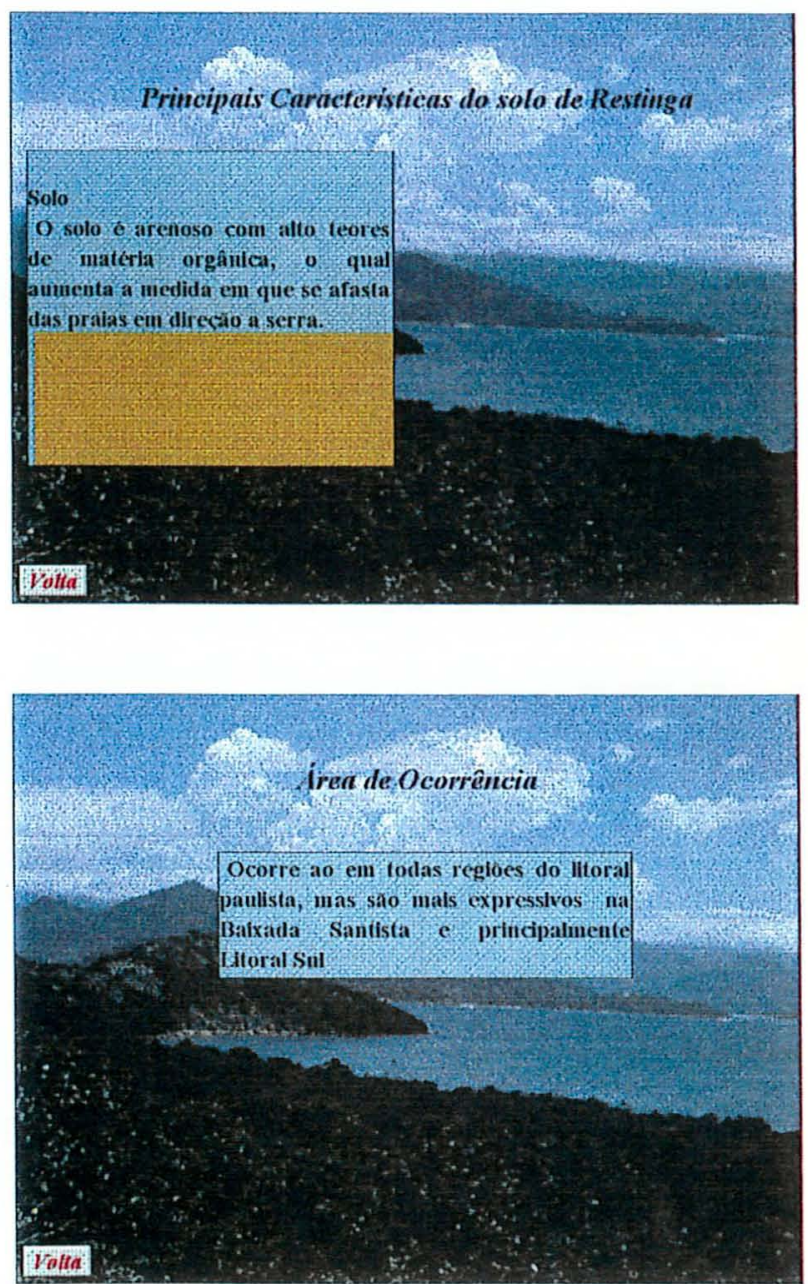


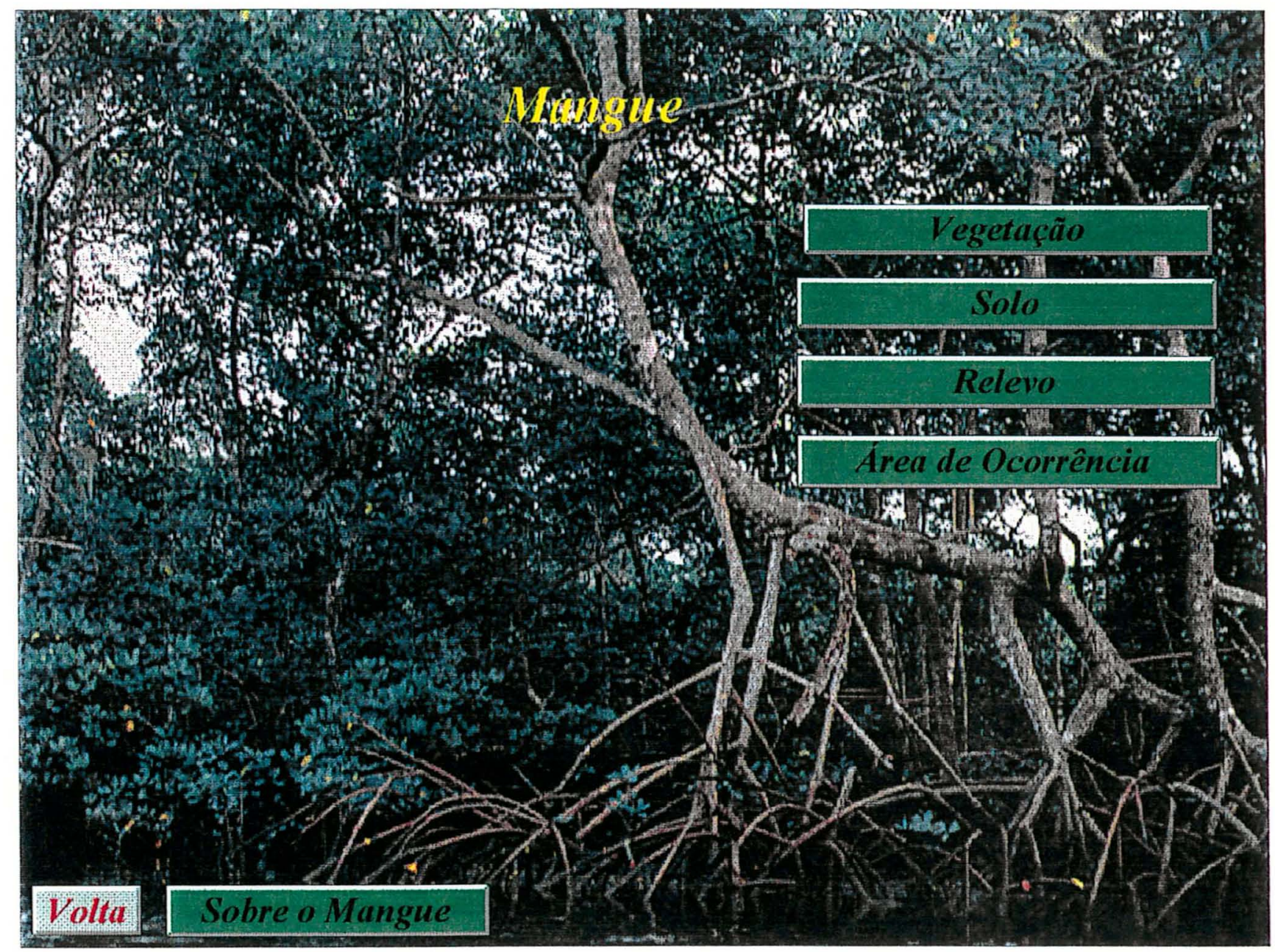



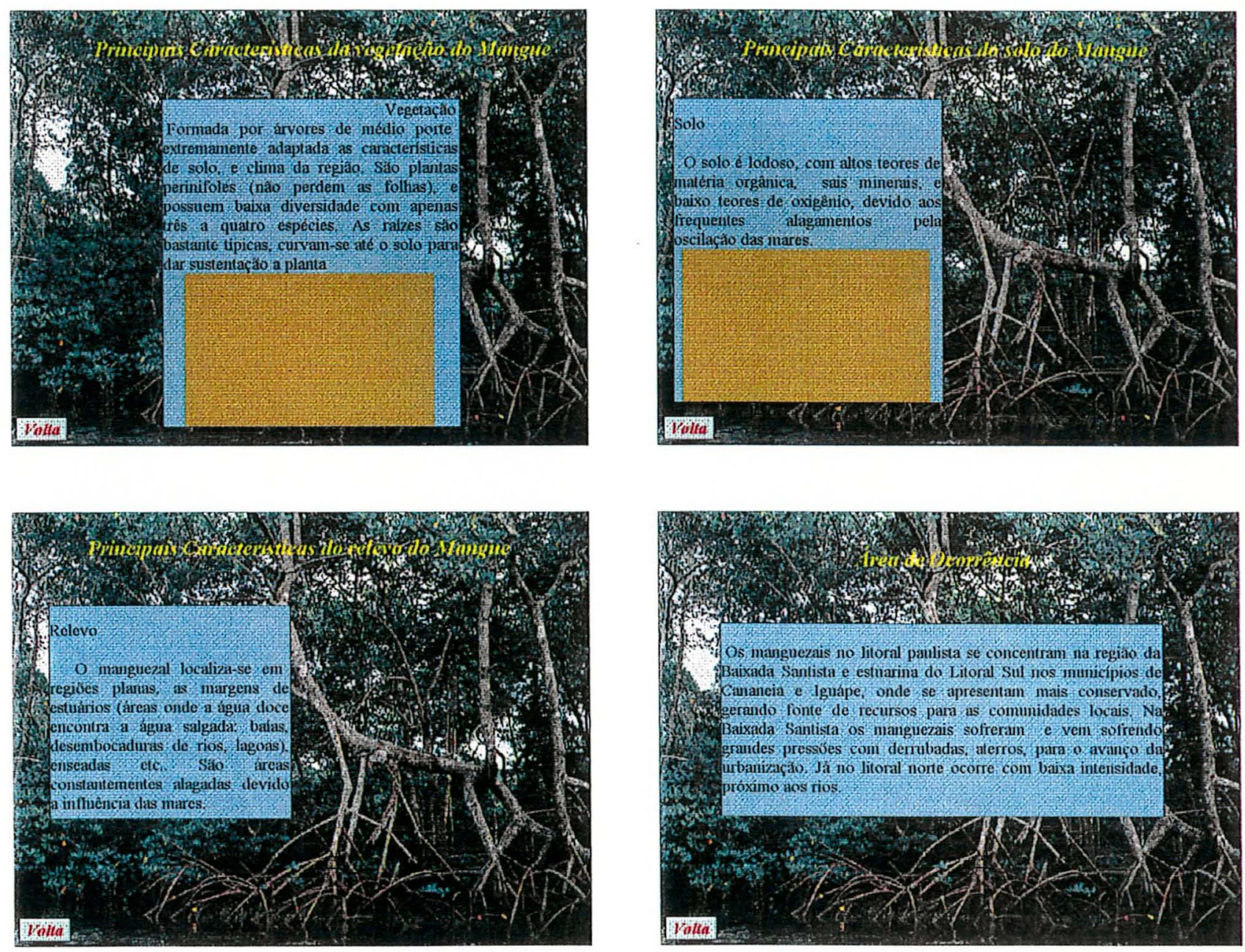


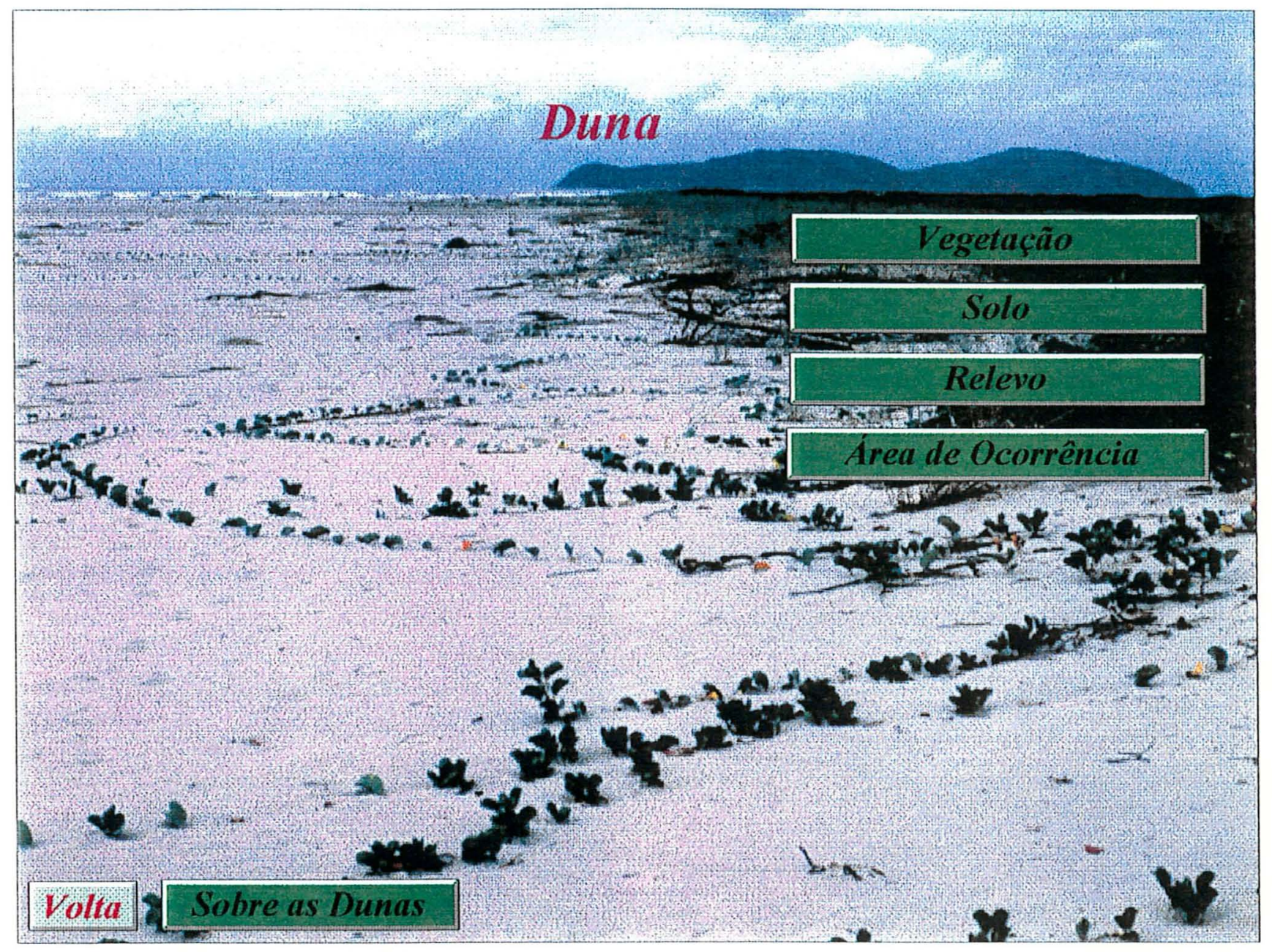



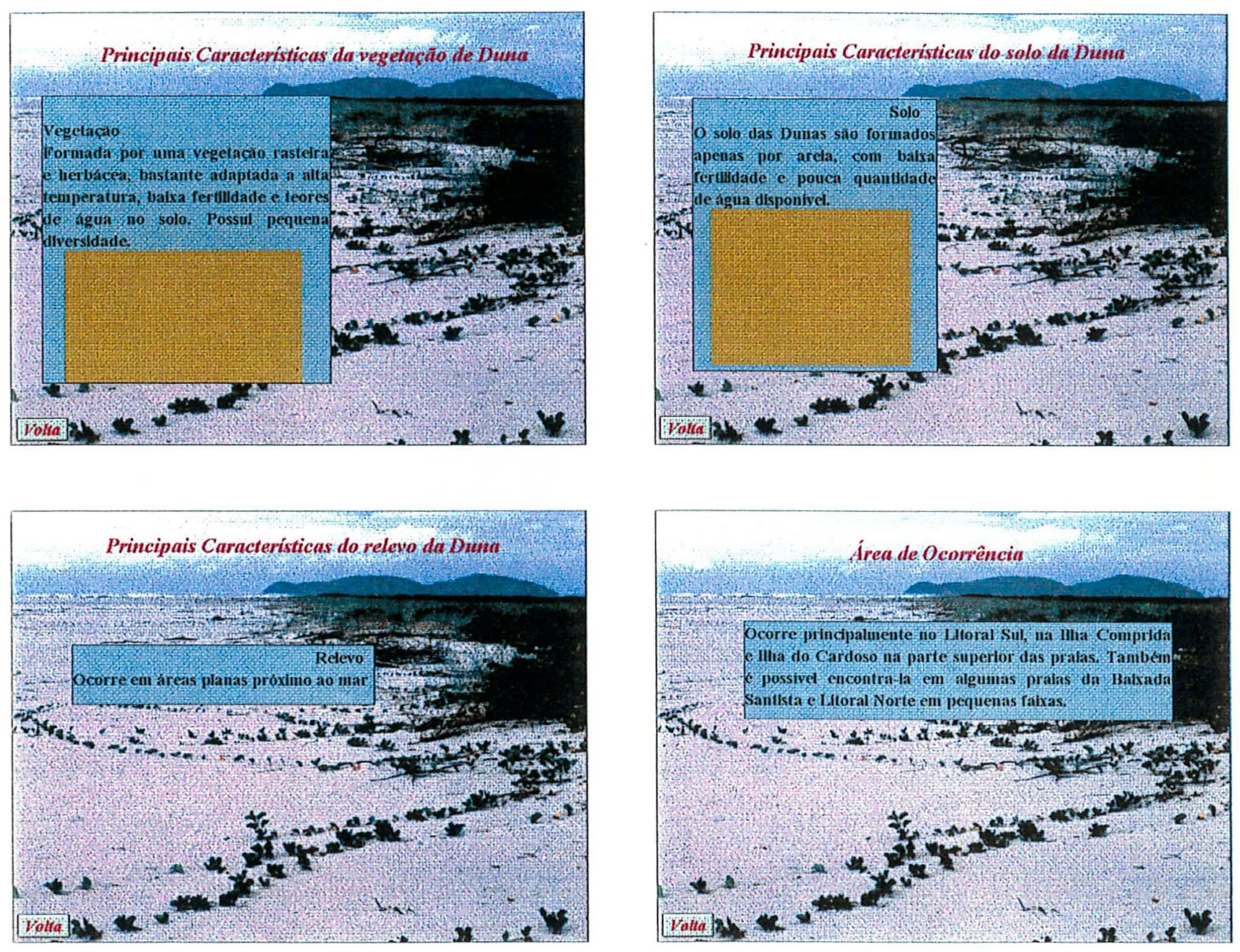


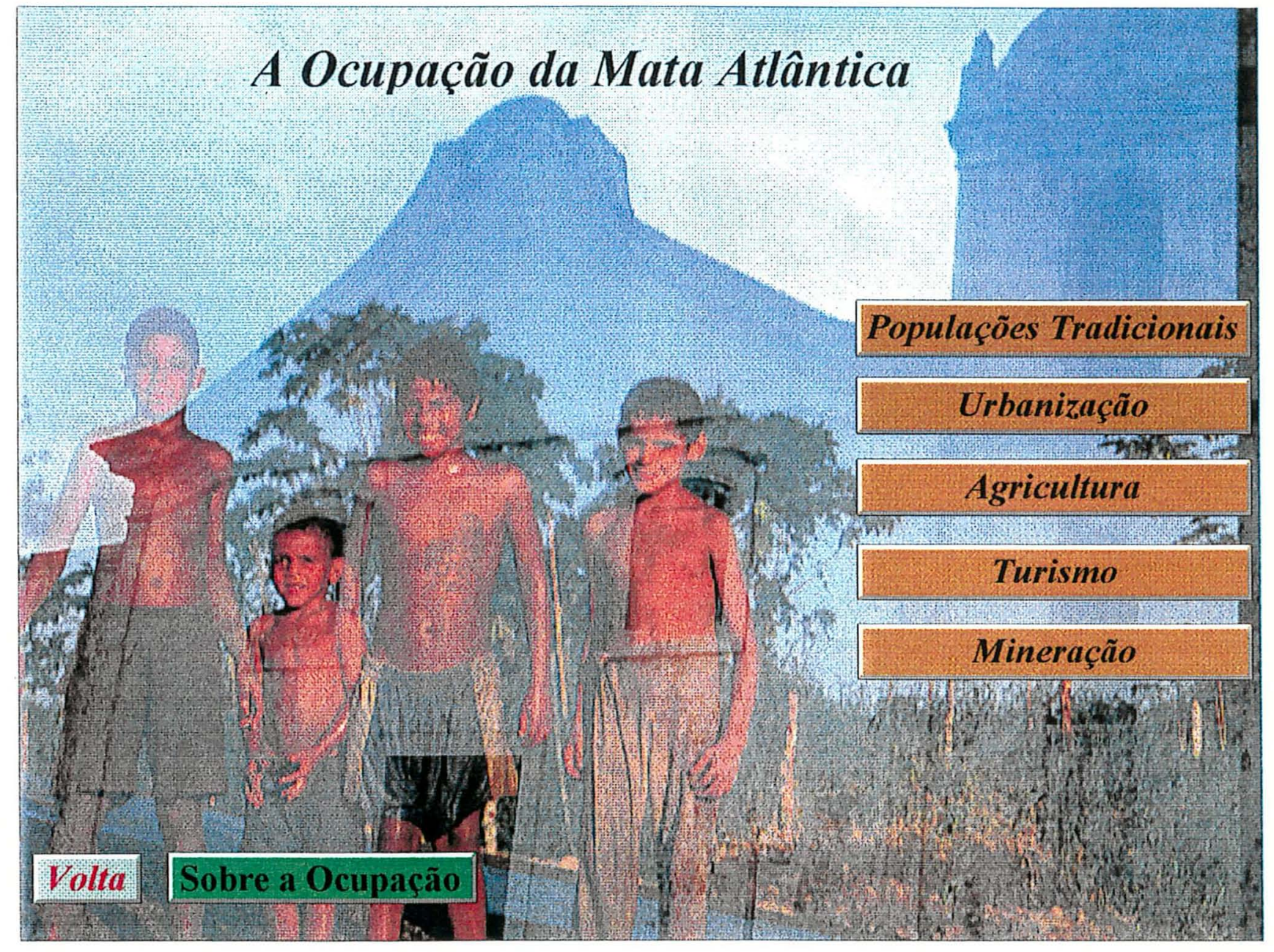



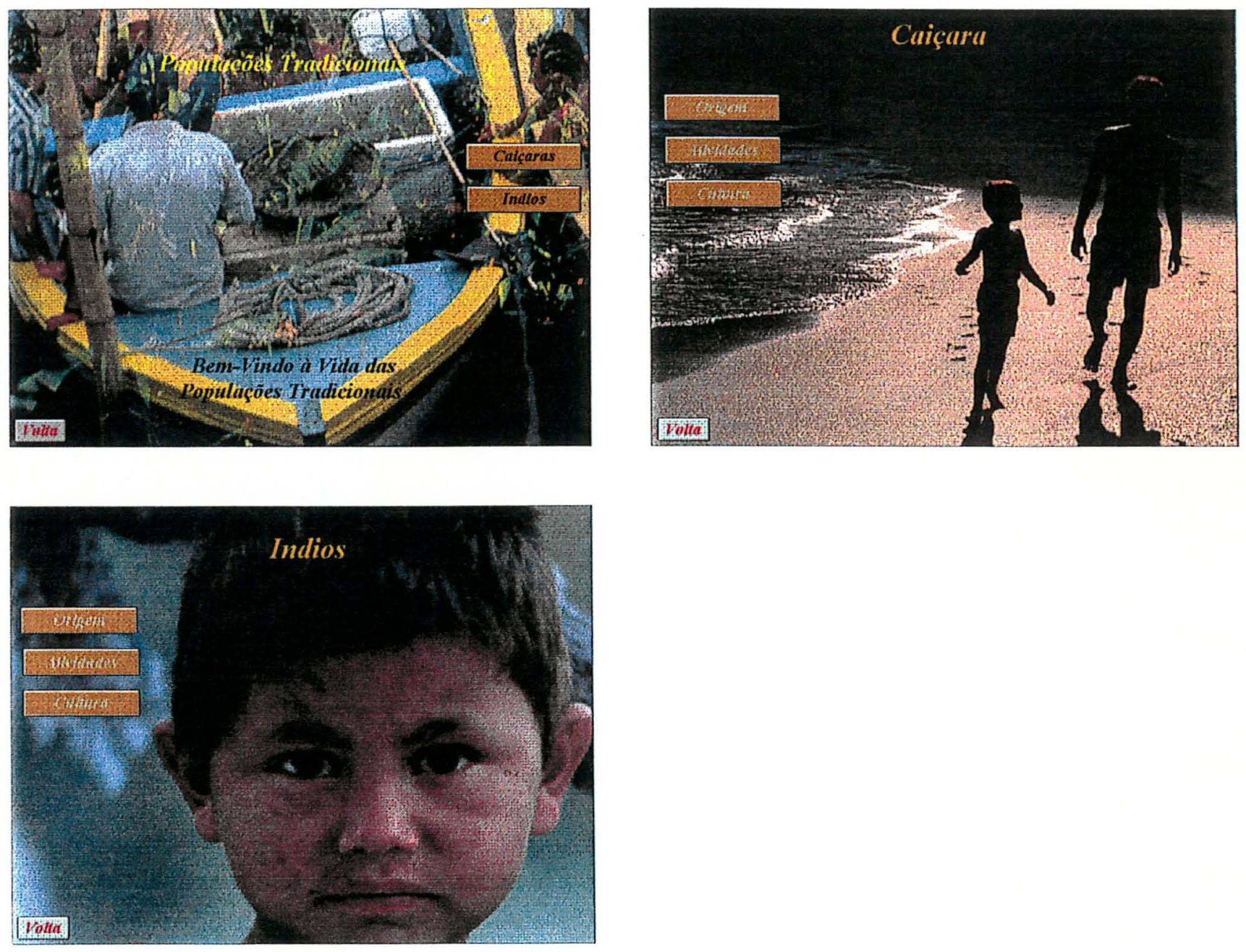

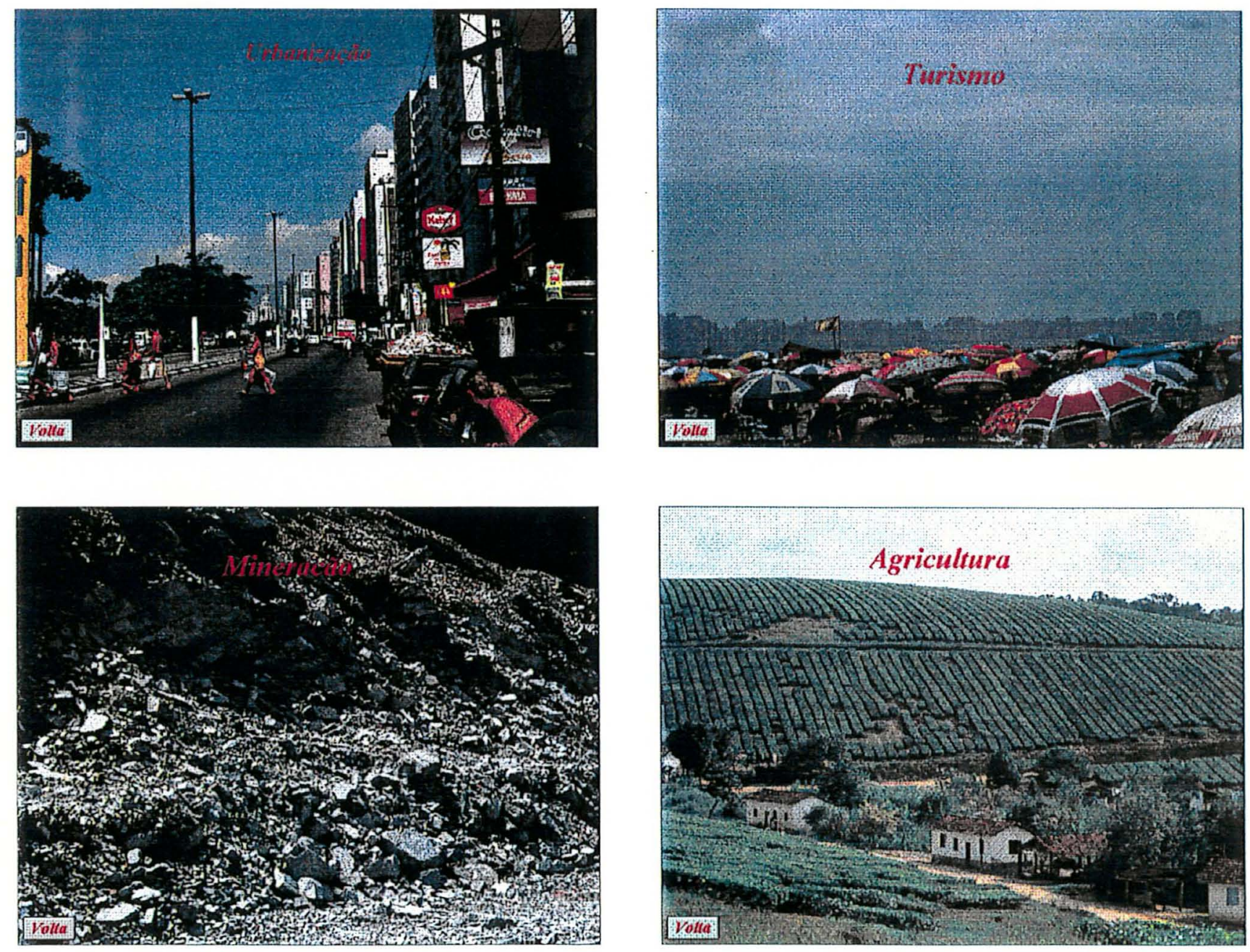


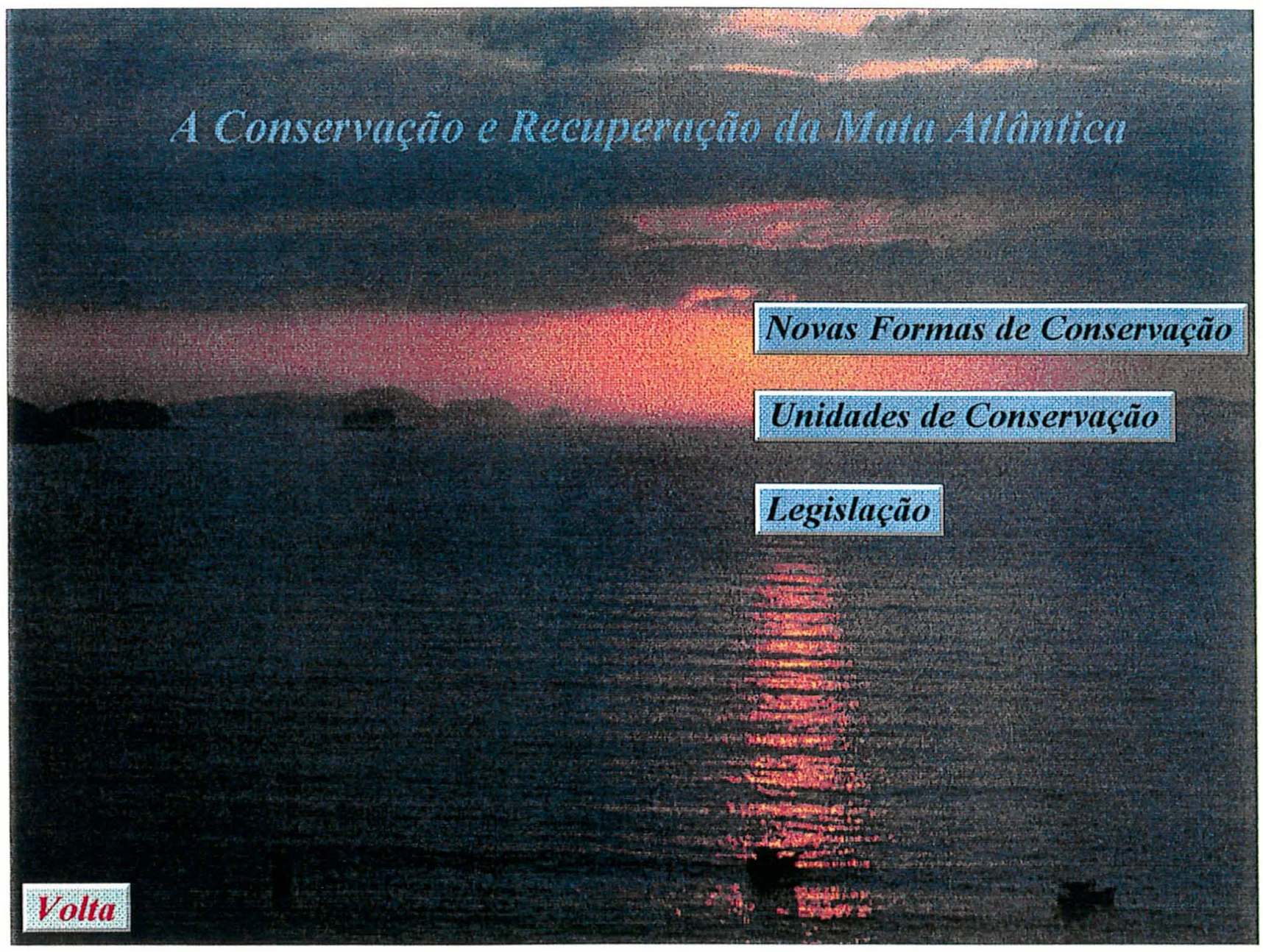



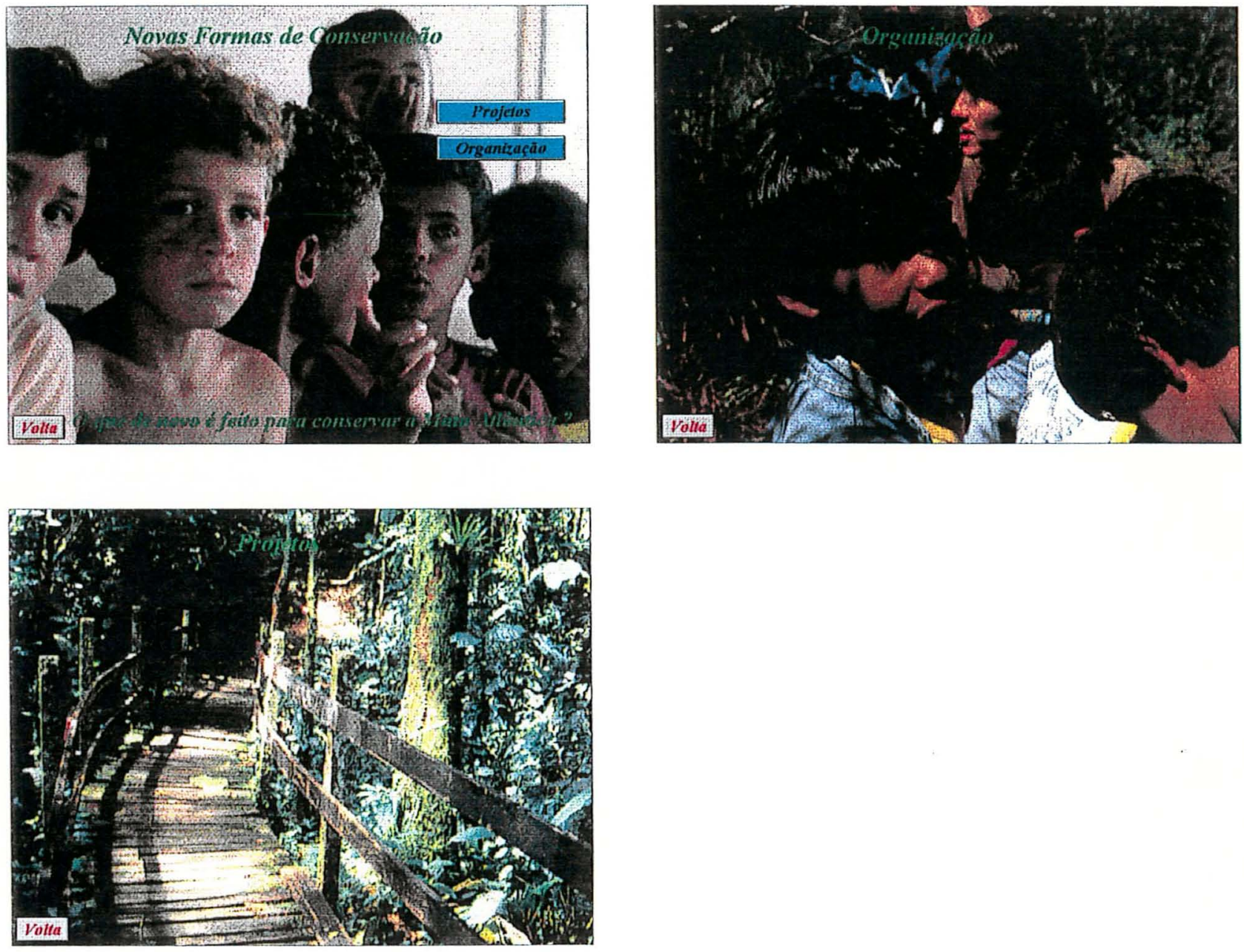

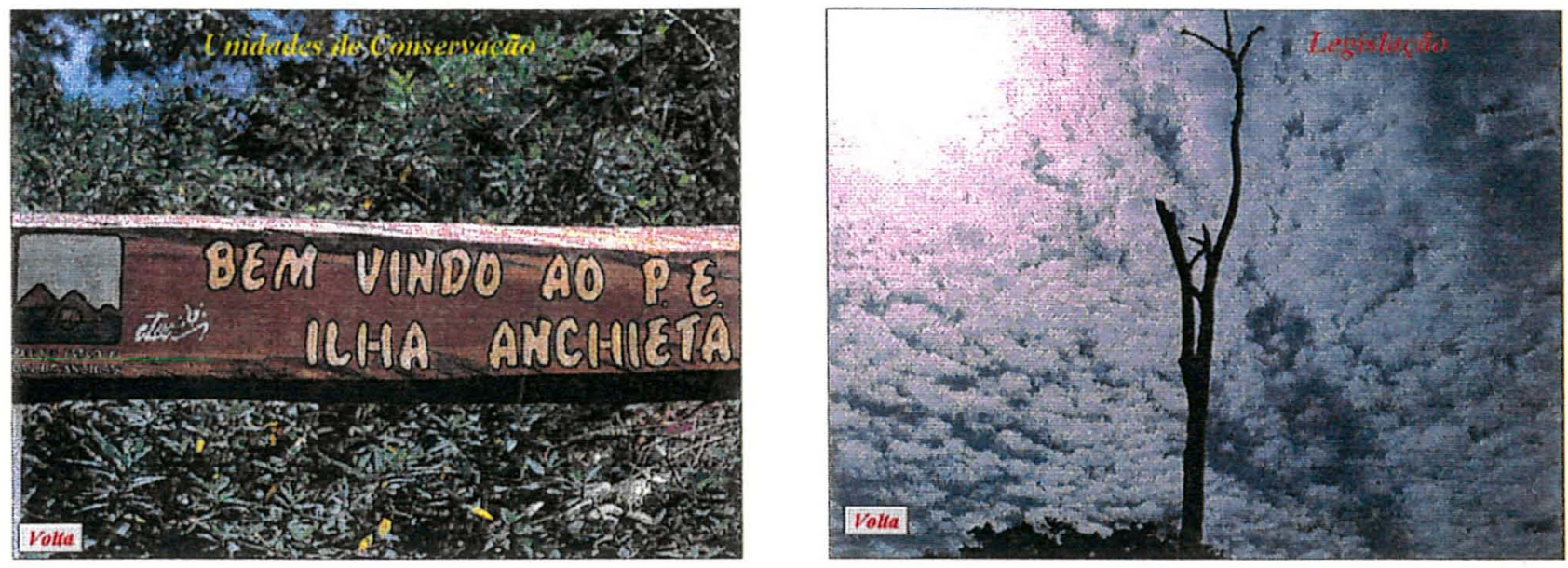


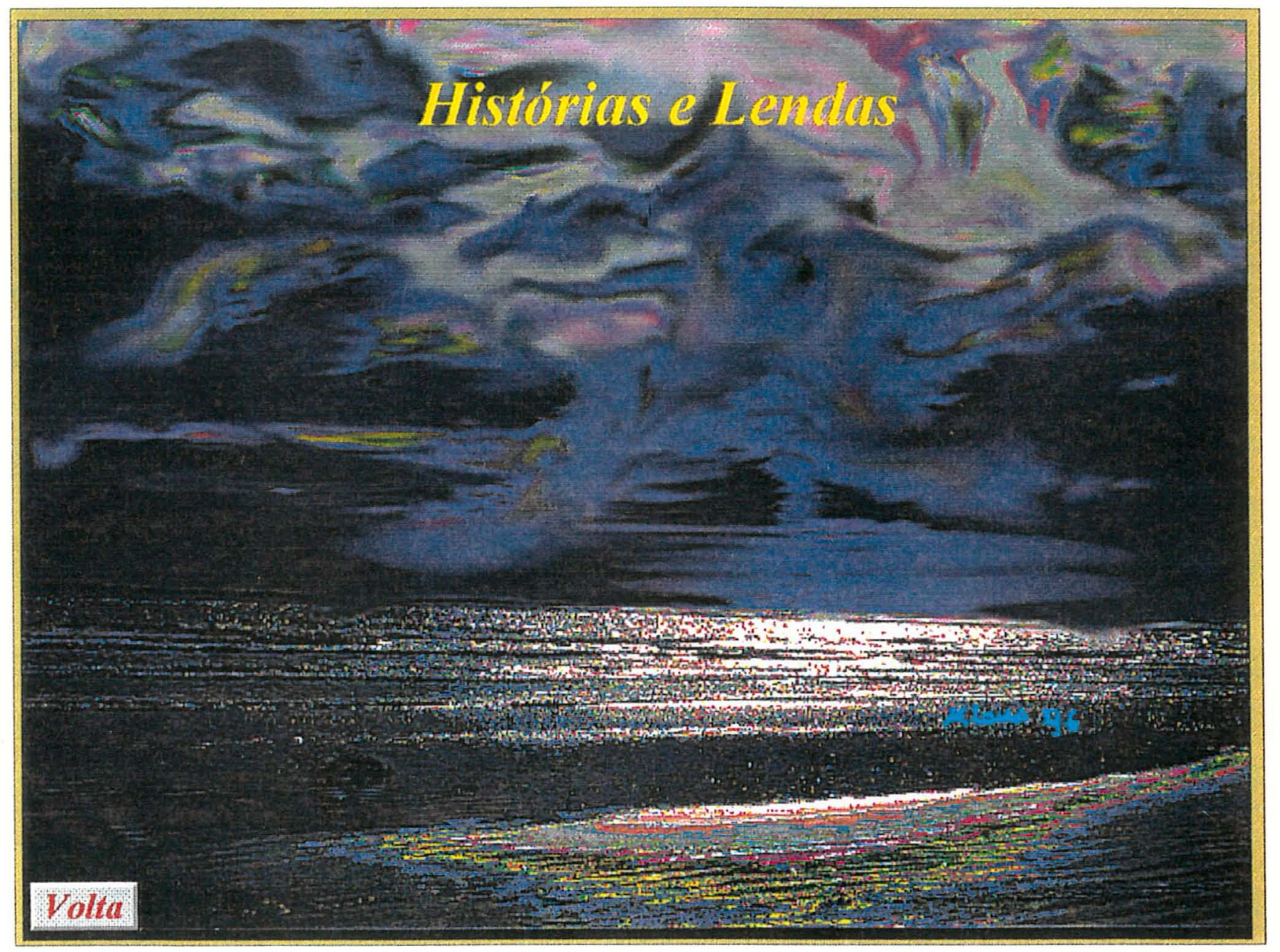




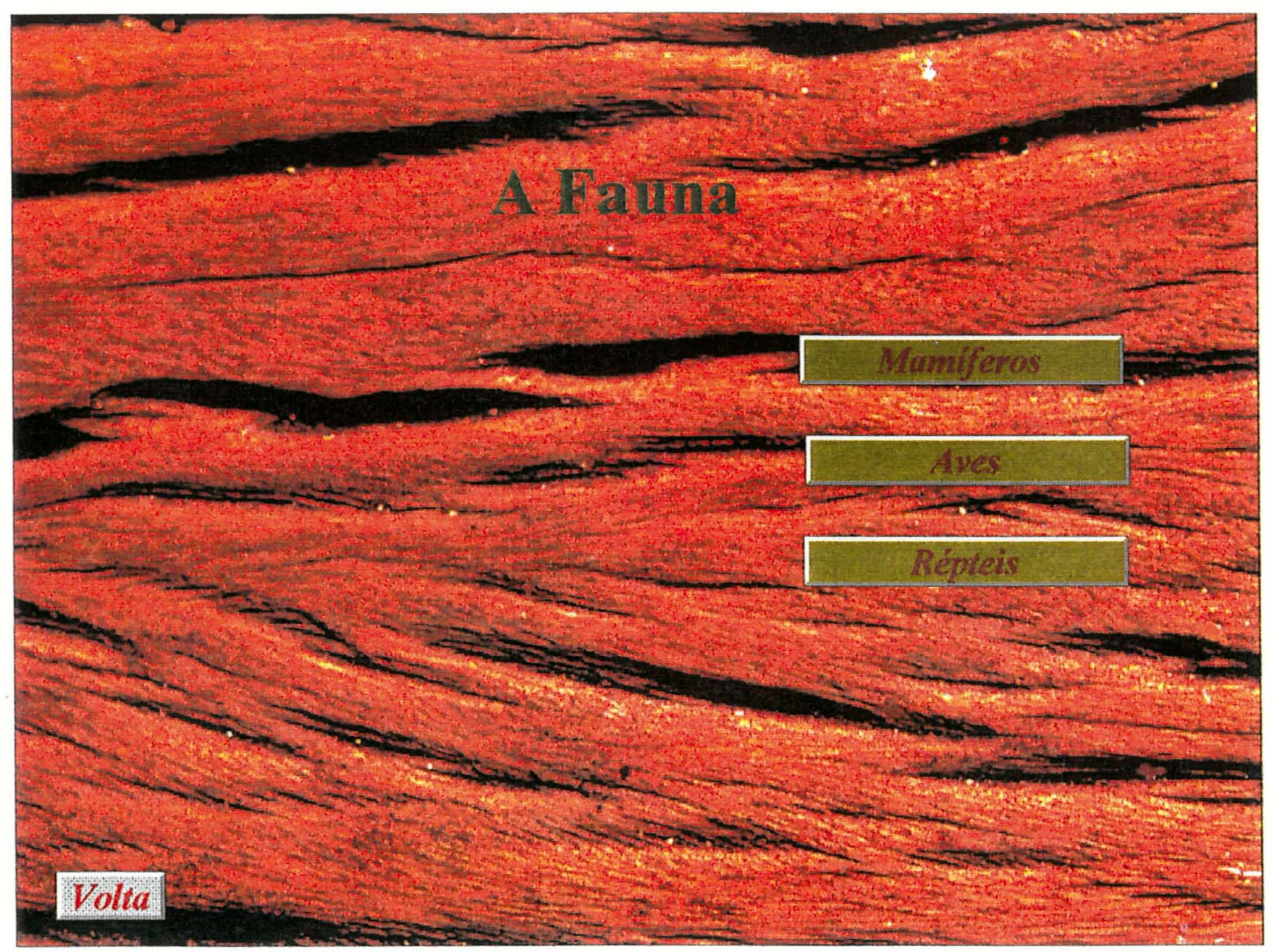



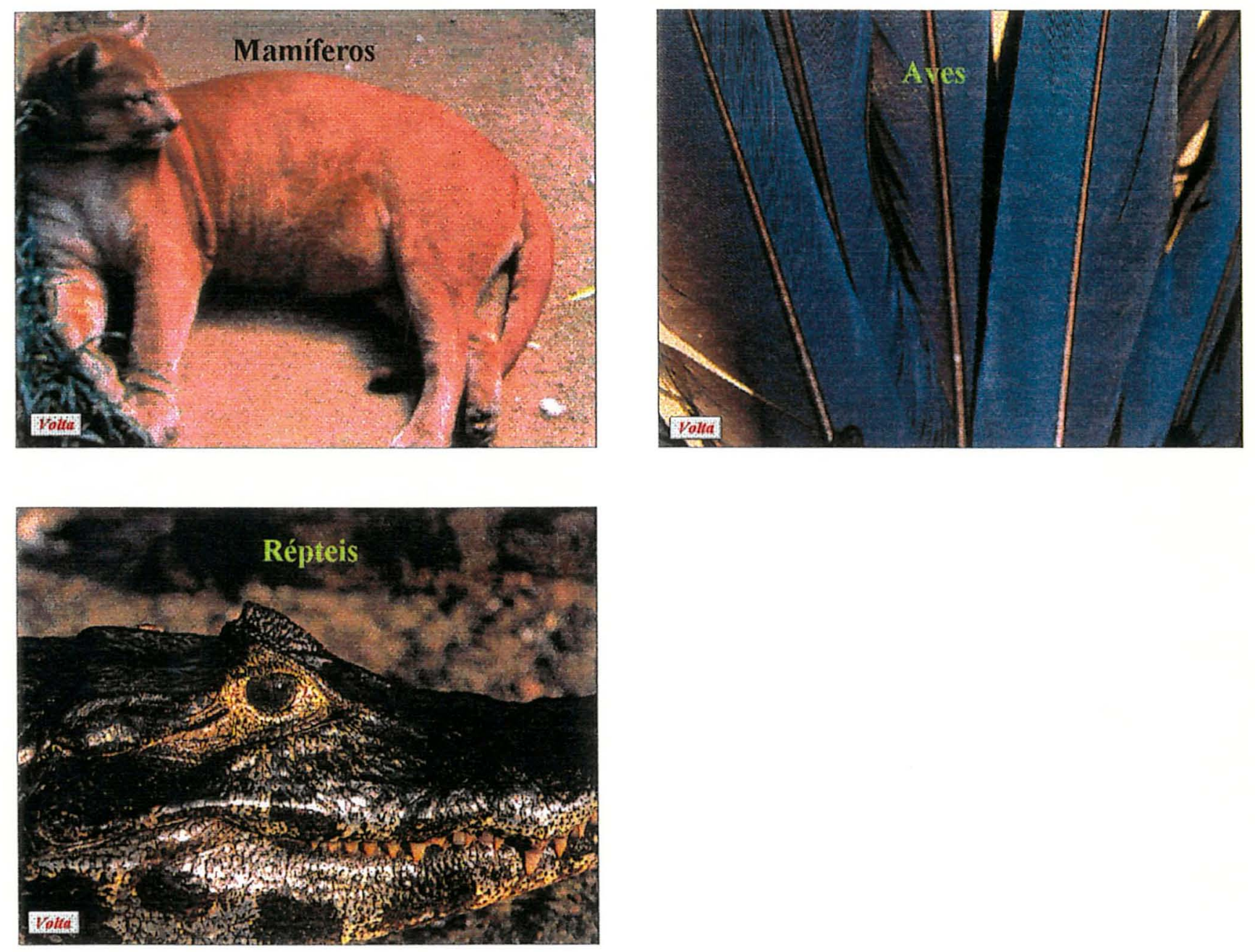


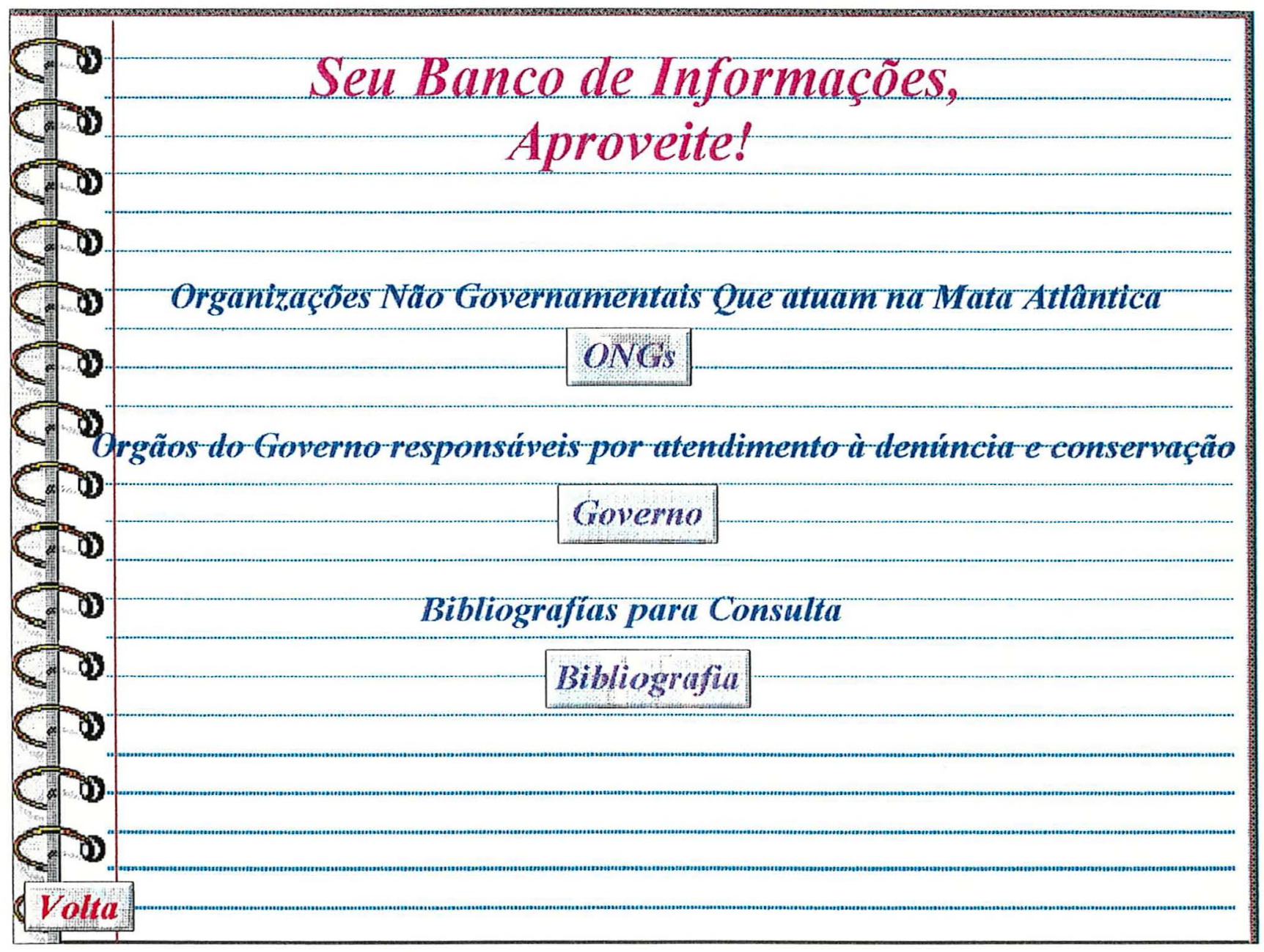



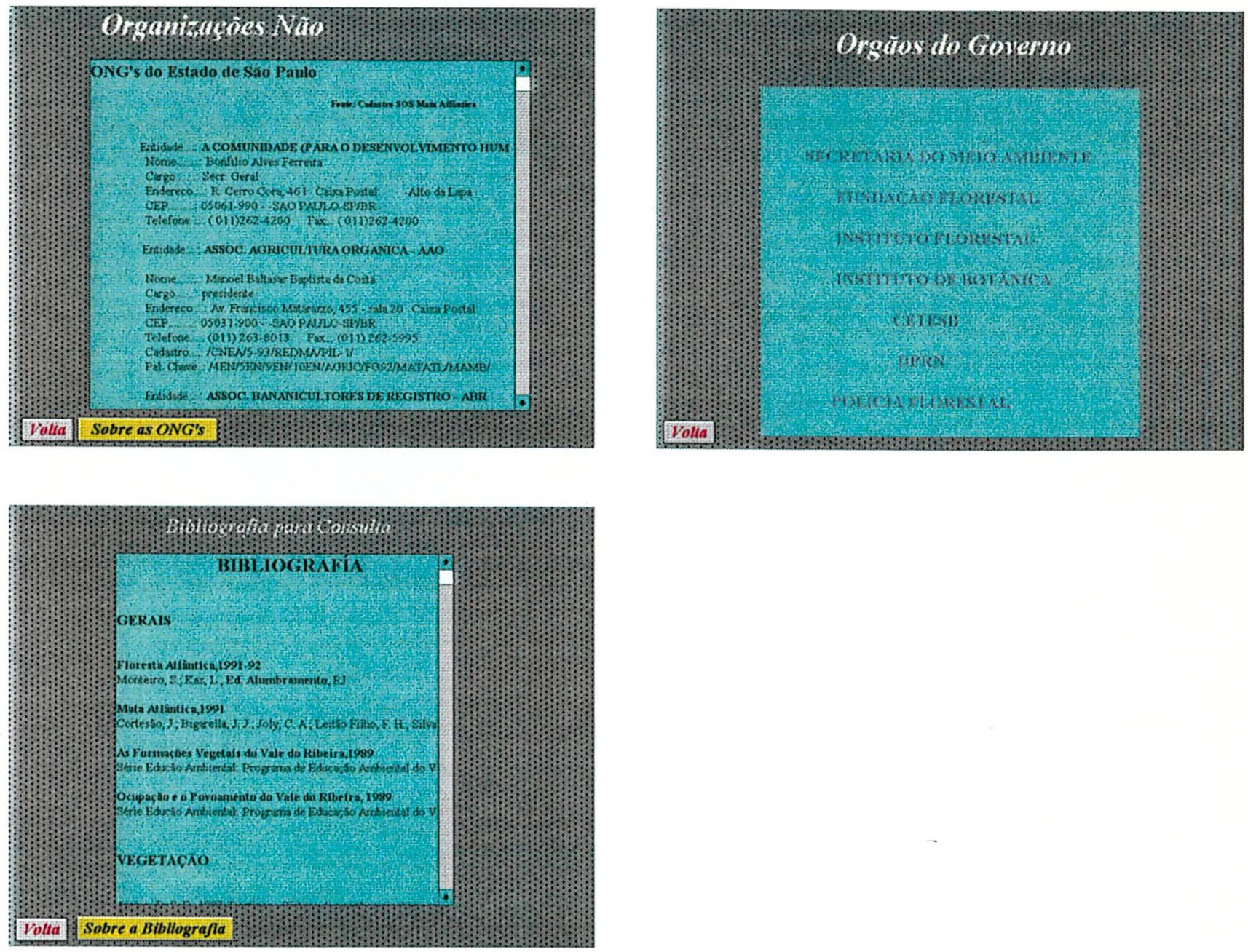
ANEXO C

\section{ELEMENTOS DO DESAFIO}




\section{ELEMENTOS DO DESAFIO (RELEVO, MAR E RIO)}

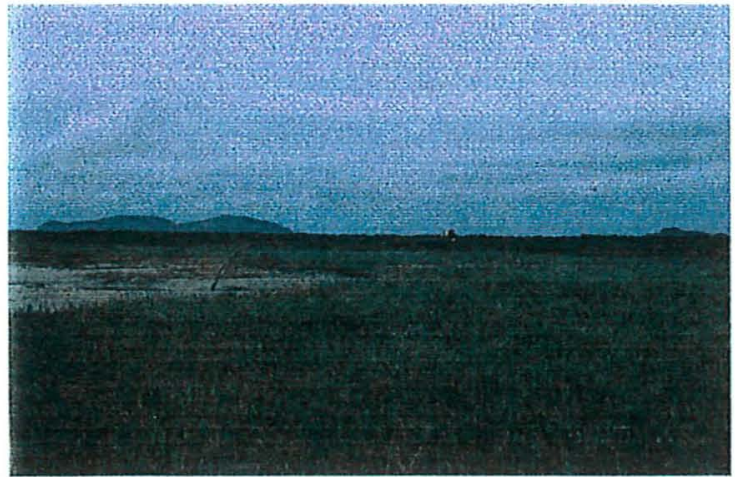

Relevo plano

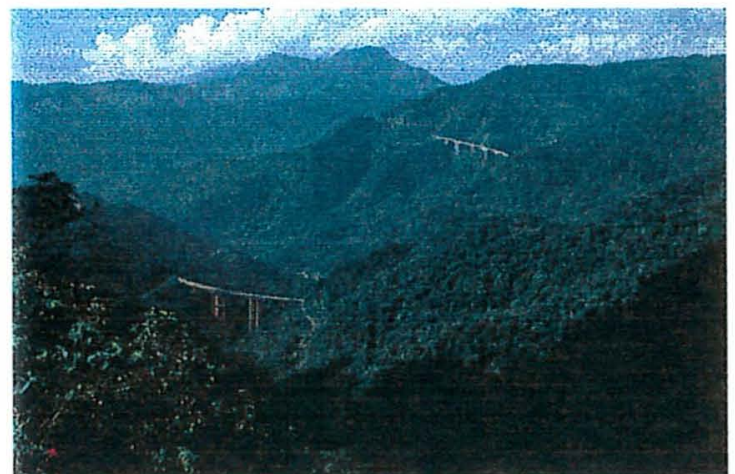

Relevo acidentado

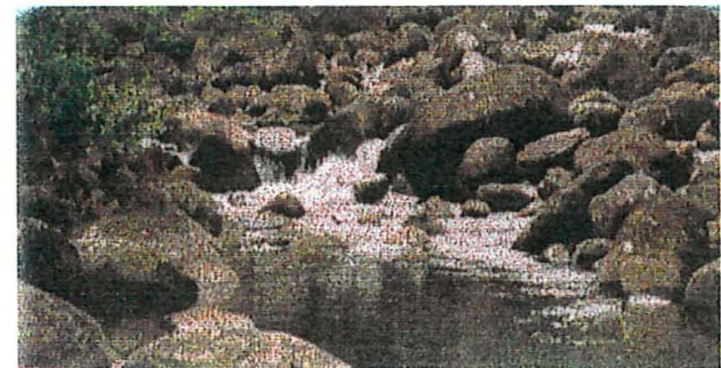

Rio de área montanhosa

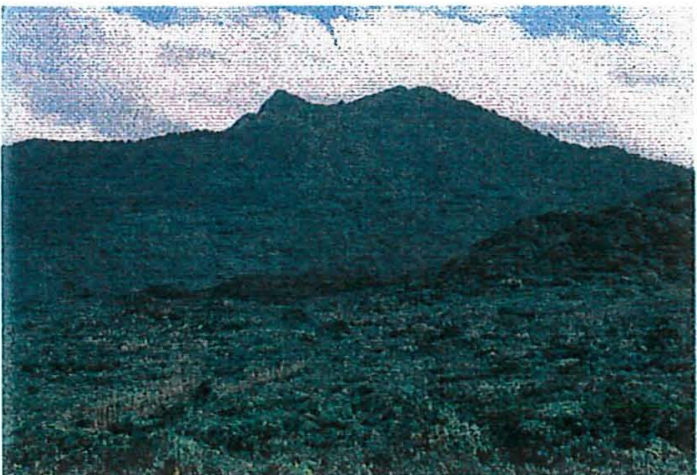

Relevo em transição de plano para acidentado

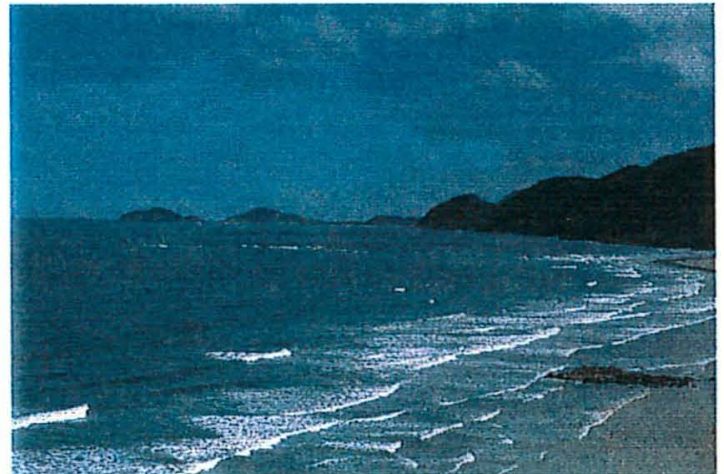

Mar

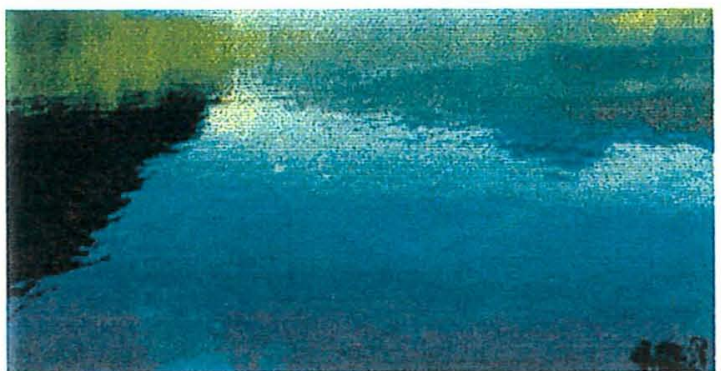

Rio de área plana 


\section{ELEMENTOS DO DESAFIO \\ (VEGETAÇÃO)}

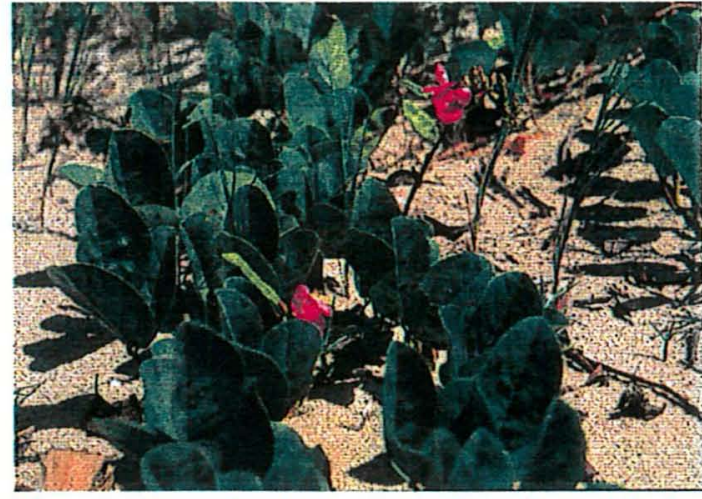

Vegetação: rasteira com baixa diversidade

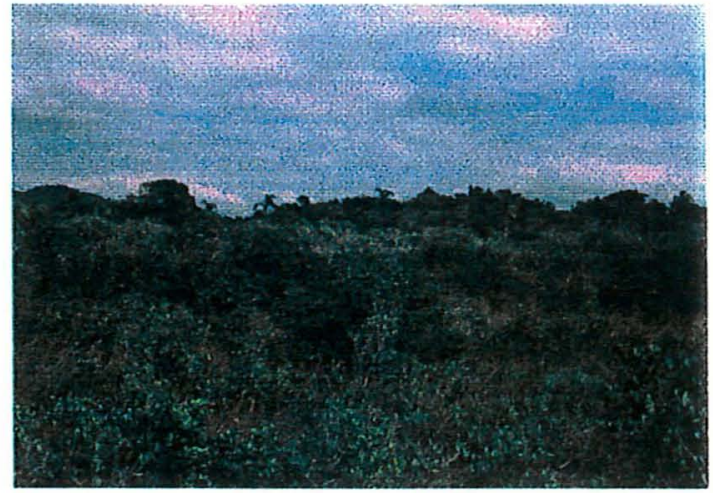

Vegetação: arbustiva de baixo porte com média diversidade

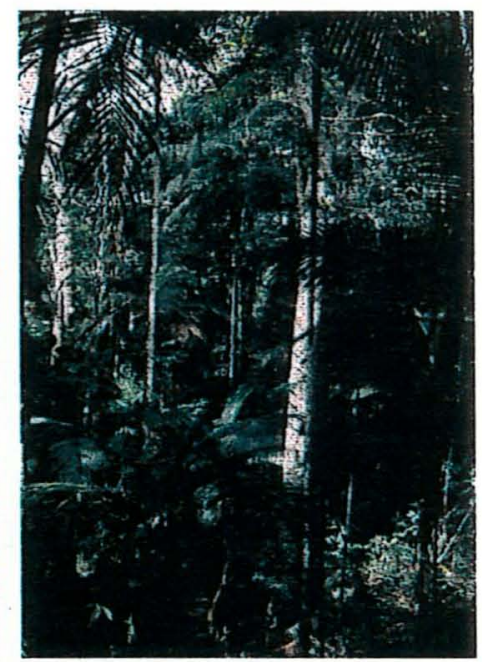

Vegetação: arbórea de grande porte, com alta diversidade
Vegetação: arbustiva e arbórea de médio

porte, com alta diversidade

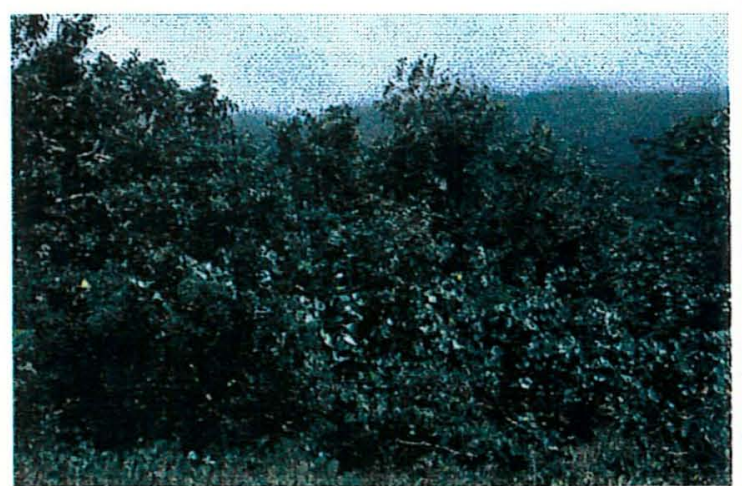

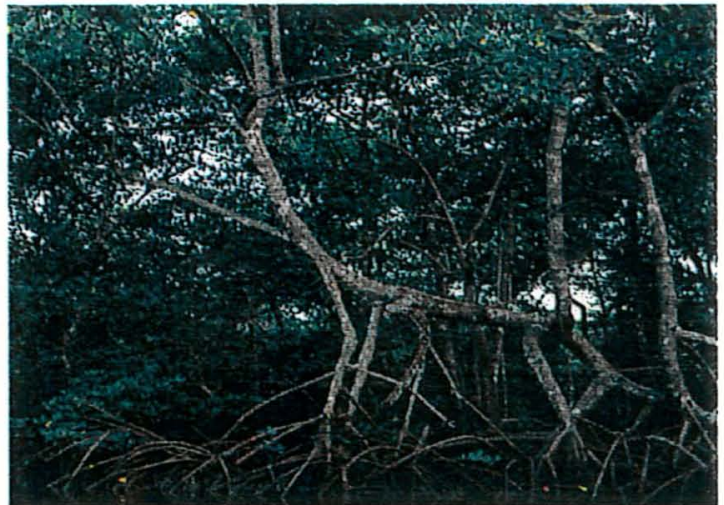

Vegetação: arbórea de médio porte, com baixa diversidade 


\section{ELEMENTOS DO DESAFIO \\ (SOLO)}

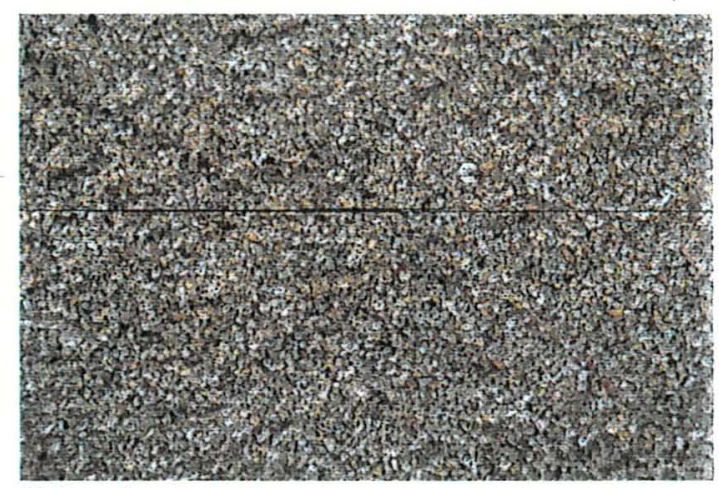

Solo: Areia

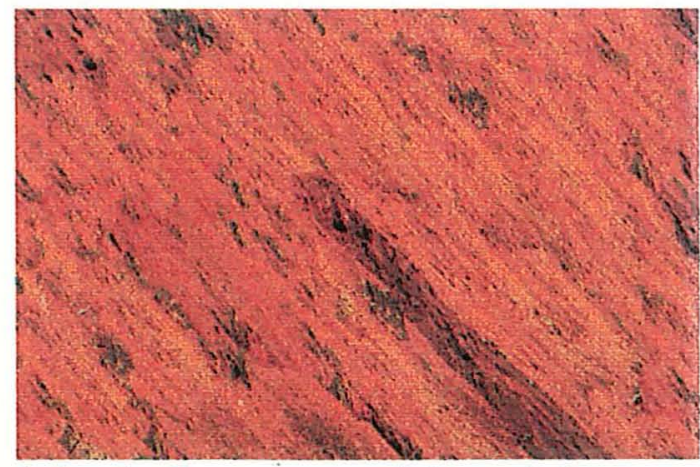

Solo: Argiloso com matéria orgânica

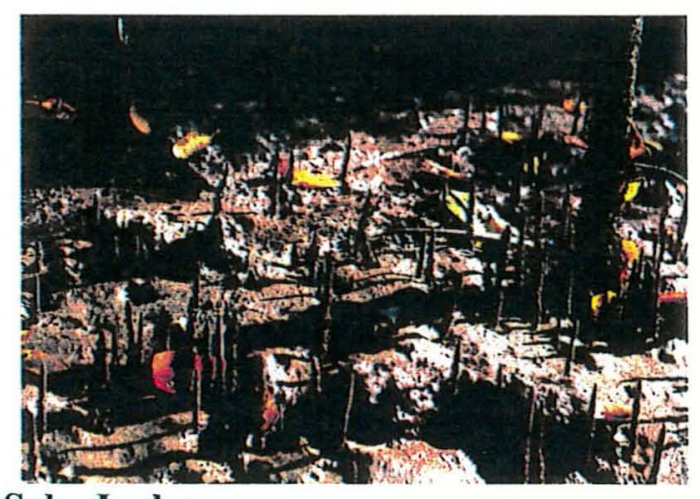

Solo: Lodoso

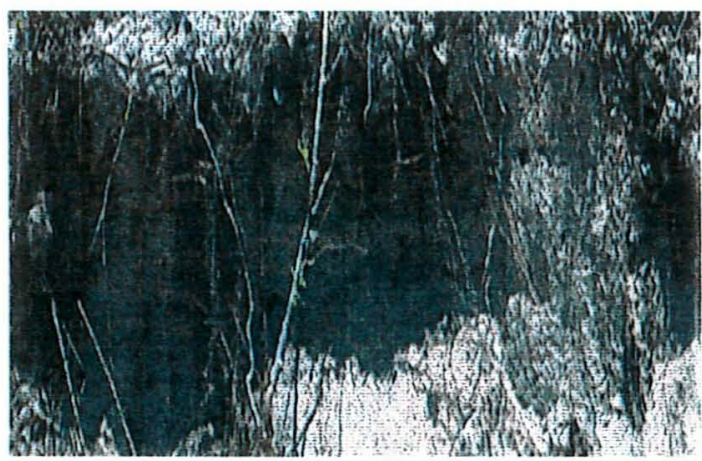

Solo: Arenoso com matéria orgânica 